\title{
Role of centralized review processes for making reimbursement decisions on new health technologies in Europe
}

This article was published in the following Dove Press journal:

ClinicoEconomics and Outcomes Research

29 August 2011

Number of times this article has been viewed

\section{Tania Stafinski' \\ Devidas Menon ${ }^{2}$ \\ Caroline Davis' \\ Christopher $\mathrm{McCabe}^{3}$}

'Health Technology and Policy Unit, ${ }^{2}$ Health Policy and Management, School of Public Health, University of Alberta, Edmonton, Alberta, Canada; ${ }^{3}$ Academic Unit of Health Economics, Leeds Institute for Health Sciences, University of Leeds, Leeds, UK
Correspondence: Tania Stafinski Health Technology and Policy Unit, School of Public Health, University of Alberta, Edmonton, Alberta, Canada T6G 2V2

$\mathrm{Tel}+\mathrm{I} 780492479$ I

Fax + I 780248 I527

Email tanias@ualberta.ca
Background: The purpose of this study was to compare centralized reimbursement/coverage decision-making processes for health technologies in 23 European countries, according to: mandate, authority, structure, and policy options; mechanisms for identifying, selecting, and evaluating technologies; clinical and economic evidence expectations; committee composition, procedures, and factors considered; available conditional reimbursement options for promising new technologies; and the manufacturers' roles in the process.

Methods: A comprehensive review of publicly available information from peer-reviewed literature (using a variety of bibliographic databases) and gray literature (eg, working papers, committee reports, presentations, and government documents) was conducted. Policy experts in each of the 23 countries were also contacted. All information collected was reviewed by two independent researchers.

Results: Most European countries have established centralized reimbursement systems for making decisions on health technologies. However, the scope of technologies considered, as well as processes for identifying, selecting, and reviewing them varies. All systems include an assessment of clinical evidence, compiled in accordance with their own guidelines or internationally recognized published ones. In addition, most systems require an economic evaluation. The quality of such information is typically assessed by content and methodological experts. Committees responsible for formulating recommendations or decisions are multidisciplinary. While criteria used by committees appear transparent, how they are operationalized during deliberations remains unclear. Increasingly, reimbursement systems are expressing interest in and/or implementing reimbursement policy options that extend beyond the traditional "yes," "no," or "yes with restrictions" options. Such options typically require greater involvement of manufacturers which, to date, has been limited.

Conclusion: Centralized reimbursement systems have become an important policy tool in many European countries. Nevertheless, there remains a lack of transparency around critical elements, such as how multiple factors or criteria are weighed during committee deliberations.

Keywords: reimbursement, centralized review, health technologies, Europe

\section{Introduction}

The past decade has seen unprecedented growth in the number of new, often high-cost, health technologies and consumer demand for access to them. It has also seen increased public awareness and scrutiny of decisions about which technologies to include in the basket of publicly insured services. ${ }^{1-3}$ To improve the legitimacy of such decisions and optimize health outcomes through the effective use of increasingly strained health care resources, many payers, particularly those in Europe, have established centralized systems for determining the reimbursement status of new health technologies. ${ }^{4,5}$ 
In this invited review, we compare these systems across selected countries in Northern, Southern, Western, Eastern, and Central Europe, examining:

- Their mandate, authority, organizational structure, and policy options

- Mechanisms for identifying, selecting, and evaluating technologies

- Clinical and economic evidence expectations

- Review committee composition, procedures, and key factors considered during deliberations

- Use of conditional reimbursement options for enabling access to promising new technologies around which considerable uncertainty related to clinical and/or economic value exists

- The role of manufacturers in steps comprising the reimbursement review process.

\section{Methods}

This review is based upon findings from a comprehensive search for publicly available information on centralized reimbursement systems in selected European countries. Peer-reviewed literature published in English over the past decade (ending in January 2011) was located using a structured search strategy that combined relevant controlled vocabulary terms, ie, MeSH and EMTREE (eg, "technology, medical," "reimbursement mechanisms," "decision-making," "technology assessment," "health policy") and free text terms (eg, "pharmaceuticals," "medical devices," "coverage," "funding," "centralized review," "health technology assessment," and "reimbursement," the full search strategy being available from the authors). Such terms were identified through an analysis of words used to index references familiar to the authors. The strategy was applied to several health-related electronic bibliographic databases, including PubMed, MEDLINE, EMBASE, HealthSTAR, CINAHL, EconLit, PASCAL, SCOPUS, International Pharmaceutical Abstracts, Web of Science, and the UK Centre for Reviews and Dissemination databases (Database of Abstracts of Reviews of Effects, National Health Service Economic Evaluation Database, and Health Technology Assessment). For comprehensiveness, reference lists of retrieved papers and the most recent issues of health policy-related journals were hand-searched.

A search for gray (unpublished) literature (eg, working papers, conference abstracts, reports, presentations, government documents) was also performed using the Google $^{\circledR}$ search engine and terms from the main search strategy. In addition, the following dedicated gray literature databases were scanned: the New York Academy of Medicine's Gray Literature database, Knowledge Utilization database, Systematic Reviews for Management and Policy Making, and National Health Service Evidence in Health and Social Care. Separate searches for information on centralized reimbursement processes within health care systems of the top 30 European countries ranked according to gross domestic product per capita by the World Bank were also conducted. This number was considered sufficient to capture the full spectrum of such processes. For each country, the websites of relevant ministries (eg, health, social affairs, economics), translated into English with Google Translate ${ }^{\circledR}$, were scanned for documents describing legislation and other policies and processes for making reimbursement decisions on new health technologies, including pharmaceuticals, medical devices, diagnostic tests, and procedures.

Documents retrieved from the various searches were reviewed independently by two of the authors. Published papers unrelated to the introduction of individual health technologies (eg, those on macrolevel priority setting) were excluded. Because the purpose of this review was to examine current actual processes, papers proposing specific decisionmaking tools or discussing one component of decisionmaking were also excluded. Information on process-related characteristics of the centralized reimbursement systems, including perceived strengths and weaknesses, was extracted using a standardized, pretested data abstraction form. To ensure it reflected the current policy environment, the following individuals were consulted: corresponding authors of published papers, contacts listed on organizations' websites, and European policy experts with whom the authors were already acquainted.

Extracted information was tabulated to facilitate the identification of patterns or trends across country-specific reimbursement processes, and subsequently analyzed qualitatively using content analysis and constant comparison techniques.

\section{Results}

Of the 30 European countries initially identified for the review, information on centralized reimbursement processes could only be found for 23 . Therefore, the review included the following 23 countries: Austria, Belgium, Czech Republic, Denmark, Estonia, Finland, France, Germany, Greece, Hungary, Ireland, Italy, Norway, Poland, Portugal, Scotland, Slovakia, Spain, Sweden, Switzerland, the Netherlands, the United Kingdom, and Wales. 


\section{Mandate of centralized reimbursement systems}

The majority (18/23) of countries have established centralized reimbursement processes to support coverage decisionmaking for either pharmaceuticals or pharmaceuticals and devices needed for their delivery. In general, eligible pharmaceuticals comprise those requiring a prescription. Twothirds of such processes review both inpatient and outpatient pharmaceuticals (12/18), while one-third (6/18) considers those administered in outpatient settings only (Table 1). The remaining five countries have invested in centralized reimbursement systems that span medical devices, procedures, and pharmaceuticals (Table 1). Despite differences in the scope of technologies included, such processes share a similar mandate to determine the reimbursement status of new technologies. In most of the countries, this amounts to a decision on whether to add the technology to a "positive list" (ie, list of insured services). However, a small proportion of the countries also maintain a "negative list" (ie, a list of nonreimbursable services), broadening the mandate of their centralized reimbursement systems to include decisions resulting in active exclusion of some technologies from the benefit plan (Table 1). In legislation governing most systems (13/23), decisions are authoritative (ie, must be implemented), rather than advisory (ie, recommendations). Given that the price of a technology can significantly influence assessments of value for money and affordability, many of the countries have also incorporated pricing into the mandates of such systems (discussed in detail later). Finally, all consider at least three funding decision options, ie, provide, do not provide, and provide with restrictions or conditions (ie, restrict use to specific providers or patients meeting certain criteria, Table 1). In addition, approximately one-third have introduced a fourth option, ie, provide while additional evidence is collected. The latter comprises a provisional funding arrangement in which the technology is reimbursed in the interim while information needed to reduce uncertainties in existing evidence is collected to support a definitive decision.

\section{Assessment of health technologies in centralized reimbursement systems}

Approaches to the identification of technologies for review by centralized reimbursement systems vary across countries (Table 2). Broadly, there are three strategies: technologies may be submitted by manufacturers seeking coverage for newly licensed pharmaceuticals (13/23); they may be referred by potential payers (eg, government, sickness funds) or users (eg, hospitals, providers, patients), as well as manufacturers $(8 / 23)$; or they may be identified by payers or users only $(2 / 23)$. Systems limited to consideration of reimbursement applications from manufacturers alone typically review submissions in order of receipt, unless a technology is eligible for "fast tracking," which moves it to the front of the queue. In countries with such mechanisms (eg, the Netherlands), eligibility criteria include technologies (mainly pharmaceuticals) used to treat rare or life-threatening conditions for which no alternatives beyond best supportive care exist. Some countries (eg, Scotland and Norway) have more closely linked centralized regulatory and reimbursement processes in order to reduce overall inefficiencies in technology policy. Specifically, pharmaceuticals are automatically sent to the centralized reimbursement system for review upon market approval. In systems that accept referrals from multiple stakeholders, technology selection and/or prioritization criteria have been established. For example, Germany's Federal Joint Committee, which determines which technologies to review, takes into account clinical relevance, cost implications, and potential "risks" related to the technology and its introduction into the health care system. ${ }^{6}$ In the UK, the topic selection panel of the National Institute of Health and Clinical Excellence, whose members include health care providers and patient representatives, formulate recommendations following consideration of: the burden of disease for which the technology targets; anticipated clinical impact (ie, whether the technology represents a significant medical advance that could yield substantial health benefits); potential impact on National Health Service costs and resources; alignment of the technology with broader government priority areas; concerns over appropriateness of use in practice; and potential for national guidance to add value. ${ }^{7}$ Recommendations are forwarded to the Department of Health, which makes the final decision.

Across centralized reimbursement systems, technology identification and selection is followed by some form of health technology assessment (Table 2). This involves collection and synthesis of evidence (clinical and, in most cases, economic), the findings of which are presented in an assessment report, and critical appraisal of the relevance, quality, and generalizability of that evidence. The results of the latter are summarized in an evaluation report. Responsibility for the preparation of these reports varies. In systems where a manufacturer's submission initiates the reimbursement review process, the assessment report is part of the submission (Table 2). Therefore, its preparation rests with the 
Table I Centralized reimbursement system and mandate

\begin{tabular}{|c|c|c|c|}
\hline Country & $\begin{array}{l}\text { Centralized reimbursement } \\
\text { review/decision-making body (role) }\end{array}$ & Technology scope & Decision problem \\
\hline Austria & $\begin{array}{l}\text { - Association of Austrian Social } \\
\text { Security Institutions (decisions) }{ }^{55} \\
\text { - Pharmaceutical Evaluation Board/ } \\
\text { Austrian Medicines Evaluation } \\
\text { Commission (recommendations) }\end{array}$ & $\begin{array}{l}\text { - Pharmaceuticals } \\
\text { - Outpatient }{ }^{55}\end{array}$ & $\begin{array}{l}\text { - Provide as publicly insured } \\
\text { service (reimbursable) } \\
\text { - Do not provide as publicly } \\
\text { insured service (nonreimbursable) }\end{array}$ \\
\hline Belgium & $\begin{array}{l}\text { - Minister of Social Affairs (decisions) } \\
\text { - Commission on reimbursement } \\
\text { of medicines/Drug Reimbursement } \\
\text { Committee (recommendations) }\end{array}$ & $\begin{array}{l}\text { - Pharmaceuticals } \\
\text { - Outpatient } \\
\text { - Inpatient }{ }^{21,64}\end{array}$ & $\begin{array}{l}\text { - Provide as publicly insured } \\
\text { service (reimbursable) }{ }^{21}\end{array}$ \\
\hline Czech Republic & $\begin{array}{l}\text { State Institute for Drug } \\
\text { Control (decisions) }{ }^{65-67}\end{array}$ & $\begin{array}{l}\text { - Pharmaceuticals } \\
\text { - Outpatient }{ }^{65}\end{array}$ & $\begin{array}{l}\text { - Provide as publicly insured } \\
\text { service (reimbursable) }\end{array}$ \\
\hline Denmark & $\begin{array}{l}\text { - Danish Medicines Agency } \\
\text { (decisions). }{ }^{68-70} \text { Reimbursement } \\
\text { Committee (recommendations) }{ }^{68,70}\end{array}$ & $\begin{array}{l}\text { - Pharmaceuticals } \\
\text { - Outpatient }{ }^{71}\end{array}$ & $\begin{array}{l}\text { - Provide as publicly } \\
\text { insured service }{ }^{38,46,69,71}\end{array}$ \\
\hline Estonia & $\begin{array}{l}\text { - Ministry of Social Affairs (decisions) })^{72} \\
\text { - Pharmaceuticals Committee } \\
\text { (recommendations) }^{72}\end{array}$ & $\begin{array}{l}\text { - Pharmaceuticals } \\
\text { - Outpatient }{ }^{72}\end{array}$ & $\begin{array}{l}\text { - Provide as publicly } \\
\text { insured service (reimbursable) }{ }^{72}\end{array}$ \\
\hline Finland & $\begin{array}{l}\text { - Pharmaceuticals Pricing } \\
\text { Board (decisions) } \text { - }^{64,73,74} \\
\text { Pharmaceuticals Pricing Board } \\
\text { Expert Group (recommendations) }\end{array}$ & $\begin{array}{l}\text { - Pharmaceuticals } \\
\text { - Outpatient }{ }^{76}\end{array}$ & $\begin{array}{l}\text { - Provide as publicly insured } \\
\text { service (reimbursable) }{ }^{76} \\
\text { - Do not provide as publicly } \\
\text { funded service (nonreimbursable) }{ }^{76}\end{array}$ \\
\hline France & $\begin{array}{l}\text { - Ministry for Health and } \\
\text { Social Security (decisions) })^{20,78} \\
\text { - French National Authority } \\
\text { for Health (recommendations) }\end{array}$ & $\begin{array}{l}\text { - Pharmaceuticals } \\
\text { - Outpatient } \\
\text { - Inpatient }{ }^{79} \\
\text { - Devices }{ }^{79} \\
\text { - } \text { Procedures }^{79}\end{array}$ & $\begin{array}{l}\text { - Provide as publicly insured } \\
\text { service (reimbursable) }{ }^{80}\end{array}$ \\
\hline Germany & $\begin{array}{l}\text { - Federal Joint Committee } \\
\text { (decisions) })^{19} \\
\text { - Institute for Quality and Efficiency } \\
\text { in Health Care (recommendations) }{ }^{19}\end{array}$ & $\begin{array}{l}\text { - Pharmaceuticals } \\
\text { - Outpatient } \\
\text { - Inpatient }{ }^{81,82} \\
\text { - Devices } \\
\text { - } \text { Procedures }^{83}\end{array}$ & $\begin{array}{l}\text { - Provide as publicly insured } \\
\text { service (reimbursable) }{ }^{55} \\
\text { - Do not provide as publicly } \\
\text { funded service (nonreimbursable) }{ }^{55} \\
\text { Note: Must not exclude technologies } \\
\text { for which there is no alternative }{ }^{18,81}\end{array}$ \\
\hline Greece & $\begin{array}{l}\text { - Transparency Committee in } \\
\text { the Reimbursement and Medicinal } \\
\text { Products (makes decisions) }\end{array}$ & $\begin{array}{l}\text { - Pharmaceuticals } \\
\text { - Outpatient }{ }^{85}\end{array}$ & $\begin{array}{l}\text { - Classify pharmaceutical } \\
\text { into therapeutic category }\end{array}$ \\
\hline Hungary & $\begin{array}{l}\text { - Ministers of Health and Finance (decisions) } \\
\text { - National Health Insurance Fund } \\
\text { Administration Health Technology } \\
\text { Assessment Committee (recommendations) }{ }^{88,89}\end{array}$ & $\begin{array}{l}\text { - Pharmaceuticals } \\
\text { - Outpatient } \\
\text { - Inpatient }\end{array}$ & $\begin{array}{l}\text { - Provide as publicly insured service }{ }^{88} \\
\text { - Do not provide as publicly } \\
\text { funded service (nonreimbursable) }{ }^{26}\end{array}$ \\
\hline Ireland & - Health Service Executive (decisions) ${ }^{91,92}$ & $\begin{array}{l}\text { - Pharmaceuticals } \\
\text { - Outpatient } \\
\text { - Inpatient } \\
\text { - Devices } \\
\text { - Procedures }\end{array}$ & $\begin{array}{l}\text { - Provide as publicly insured } \\
\text { service (reimbursable) }{ }^{92}\end{array}$ \\
\hline Italy & $\begin{array}{l}\text { - Italian Medicines Agency Technical } \\
\text { Scientific Committee (decisions) } \\
\text { - Italian Medicines Agency Pricing and } \\
\text { Reimbursement Committee } \\
\text { (recommendations) }^{95}\end{array}$ & $\begin{array}{l}\text { - Pharmaceuticals } \\
\text { - Outpatient } \\
\text { - Inpatient }{ }^{21}\end{array}$ & $\begin{array}{l}\text { - Provide as publicly insured } \\
\text { service (reimbursable) })^{21}\end{array}$ \\
\hline Norway & $\begin{array}{l}\text { - Norwegian Medicines Agency (decisions) } \\
\text { - Department of Pharmacoeconomics } \\
\text { (recommendations) }^{98}\end{array}$ & $\begin{array}{l}\text { - Pharmaceuticals } \\
\text { - Outpatient } \\
\text { - Inpatient }{ }^{34}\end{array}$ & $\begin{array}{l}\text { - Provide as publicly insured } \\
\text { service (reimbursable) }\end{array}$ \\
\hline
\end{tabular}




\begin{tabular}{|c|c|c|c|c|c|}
\hline \multicolumn{2}{|l|}{ Decision “scope” } & \multicolumn{4}{|c|}{ Available decision options } \\
\hline Reimbursement & Linkage to pricing & Provide & Do not provide & Provide with restrictions & $\begin{array}{l}\text { Provide while additional } \\
\text { evidence is collected }\end{array}$ \\
\hline$Y_{e s}^{56,59}$ & $Y_{e s}^{21,56,59}$ & $Y_{e s}^{56}$ & $Y_{e s}^{56}$ & Yes $^{56}$ & Not specified \\
\hline Yes $^{21}$ & Yes $^{21}$ & Yes $^{21}$ & $Y_{e s}{ }^{21}$ & $Y_{e s}^{21}$ & $Y_{e s}{ }^{21}$ \\
\hline$Y_{e s}^{67}$ & $Y_{e s}^{67}$ & Yes $^{65}$ & $Y_{e s}^{65}$ & Yes $^{65}$ & Not specified \\
\hline Yes $^{68}$ & $\mathrm{No}^{68}$ & Yes $^{38,69}$ & Yes $^{38,69}$ & $Y_{e s}^{38,69}$ & Not specified \\
\hline Yes $^{72}$ & Yes $^{72}$ & Yes $^{72}$ & Yes $^{72}$ & Yes $^{72}$ & $\mathrm{No}^{67}$ \\
\hline Yes $^{76}$ & Yes $^{76}$ & Yes $^{77}$ & Yes $^{73}$ & Yes $^{73}$ & $\mathrm{No}^{74}$ \\
\hline Yes $^{16,20,22,78}$ & Yes $^{16,20,22,78}$ & $Y_{e s}^{20}$ & $Y_{e s}{ }^{20}$ & $\mathrm{Yes}^{20}$ & Yes $^{16,20}$ \\
\hline$Y_{e s}^{19}$ & $Y_{e s}^{82,84}$ & Yes $^{19}$ & Yes $^{19}$ & Yes $^{19}$ & Yes $^{19}$ \\
\hline Yes $^{85}$ & $Y_{e s}^{87}$ & N/A & N/A & $\mathrm{N} / \mathrm{A}$ & N/A \\
\hline$Y_{e s}^{88}$ & Not specified & Yes $^{90}$ & Yes $^{90}$ & $Y_{e s}{ }^{90}$ & Not specified \\
\hline$Y_{e s}^{91}$ & No91 & Yes $^{91}$ & Yes ${ }^{91}$ & Yes' & $\mathrm{No}^{93}$ \\
\hline Yes ${ }^{96,97}$ & Yes 96,97 & Yes $^{96}$ & Yes $^{96}$ & Yes ${ }^{96}$ & Yes $^{96}$ \\
\hline Yes $^{98}$ & Yes $^{98}$ & Yes $^{98}$ & Yes $^{98}$ & Yes $^{98}$ & Not specified \\
\hline
\end{tabular}


Table I (Continued)

\begin{tabular}{|c|c|c|c|}
\hline Country & $\begin{array}{l}\text { Centralized reimbursement } \\
\text { review/decision-making body (role) }\end{array}$ & Technology scope & Decision problem \\
\hline Poland & - Ministry of Health (decisions) ${ }^{99}$ & $\begin{array}{l}\text { - Pharmaceuticals } \\
\text { - Outpatient } \\
\text { - Inpatient }\end{array}$ & $\begin{array}{l}\text { - Provide as publicly insured } \\
\text { service (reimbursable) }{ }^{100}\end{array}$ \\
\hline Portugal & $\begin{array}{l}\text { - Ministry of Health (decisions) } \\
\text { - INFARMED (recommendations) }{ }^{44,101}\end{array}$ & $\begin{array}{l}\text { - Pharmaceuticals } \\
\text { - Outpatient } \\
\text { - Inpatient }{ }^{102}\end{array}$ & $\begin{array}{l}\text { - Provide as publicly } \\
\text { insured service (reimbursable) }{ }^{44}\end{array}$ \\
\hline Scotland & $\begin{array}{l}\text { - National Health Service Scotland (decisions) }{ }^{30} \\
\text { - Scottish Medicines Consortium } \\
\text { (recommendations) }\end{array}$ & $\begin{array}{l}\text { - Pharmaceuticals } \\
\text { - Outpatient } \\
\text { - Inpatient }{ }^{30}\end{array}$ & $\begin{array}{l}\text { - Provide as publicly insured } \\
\text { service (reimbursable) }{ }^{30}\end{array}$ \\
\hline Slovakia & $\begin{array}{l}\text { - Ministry of Health (decisions) } \\
\text { - Reimbursement Committee for } \\
\text { Medicinal Products (recommendations) }\end{array}$ & $\begin{array}{l}\text { - Pharmaceuticals } \\
\text { - Outpatient } \\
\text { - Inpatient }\end{array}$ & $\begin{array}{l}\text { - Provide as publicly } \\
\text { insured service (reimbursable) }{ }^{102} \\
\text { - Do not provide as publicly } \\
\text { funded service (nonreimbursable) })^{102}\end{array}$ \\
\hline Spain & $\begin{array}{l}\text { - Ministry of Health Directorate } \\
\text { General of Pharmacy and Health } \\
\text { Products (decisions) }\end{array}$ & $\begin{array}{l}\text { - Pharmaceuticals } \\
\text { - Outpatient } \\
\text { - Inpatient }\end{array}$ & $\begin{array}{l}\text { - Provide as publicly funded } \\
\text { service (reimbursable) }{ }^{108} \\
\text { - Do not provide as publicly } \\
\text { funded service (non-reimbursable) }{ }^{108}\end{array}$ \\
\hline Sweden & $\begin{array}{l}\text { - Dental and Pharmaceutical } \\
\text { Benefits Board (decisions) }{ }^{15,109,110}\end{array}$ & $\begin{array}{l}\text { - Pharmaceuticals } \\
\text { - Outpatient } \\
\text { - Devices (for administration } \\
\text { of pharmaceuticals) } \text { ) }^{15,21,33,109}\end{array}$ & $\begin{array}{l}\text { - Provide as publicly } \\
\text { funded service (reimbursable) }{ }^{15}\end{array}$ \\
\hline Switzerland & $\begin{array}{l}\text { - Swiss Federal Office of Public } \\
\text { Health (decisions) } \\
\text { - Federal Drug Commission } \\
\text { (recommendations) }{ }^{1 / 3-115}\end{array}$ & $\begin{array}{l}\text { - Pharmaceuticals } \\
\text { - Outpatient } \\
\text { - Inpatient }\end{array}$ & $\begin{array}{l}\text { - Provide as publicly funded } \\
\text { service (reimbursable) }\end{array}$ \\
\hline The Netherlands & $\begin{array}{l}\text { - Ministry of Health, Welfare and } \\
\text { Sport (decisions) } \\
\text { - Medicinal Products Reimbursement } \\
\text { Committee of the Dutch Healthcare } \\
\text { Insurance Board (recommendations) }\end{array}$ & $\begin{array}{l}\text { - Pharmaceuticals } \\
\text { - Outpatient } \\
\text { - High cost } \\
\text { Inpatient }^{49} \\
\text { - Procedures }\end{array}$ & $\begin{array}{l}\text { - Provide as publicly funded } \\
\text { service (reimbursable) }{ }^{49}\end{array}$ \\
\hline United Kingdom & $\begin{array}{l}\text { - National Institute for Health and } \\
\text { Clinical Excellence (decisions) } \\
\text { - Technology Appraisals } \\
\text { Committee (recommendations) }{ }^{7}\end{array}$ & $\begin{array}{l}\text { - Pharmaceuticals } \\
\text { - Outpatient } \\
\text { - Inpatient }{ }^{7} \\
\text { - Devices } \\
\text { - } \text { Procedures }^{7}\end{array}$ & $\begin{array}{l}\text { - Provide as publicly } \\
\text { funded service (reimbursable) }{ }^{7}\end{array}$ \\
\hline Wales & $\begin{array}{l}\text { - Ministry for Health and } \\
\text { Social Services (decisions) } \\
\text { - All Wales Medicines Strategy } \\
\text { Group (recommendations) }\end{array}$ & $\begin{array}{l}\text { - Pharmaceuticals } \\
\text { - Outpatient } \\
\text { - Inpatient }\end{array}$ & $\begin{array}{l}\text { - Provide as publicly funded service } \\
\text { (reimbursable) }^{120}\end{array}$ \\
\hline
\end{tabular}

manufacturer. Most systems have developed a standard template/structure for the report and submission guidelines to which manufacturers must adhere. These guidelines largely include content/information requirements and internationally accepted methods for synthesizing and analyzing evidence. In two of the countries, responsibility for the assessment depends upon the type of review ("appraisal"). Both France and the UK have created "single technology appraisal" and "multiple technology appraisal" processes. "Single technology appraisals" compare the candidate technology with a limited number of alternatives for a specific, well-defined indication (eg, disease stage). Their scope most closely resembles processes based upon manufacturers' submissions. "Multiple technology appraisals" consider either several indications for a candidate technology or several technologies (along with the candidate technology) for a condition at one or more points in its course, taking a disease management approach. The assessment report for a single technology appraisal is prepared by the manufacturer. For a multiple technology appraisal, the report is drafted either internally with support 


\begin{tabular}{|c|c|c|c|c|c|}
\hline \multicolumn{2}{|l|}{ Decision "scope" } & \multicolumn{4}{|c|}{ Available decision options } \\
\hline Reimbursement & Linkage to pricing & Provide & Do not provide & Provide with restrictions & $\begin{array}{l}\text { Provide while additional } \\
\text { evidence is collected }\end{array}$ \\
\hline$Y_{e s}^{100}$ & Yes $^{100}$ & Yes $^{100}$ & Yes $^{100}$ & $Y_{e s}{ }^{100}$ & Not specified \\
\hline Yes $^{103}$ & Yes 99 & Yes 99 & Yes ${ }^{99}$ & Yes $^{99}$ & No99 \\
\hline$Y_{e s}^{104}$ & $\mathrm{No}^{104}$ & $Y_{e s}{ }^{104}$ & Yes $^{104}$ & Yes ${ }^{99}$ & No99 \\
\hline Yes ${ }^{106}$ & Yes $^{106}$ & Yes $^{102}$ & $Y_{e s}{ }^{102}$ & $Y_{e s}{ }^{102}$ & Not specified \\
\hline$Y_{e s}{ }^{21}$ & $Y^{21}$ & $Y^{21}$ & $Y^{21}$ & $Y^{21}$ & $\mathrm{No}^{21}$ \\
\hline Yes'"I & $Y_{e s}^{112}$ & Yes ${ }^{109}$ & Yes ${ }^{109}$ & $Y_{e s}^{109}$ & Yes ${ }^{109}$ \\
\hline$Y_{e s}^{113,114}$ & Yes $^{113,114}$ & Yes $^{113,114}$ & $Y_{e s^{113,114}}$ & Yes $^{113,114}$ & Not specified \\
\hline$Y_{e s}^{117,118}$ & $\mathrm{No}^{31}$ & $Y_{e s^{31}}$ & $Y_{e s^{31}}$ & $Y_{e}{ }^{119}$ & $Y_{e s} 119$ \\
\hline Yes $^{7}$ & $\mathrm{No}^{7}$ & $\mathrm{Yes}^{7}$ & Yes $^{7}$ & $\mathrm{Yes}^{7}$ & Yes $^{7}$ \\
\hline$Y_{e s}^{120}$ & $\mathrm{No}^{120}$ & $Y_{e s}{ }^{120}$ & $Y_{e s}^{120}$ & $Y_{e s}^{120}$ & $Y_{e s}^{120}$ \\
\hline
\end{tabular}

from external content and methodological experts (France) or by an independent academic group (the UK). Finally, in some countries, technical staff of a dedicated health technology assessment body or the centralized reimbursement system itself undertake the assessment report, regardless of the scope (eg, Germany).

With one exception (the UK), responsibility for preparing the evaluation report that accompanies each assessment also lies with technical staff and, if necessary, external experts. The National Institute of Health and Clinical Excellence commissions independent academic groups to evaluate assessments submitted by manufacturers as part of its single technology appraisal process.

\section{Clinical and economic evidence expectations of centralized reimbursement systems}

Centralized reimbursement systems have issued their own guidelines or endorsed internationally recognized published ones specifying clinical and economic evidence 
Table 2 Comparison of processes for identifying, selecting, and assessing technologies

\begin{tabular}{|c|c|c|}
\hline \multirow[t]{2}{*}{ Country } & \multirow{2}{*}{$\begin{array}{l}\text { Centralized reimbursement review/ } \\
\text { decision-making body (role) }\end{array}$} & \multirow{2}{*}{$\begin{array}{l}\text { Technologies to be considered for review } \\
\text { Technology identification }\end{array}$} \\
\hline & & \\
\hline Austria & $\begin{array}{l}\text { - Association of Austrian Social } \\
\text { Security Institutions (decisions) } \\
\text { - Pharmaceutical Evaluation } \\
\text { Board (recommendations) }\end{array}$ & $\begin{array}{l}\text { Referred by: } \\
\text { - Manufacturers seeking reimbursement for newly approved } \\
\text { pharmaceuticals }^{58}\end{array}$ \\
\hline Belgium & $\begin{array}{l}\text { - Minister of Social Affairs (decisions) } \\
\text { - Commission on reimbursement } \\
\text { of medicines/Drug Reimbursement } \\
\text { Committee (CRM) (recommendations) }\end{array}$ & $\begin{array}{l}\text { Referred by: } \\
\text { - Manufacturers seeking reimbursement } \\
\text { for newly approved pharmaceuticals }{ }^{17}\end{array}$ \\
\hline Czech Republic & $\begin{array}{l}\text { - State Institute for Drug } \\
\text { Control (decisions) }\end{array}$ & $\begin{array}{l}\text { Referred by: } \\
\text { - Manufacturers seeking reimbursement for newly approved } \\
\text { pharmaceuticals }{ }^{66}\end{array}$ \\
\hline Denmark & $\begin{array}{l}\text { - Danish Medicines } \\
\text { Agency (decisions) } \\
\text { - Reimbo, Reimbement Committee } \\
\text { (recommendations) })^{68,121}\end{array}$ & $\begin{array}{l}\text { Referred by: } \\
\text { - Manufacturers seeking reimbursement for newly approved } \\
\text { pharmaceuticals }^{84}\end{array}$ \\
\hline Estonia & $\begin{array}{l}\text { - Ministry of Social Affairs } \\
\text { (decisions })^{72} \\
\text { - Pharmaceuticals Committee } \\
\text { (recommendations })^{72}\end{array}$ & $\begin{array}{l}\text { Referred by: } \\
\text { - Manufacturers seeking reimbursement for newly approved } \\
\text { pharmaceuticals }^{72}\end{array}$ \\
\hline Finland & $\begin{array}{l}\text { - Pharmaceuticals Pricing } \\
\text { Board (decisions) })^{73,74,76} \\
\text { - Pharmaceuticals Pricing Board } \\
\text { Expert Group (recommendations) })^{75}\end{array}$ & $\begin{array}{l}\text { Referred by: } \\
\text { - Manufacturers seeking reimbursement } \\
\text { for newly approved pharmaceuticals }{ }^{76}\end{array}$ \\
\hline France & $\begin{array}{l}\text { - Ministry for Health and } \\
\text { Social Security (decisions) })^{21,78} \\
\text { - French National Authority for } \\
\text { Health (recommendations) }{ }^{78}\end{array}$ & $\begin{array}{l}\text { Depends on type of appraisal } 1^{6,20} \\
\text { Single technology appraisal } \\
\text { Referred by: } \\
\text { - Manufacturers seeking reimbursement for newly approved } \\
\text { pharmaceuticals and devices } \\
\text { - Health care professional associations seeking reimbursement } \\
\text { for procedures } \\
\text { Multiple technology appraisals } \\
\text { Typically classes of pharmaceuticals } \\
\text { or categories of devices } \\
\text { Referred by: } \\
\text { - Health care professional associations } \\
\text { - Ministry of Health } \\
\text { - National Union of Health Insurance Funds } \\
\text { - Patient and/or carer organizations }{ }^{120}\end{array}$ \\
\hline Germany & $\begin{array}{l}\text { - Federal Joint Committee (decisions) })^{19} \\
\text { - Institute for Quality and Efficiency in Health Care } \\
\text { (recommendations) }^{19}\end{array}$ & $\begin{array}{l}\text { Referred by: } \\
\text { - Associations represented by Federal Joint Committee } \\
\text { - Ministry of Health } \\
\text { - Institute for Quality and Efficiency in Health Care } \\
\text { - Federal commissioner of patient affairs } \\
\text { - Patient and/or carer organizations }{ }^{18}\end{array}$ \\
\hline Greece & $\begin{array}{l}\text { - Transparency Committee in the Reimbursement and } \\
\text { Medicinal Products (makes decisions) } \text { s5 }^{25}\end{array}$ & $\begin{array}{l}\text { Referred by: } \\
\text { - Manufacturers seeking reimbursement } \\
\text { for newly approved pharmaceuticals }{ }^{85}\end{array}$ \\
\hline Hungary & $\begin{array}{l}\text { - Ministers of Health and Finance (decisions) } \\
\text { - National Health Insurance Fund Administration } \\
\text { (recommendations) })^{88,89}\end{array}$ & $\begin{array}{l}\text { Referred by: } \\
\text { - Manufacturers seeking reimbursement } \\
\text { for newly approved pharmaceuticals } \\
\text { - National Health Insurance Fund Administration }{ }^{88}\end{array}$ \\
\hline
\end{tabular}




\begin{tabular}{|c|c|c|}
\hline \multirow[b]{2}{*}{ Technology selection } & \multicolumn{2}{|l|}{ Health technology assessment } \\
\hline & $\begin{array}{l}\text { Synthesis and analysis of } \\
\text { evidence (assessment report) }\end{array}$ & $\begin{array}{l}\text { Evaluation of evidence provided } \\
\text { (evaluation report) }\end{array}$ \\
\hline $\begin{array}{l}\text { - Typically considered in } \\
\text { order received }^{58}\end{array}$ & $\begin{array}{l}\text { - Manufacturer through submission requirements }{ }^{55} \\
\text { - Methods should comply with internationally } \\
\text { recognized systematic review and economic } \\
\text { guidelines }^{55}\end{array}$ & $\begin{array}{l}\text { - Technical staff within Association of Austrian } \\
\text { Social Security Institutions (Department of } \\
\text { Pharmaceutical Affairs - pharmacological } \\
\text { and medical-therapeutic assessment; Health } \\
\text { Economics Team - economic assessment) }\end{array}$ \\
\hline $\begin{array}{l}\text { - Typically considered in } \\
\text { order received }^{17}\end{array}$ & $\begin{array}{l}\text { - Manufacturer through submission requirements } \\
\text { - Methods should comply with internationally } \\
\text { recognized systematic review guidelines }\end{array}$ & $\begin{array}{l}\text { - Technical staff within CRM supported } \\
\text { by external experts9 }\end{array}$ \\
\hline $\begin{array}{l}\text { - Typically considered in } \\
\text { order received }^{65}\end{array}$ & $\begin{array}{l}\text { - Manufacturer through submission } \\
\text { requirements }^{66}\end{array}$ & $\begin{array}{l}\text { - Technical staff within State Institute } \\
\text { for Drug Control }{ }^{65}\end{array}$ \\
\hline $\begin{array}{l}\text { - Typically considered in } \\
\text { order received }{ }^{84}\end{array}$ & $\begin{array}{l}\text { - Manufacturer through submission requirements } \\
\text { - Methods must comply with "Danish guidelines } \\
\text { for the socioeconomic analysis of medicines" }{ }^{68}\end{array}$ & $\begin{array}{l}\text { - Technical staff within Danish Medicines } \\
\text { Agency supported by external experts, } \\
\text { if necessary }{ }^{68}\end{array}$ \\
\hline - Not specified & $\begin{array}{l}\text { - Manufacturer through } \\
\text { submission requirements }{ }^{72}\end{array}$ & $\begin{array}{l}\text { - Technical staff within Estonian Health } \\
\text { Insurance Fund and State Agency of Medicines }\end{array}$ \\
\hline $\begin{array}{l}\text { - Typically considered in } \\
\text { order received }^{73}\end{array}$ & $\begin{array}{l}\text { - Manufacturer through } \\
\text { submission requirements } \\
\text { - Methods must comply with guidelines of } \\
\text { the Ministry of Social Affairs and Health }{ }^{122}\end{array}$ & $\begin{array}{l}\text { - Technical staff within Pharmaceuticals } \\
\text { Pricing Board supported by external experts }\end{array}$ \\
\hline $\begin{array}{l}\text { Single technology appraisals } \\
\text { - Typically considered in order } \\
\text { received }^{16}\end{array}$ & $\begin{array}{l}\text { Single technology appraisals } \\
\text { - Manufacturer through submission requirements }{ }^{20} \\
\text { Multiple technology appraisals }\end{array}$ & $\begin{array}{l}\text { Single technology appraisals } \\
\text { - Technical staff within Health and Social } \\
\text { Security supported by external experts }{ }^{20}\end{array}$ \\
\hline $\begin{array}{l}\text { Multiple technology appraisals } \\
\text { - Selection criteria not specified }\end{array}$ & $\begin{array}{l}\text { - Technical staff within Health and Social } \\
\text { Security supported by external experts }{ }^{20} \\
\text { - Methods should comply with } \\
\text { internationally recognized systematic } \\
\text { review and economic guidelines }{ }^{20}\end{array}$ & $\begin{array}{l}\text { Multiple technology appraisals } \\
\text { - Technical staff within Health and Social } \\
\text { Security or independent academic group }\end{array}$ \\
\hline $\begin{array}{l}\text { - Determined by Federal } \\
\text { Joint Committee }\end{array}$ & $\begin{array}{l}\text { - Technical staff within Institute for } \\
\text { Quality and Efficiency in Health }\end{array}$ & $\begin{array}{l}\text { - Technical staff within Institute for } \\
\text { Quality and Efficiency in Health }\end{array}$ \\
\hline $\begin{array}{l}\text { - Selection criteria: } \\
\text { I. Clinical relevance } \\
\text { 2. Cost implications } \\
\text { 3. "Risks"6 }\end{array}$ & $\begin{array}{l}\text { Care supported by external experts }{ }^{12,124} \\
\text { - Methods must comply with Institute for } \\
\text { Quality and Efficiency in Health Care } \\
\text { systematic review and economic guidelines }\end{array}$ & Care supported by external experts ${ }^{123,124}$ \\
\hline - Not specified & $\begin{array}{l}\text { - Manufacturer through } \\
\text { submission requirements }{ }^{85}\end{array}$ & $\begin{array}{l}\text { - Technical staff within Transparency } \\
\text { Committee in the Reimbursement } \\
\text { and Medicinal Products }{ }^{85}\end{array}$ \\
\hline - Not specified & $\begin{array}{l}\text { - Technical staff within National } \\
\text { Technology Assessment Office of } \\
\text { the National Institute for Strategic } \\
\text { Health Research }\end{array}$ & $\begin{array}{l}\text { - Technical staff within National Technology } \\
\text { Assessment Office of the National Institute } \\
\text { for Strategic Health Research }\end{array}$ \\
\hline
\end{tabular}

(Continued) 
Table 2 (Continued)

\begin{tabular}{|c|c|c|}
\hline \multirow[t]{2}{*}{ Country } & \multirow{2}{*}{$\begin{array}{l}\text { Centralized reimbursement reviewl } \\
\text { decision-making body (role) }\end{array}$} & \multirow[t]{2}{*}{ Technologies to be considered for review } \\
\hline & & \\
\hline Ireland & - Health Service Executive (decisions) ${ }^{91,92}$ & $\begin{array}{l}\text { Referred by: } \\
\text { - Manufacturers seeking reimbursement } \\
\text { for newly approved pharmaceuticals" } \\
\text { Referred by: } \\
\text { - Department of Health and Children of the Health Services } \\
\text { Executive for new and existing devices and diagnostic tests that } \\
\text { might "incur a high cost or have a significant budget impact"91 }\end{array}$ \\
\hline Italy & $\begin{array}{l}\text { - Italian Medicines Agency Technical } \\
\text { Scientific Committee (decisions) } \\
\text { - Italian Medicines Agency Pricing and } \\
\text { Reimbursement Committee (recommendations) }\end{array}$ & $\begin{array}{l}\text { Referred by: } \\
\text { - Manufacturers seeking reimbursement } \\
\text { for newly approved pharmaceuticals }{ }^{27}\end{array}$ \\
\hline Norway & $\begin{array}{l}\text { - Norwegian Medicines Agency (decisions) } \\
\text { - Department of Pharmacoeconomics } \\
\text { (recommendations) }^{98}\end{array}$ & $\begin{array}{l}\text { Referred by: } \\
\text { - Manufacturers seeking reimbursement for } \\
\text { newly approved pharmaceuticals }{ }^{34}\end{array}$ \\
\hline Poland & - Ministry of Health (decisions) ${ }^{99}$ & $\begin{array}{l}\text { Referred by: } \\
\text { - Manufacturers seeking reimbursement } \\
\text { for newly approved pharmaceuticals }{ }^{99}\end{array}$ \\
\hline Portugal & $\begin{array}{l}\text { - Ministry of Health (decisions) } \\
\text { - INFARMED (recommendations) }\end{array}$ & $\begin{array}{l}\text { Referred by: } \\
\text { - Manufacturers seeking reimbursement } \\
\text { for newly approved pharmaceuticals }{ }^{36}\end{array}$ \\
\hline Scotland & $\begin{array}{l}\text { - National Health Service Scotland (decisions) }{ }^{30} \\
\text { - Scottish Medicines Consortium } \\
\text { (recommendations) }\end{array}$ & $\begin{array}{l}\text { Referred by: } \\
\text { - Manufacturers seeking reimbursement for } \\
\text { newly approved pharmaceuticals }{ }^{104} \\
\text { - Automatic within } 12 \text { weeks of market launch }{ }^{104}\end{array}$ \\
\hline Slovakia & $\begin{array}{l}\text { - Ministry of Health (decisions) } \\
\text { - Reimbursement Committee for } \\
\text { Medicinal Products (recommendations) }{ }^{105,107,129,106}\end{array}$ & $\begin{array}{l}\text { Referred by: } \\
\text { - Manufacturers seeking reimbursement for } \\
\text { newly approved pharmaceuticals }{ }^{104}\end{array}$ \\
\hline Spain & $\begin{array}{l}\text { - Ministry of Health Directorate General } \\
\text { of Pharmacy and Health Products } \\
\text { - Inter-Ministerial Pricing Commission } \\
\text { (decisions) }{ }^{21,108}\end{array}$ & $\begin{array}{l}\text { Referred by: } \\
\text { - Ministry of Health (newly approved pharmaceuticals) }\end{array}$ \\
\hline Sweden & $\begin{array}{l}\text { - Dental and Pharmaceutical Benefits } \\
\text { Board (decisions) }{ }^{15,109,110}\end{array}$ & $\begin{array}{l}\text { Referred by: } \\
\text { - Manufacturers seeking reimbursement } \\
\text { for newly approved pharmaceuticals }{ }^{104} \\
\text { - Dental and Pharmaceutical Benefits Board } \\
\text { (for pharmaceuticals approved prior to 2002) }\end{array}$ \\
\hline Switzerland & $\begin{array}{l}\text { - Swiss Federal Office of } \\
\text { Public Health (decisions) } \\
\text { - Federal Drug Commission } \\
\text { (recommendations) }{ }^{114,115}\end{array}$ & $\begin{array}{l}\text { Referred by: } \\
\text { - Manufacturers seeking reimbursement } \\
\text { for newly approved pharmaceuticals } \\
\text { - Patients and carers } \\
\text { - Hospitals and hospital groups } \\
\text { - Health care professional associations } \\
\text { - Federal Office of Public Health }\end{array}$ \\
\hline The Netherlands & $\begin{array}{l}\text { - Ministry of Health, Welfare } \\
\text { and Sport (decisions) } \\
\text { - Medicinal Products Reimbursement } \\
\text { Committee of the Dutch Healthcare } \\
\text { Insurance Board (recommendations) }\end{array}$ & $\begin{array}{l}\text { Referred by: } \\
\text { - Manufacturers seeking reimbursement for } \\
\text { newly approved pharmaceuticals }{ }^{3 !} \\
\text { - University hospital federations, health care professional } \\
\text { associations, and Dutch Healthcare Insurance Board for } \\
\text { high-cost inpatient pharmaceuticals }\end{array}$ \\
\hline
\end{tabular}




\begin{tabular}{|c|c|c|}
\hline & Health technology assessment & \\
\hline Technology selection & $\begin{array}{l}\text { Synthesis and analysis of } \\
\text { evidence (assessment report) }\end{array}$ & $\begin{array}{l}\text { Evaluation of evidence provided } \\
\text { (evaluation report) }\end{array}$ \\
\hline - Not specified & $\begin{array}{l}\text { - Manufacturer through submission } \\
\text { requirements }{ }^{93,125} \\
\text { - Methods must comply with Irish } \\
\text { Health Technology Assessment Guidelines }\end{array}$ & $\begin{array}{l}\text { - Technical staff within National Centre for } \\
\text { Pharmacoeconomics, supported by external } \\
\text { clinical experts }^{93}\end{array}$ \\
\hline
\end{tabular}

- Typically considered in order received ${ }^{27}$

- Not specified

- Not specified

- Not specified

- Exclusion criteria:

Already appraised by National Institute of Health and Clinical Excellence through its multiple technologies appraisal process ${ }^{104}$

- Not specified

- Not specified

- For new pharmaceuticals: typically considered in order received

- For older pharmaceuticals: Overall sales volume ${ }^{134,135}$

- Not specified
- Manufacturer through submission requirements ${ }^{126}$

- Methods must comply with Italian submission guidelines ${ }^{27}$

- Manufacturer through submission requirements ${ }^{34}$

- Methods should comply with internationally recognized systematic review guidelines ${ }^{34}$

- Manufacturer through submission requirements 99

- Manufacturer through submission requirements ${ }^{36}$

- Manufacturer through submission requirements ${ }^{128}$

- Methods must comply with Scottish Medicines Consortium systematic review and economic guidelines ${ }^{34}$

- Manufacturer through submission requirements ${ }^{|3|}$

- Manufacturer through invitation to submit information to Inter-Ministerial Pricing Commission ${ }^{21}$

- Technical staff within Ministry of Health ${ }^{132}$

- For new pharmaceuticals: Manufacturer through submission requirements ${ }^{136}$

- For older pharmaceuticals: Technical staff within Dental and Pharmaceutical Benefits Board supported by external experts ${ }^{136}$

- Methods must comply with Dental and Pharmaceutical Benefits Board systematic review and economic guidelines ${ }^{10}$

- Manufacturer through submission requirements ${ }^{1 / 3}$
- Members of Technical Scientific Committee ${ }^{126}$

- Technical staff within Norwegian Medicines Agency and Department of Pharmacoeconomics ${ }^{98}$

- Technical staff within Ministry of Health ${ }^{99}$

- Agency for Health Technology Assessment ${ }^{127}$

- Technical staff within INFARMED supported by external experts ${ }^{36}$

- Technical staff within Scottish Medicines Consortium supported by external experts ${ }^{128}$

- Working group for pharmacoeconomics and outcomes research ${ }^{131}$

- Inter-Ministerial Pricing Commission ${ }^{21}$

- For new pharmaceuticals: Technical staff within Dental and Pharmaceutical Benefits Board ${ }^{136}$

- For older pharmaceuticals: Technical staff within Dental and Pharmaceutical Benefits Board supported by external experts ${ }^{136}$

- Federal Drug Commission ${ }^{114}$

- Not specified

- Manufacturer through submission requirements ${ }^{31}$

- Technical staff within Dutch

Healthcare Insurance Board ${ }^{117}$

- Methods must comply with internationally recognize systematic review guidelines and Dutch Healthcare Insurance Board economic guidelines ${ }^{117}$
- Technical staff within Dutch Healthcare Insurance Board ${ }^{117}$ 
Table 2 (Continued)

\begin{tabular}{|c|c|c|}
\hline \multirow[t]{2}{*}{ Country } & \multirow{2}{*}{$\begin{array}{l}\text { Centralized reimbursement review/ } \\
\text { decision-making body (role) }\end{array}$} & \multirow{2}{*}{$\frac{\text { Technologies to be considered for review }}{\text { Technology identification }}$} \\
\hline & & \\
\hline United Kingdom & $\begin{array}{l}\text { - National Institute for Health and } \\
\text { Clinical Excellence (decisions) } \\
\text { - Technology Appraisals } \\
\text { Committee (recommendations) }\end{array}$ & $\begin{array}{l}\text { Referred by: } \\
\text { - Manufacturers seeking reimbursement } \\
\text { for newly approved pharmaceuticals } \\
\text { - Patients and carers } \\
\text { - Health care providers } \\
\text { - Health care professional associations } \\
\text { - General Public } \\
\text { - National Horizon Scanning Centre }\end{array}$ \\
\hline Wales & $\begin{array}{l}\text { - Ministry for Health and Social } \\
\text { Services (decisions) } \\
\text { - All Wales Medicines Strategy } \\
\text { Group (recommendations) }\end{array}$ & $\begin{array}{l}\text { Referred by: } \\
\text { - Manufacturers seeking reimbursement for } \\
\text { newly approved pharmaceuticals }{ }^{28} \\
\text { - Welsh Medicines Partnership horizon scanning process } \\
\text { for identifying pharmaceuticals expected to receive market } \\
\text { approval within } 18 \text { months }{ }^{28}\end{array}$ \\
\hline
\end{tabular}

requirements for assessment reports (Tables 3 and 4). These guidelines state topics to be addressed and the types of information accepted for addressing them. In most cases (16/23), specified clinically-related topics are similar and include: burden of illness and/or characteristics of the target patient population; therapeutic claim of the candidate technology; safety; efficacy; and effectiveness (preferably comparative effectiveness) across relevant patient subgroups (Table 3). Additionally, several require information on current management or the place of the candidate technology within existing treatment pathways (eg, France and the UK), and its proposed frequency and duration of use (eg, Austria). Across systems and where reported, there is a shared preference for information on health outcomes that represent final clinical endpoints related to mortality, morbidity, and quality of life. Less frequently, information on adverse events/ complications is also required. This may be explained by the fact that a prerequisite for reimbursement review is typically regulatory approval. Therefore, systems may view reconsideration of adverse events, which relate to the safety of a technology, unnecessary. In systems proposing or stipulating the use of quality-adjusted life-years (7/23), change in health-related quality of life is to be measured in patients and then valued in the public or general population (eg, the UK). Surrogate outcomes are discouraged or not accepted unless well validated (eg, Germany). Lastly, some systems elicit the views of patients and or carers in identifying topic specific outcomes and their relative importance (eg, Germany).

In general, centralized reimbursement systems state a preference for head-to-head randomized controlled trials comparing the candidate technology with standard care, no active treatment/best supportive care, or placebo (if no alternatives exist, Table 3). However, increased interest in evidence of "comparative effectiveness" over "comparative efficacy" among most reimbursement systems has led to requests for inclusion of head-to-head randomized controlled trials conducted in "naturalistic settings" (ie, pragmatic trials, in the UK) and other direct comparative studies (observational and experimental in design), the collective findings of which may offer a more accurate prediction of the behavior of the technology in general clinical practice (eg, France, Germany, and Sweden). Also, there appears to be emerging recognition of the need for flexibility in evidence expectations under certain circumstances. Recently, Germany's Institute for Quality and Efficiency in Health Care, which conducts 


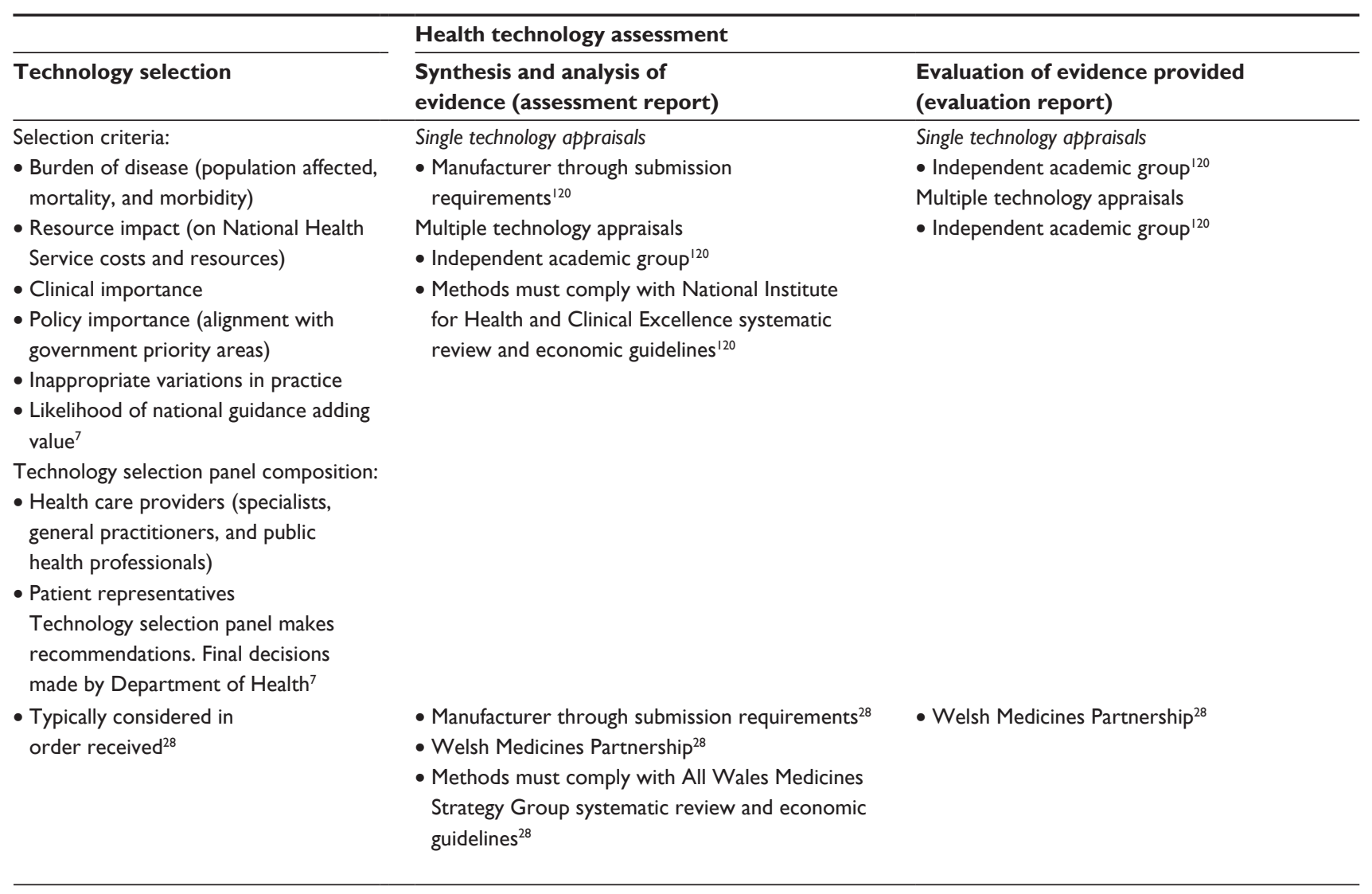

health technology assessments and makes reimbursement recommendations on selected health technologies to the Federal Joint Committee, issued methodological guidelines suggesting that when no active alternative treatment exists, well designed case series would be deemed adequate. ${ }^{8}$

While across systems, the preferred source of such clinical evidence is published, peer-reviewed studies, many encourage, and in several cases require if available, inclusion of unpublished or ongoing studies (eg, Austria, Belgium, Norway, Poland, Slovakia, Sweden, the Netherlands, and the UK), commercial in-confidence data (eg, Austria, France, Sweden, and the UK) and/or current national and international clinical practice guidelines (eg, France) in assessment reports. In recent years, some systems have incorporated submissions from patient and/or carer organizations into their processes (eg, Scotland, Sweden, and the UK). Such submissions are increasingly viewed as an important source of information regarding the relative value of outcome measures employed in clinical studies and the meaningfulness or significance of findings to patients and carers. Finally, while systems tend not to explicitly exclude sources of information, Belgium's Drug Reimbursement Committee states that abstracts are not accepted. ${ }^{9}$
Most centralized reimbursement systems (20/23) have made mandatory the inclusion of a formal economic evaluation/analysis for either some (ie, those for which alternative(s) exist(s), eg, Germany, or those offering "added therapeutic value," eg, Austria and Belgium, or all candidate technologies to inform deliberations around "value for money" and/or "efficiency." In the latter case, the type of evaluation is rarely stipulated, because options available depend, in part, on the magnitude of the incremental benefit of the technology over its comparators. However, a rationale must be presented, and methods adopted must comply with economic guidelines developed or endorsed by the centralized reimbursement system (Table 4). For technologies that appear to offer "added therapeutic value" (ie, are more effective), some systems indicate a preference for certain types of evaluations, such as cost-utility analysis by Ireland's Health Service Executive. ${ }^{10}$ Others state explicitly which types will not be accepted, such as cost-benefit analysis by Belgium's Drug Reimbursement Committee. ${ }^{11}$ In addition to a formal economic evaluation, the Institute for Quality and Efficiency in Health Care in Germany requires an efficiency frontier analysis, which assesses the relative value of different technologies within a given therapeutic area. ${ }^{12}$ Regarding the perspective to be taken for 
Table 3 Comparison of clinical evidence requirements

\begin{tabular}{|c|c|c|}
\hline \multirow[t]{2}{*}{ Country } & \multirow{2}{*}{$\begin{array}{l}\text { Centralized reimbursement } \\
\text { review/decision-making body (role) }\end{array}$} & \multirow{2}{*}{$\begin{array}{l}\text { Clinical evidence requirements } \\
\text { Topic }\end{array}$} \\
\hline & & \\
\hline Austria & $\begin{array}{l}\text { - Association of Austrian Social Security Institutions } \\
\text { (decisions) }^{55} \\
\text { - Pharmaceutical Evaluation Board (recommendations) }{ }^{56}\end{array}$ & $\begin{array}{l}\text { - Target patient population and indications } \\
\text { (therapeutic claim) } \\
\text { - Pharmacology } \\
\text { - Safety } \\
\text { - Efficacy } \\
\text { - Effectiveness (across population subgroups) } \\
\text { - Frequency and duration of treatment }{ }^{55}\end{array}$ \\
\hline Belgium & $\begin{array}{l}\text { - Minister of Social Affairs (decisions) } \\
\text { - Commission on reimbursement of medicines/Drug } \\
\text { Reimbursement Committee (recommendations) }\end{array}$ & $\begin{array}{l}\text { - Target patient population and indications (therapeutic claim) } \\
\text { - Safety } \\
\text { - Efficacy } \\
\text { - Effectiveness (across population subgroups)" }\end{array}$ \\
\hline Czech Republic & - State Institute for Drug Control (decisions) ${ }^{65}$ & $\begin{array}{l}\text { - Safety } \\
\text { - Efficacy } \\
\text { - Effectiveness } \\
\text {-6 }\end{array}$ \\
\hline Denmark & $\begin{array}{l}\text { - Danish Medicines Agency (decisions) } \\
\text { - Reimbursement } 121 \\
\text { Reimmittee (recommendations) }{ }^{68,121}\end{array}$ & $\begin{array}{l}\text { - Target patient population and indications (therapeutic claim) } \\
\text { - Safety } \\
\text { - Efficacy } \\
\text { - Effectiveness (across population subgroups) }\end{array}$ \\
\hline Estonia & $\begin{array}{l}\text { - Ministry of Social Affairs (decisions) }{ }^{72} \\
\text { - Pharmaceuticals Committee (recommendations) }{ }^{67}\end{array}$ & $\begin{array}{l}\text { - Safety } \\
\text { - Efficacy } \\
\text { - Effectiveness }{ }^{139}\end{array}$ \\
\hline Finland & $\begin{array}{l}\text { - Pharmaceuticals Pricing Board (decisions) })^{73,74,76} \\
\text { - Pharmaceuticals Pricing Board Expert Group } \\
\text { (recommendations) })^{75}\end{array}$ & $\begin{array}{l}\text { - Target patient population and indications (therapeutic claim) } \\
\text { - Severity and burden of illness } \\
\text { - Effectiveness (across population subgroups) })^{76}\end{array}$ \\
\hline France & $\begin{array}{l}\text { - Ministry for Health and Social Security } \\
(\text { decisions })^{20,78} \\
\text { - French National Authority for Health } \\
\text { (recommendations })^{20,78}\end{array}$ & $\begin{array}{l}\text { - Target patient population and indications (therapeutic claim) } \\
\text { - Current management } \\
\text { - Place of technology in care pathway } \\
\text { - Safety } \\
\text { - Efficacy } \\
\text { - Effectiveness (across population subgroups) })^{16}\end{array}$ \\
\hline Germany & $\begin{array}{l}\text { - Federal Joint Committee (decisions) })^{19} \\
\text { - Institute for Quality and Efficiency in Health Care } \\
\text { (recommendations) }^{19,141}\end{array}$ & $\begin{array}{l}\text { - Target patient population and indications (therapeutic claim) } \\
\text { - Severity and burden of illness } \\
\text { - Safety } \\
\text { - Efficacy } \\
\text { - Effectiveness (across population subgroups) }\end{array}$ \\
\hline Greece & $\begin{array}{l}\text { - Transparency Committee in the Reimbursement } \\
\text { and Medicinal Products (makes decisions) }\end{array}$ & $\begin{array}{l}\text { - Safety } \\
\text { - Efficacy } \\
\text { - Effectiveness }{ }^{145}\end{array}$ \\
\hline
\end{tabular}




\begin{tabular}{lll}
\hline Preferred clinical outcomes & Type & Source \\
\hline - Not specified & Preference for: & $\bullet$ Published, peer-reviewed studies \\
& • Double-blind randomized controlled trials & $\bullet$ Unpublished reports and studies may be \\
& - Systematic reviews and meta-analyses of randomized & accepted in exceptional circumstances \\
& controlled trials complying with internationally \\
& recognized guidelines ${ }^{55}$ & $\bullet$ Commercial, in-confidence data
\end{tabular}

- Morbidity

- Adverse events/complications

- Quality of life

- Overall survival/mortality (life-years gained)

- Quality-adjusted life years

(QALYs) - measured in patients but valued by public/society

- Other relevant disease-specific outcomes $^{4}$

- Final endpoints ${ }^{\prime \prime}$

- Not specified

- Not specified

- Adverse events/complications

- Side effects

- Overall survival/mortality ${ }^{139,140}$

- Not specified

- Morbidity

- Overall survival/mortality

- Quality of life ${ }^{16}$

- Morbidity

- Overall survival/mortality

- Quality of life

- Adverse events/complications

- Side effects

- Duration of illness

- Health status ${ }^{8,83,142-144}$

- Topic specific outcomes identified in consultation with patient organizations $^{18}$

- Validated surrogate outcomes ${ }^{83}$

- Not specified
Preference for:

- Randomized controlled trials

- Observational head-to-head comparative studies ${ }^{11,17}$

- Effectiveness studies (over efficacy studies) ${ }^{17}$

- Minimum of one positive superiority trial on primary endpoints against active control or placebo (if no alternative treatments exist) ${ }^{17}$

- All clinical trials ${ }^{138}$

Preference for:

- Randomized controlled trials comparing pharmaceutical to standard care ${ }^{38}$

Preference for:

- Randomized controlled trials ${ }^{84}$

Preference for:

- Randomized controlled trials comparing pharmaceutical to standard care ${ }^{76}$

Evidence from other available direct comparative experimental and observational studies, as well as meta-analyses, should be included ${ }^{76}$

Preference for:

- Head-to-head, double-blind randomized controlled trials

- Other direct comparative studies

- Post-market studies

- Systematic reviews and meta-analyses of randomized controlled trials complying with internationally recognized guidelines ${ }^{16}$

Preference for:

- Randomized controlled trials comparing pharmaceutical to placebo, standard care, or no active treatment ${ }^{8}$

Evidence from other available direct comparative experimental and observational studies, as well as systematic reviews and meta-analyses complying with internationally recognized guidelines,

should also be included ${ }^{8}$

- If no treatment alternative exists, well-documented case series acceptable ${ }^{8}$

- Not specified
- Published, peer-reviewed studies - Unpublished reports and studies ${ }^{17}$

- Abstracts not accepted ${ }^{9}$

- Not specified

- Not specified

- Published, peer-reviewed studies ${ }^{84}$

- Published, peer-reviewed studies ${ }^{76}$

- Published, peer-reviewed studies

- Current national and international clinical practice guidelines

- Expert opinion

- Surveys of practice

- Commercial, in-confidence data ${ }^{16}$

- Published, peer-reviewed studies

- Commercial, in-confidence data not accepted unless it can be published ${ }^{18}$

(Continued) 
Table 3 (Continued)

\begin{tabular}{|c|c|c|}
\hline \multirow[t]{2}{*}{ Country } & \multirow{2}{*}{$\begin{array}{l}\text { Centralized reimbursement } \\
\text { review/decision-making body (role) }\end{array}$} & \multirow{2}{*}{$\begin{array}{l}\text { Clinical evidence requirements } \\
\text { Topic }\end{array}$} \\
\hline & & \\
\hline Hungary & $\begin{array}{l}\text { - Ministers of Health and Finance (decisions) } \\
\text { - National Health Insurance Fund Administration } \\
\text { (recommendations) }^{88}\end{array}$ & $\begin{array}{l}\text { - Severity and burden of illness } \\
\text { - Current management } \\
\text { - Safety } \\
\text { - Efficacy } \\
\text { - Effectiveness (across population subgroups) }{ }^{90}\end{array}$ \\
\hline Ireland & - Health Service Executive (decisions) ${ }^{91,92}$ & $\begin{array}{l}\text { - Safety } \\
\text { - Efficacy } \\
\text { - Effectiveness (across population subgroups) }\end{array}$ \\
\hline Italy & $\begin{array}{l}\text { - Italian Medicines Agency Technical Scientific } \\
\text { Committee (decisions) }{ }^{94} \\
\text { - Italian Medicines Agency Pricing and Reimbursement } \\
\text { Committee (recommendations) }{ }^{95}\end{array}$ & $\begin{array}{l}\text { - Target patient population and indications (therapeutic claim) } \\
\text { - Severity and burden of illness } \\
\text { - Current management } \\
\text { - Safety } \\
\text { - Efficacy } \\
\text { - Effectiveness (across population subgroups) }{ }^{148}\end{array}$ \\
\hline Norway & $\begin{array}{l}\text { - Norwegian Medicines Agency (decisions) } \\
\text { - Department of Pharmacoeconomics (recommendations) }{ }^{98}\end{array}$ & $\begin{array}{l}\text { - Target patient population and indications (therapeutic claim) } \\
\text { - Severity and burden of illness } \\
\text { - Current management } \\
\text { - Place of technology in care pathway } \\
\text { - Safety } \\
\text { - Efficacy } \\
\text { - Effectiveness (across population subgroups) })^{34,149}\end{array}$ \\
\hline Poland & - Ministry of Health (decisions) $)^{99,100}$ & $\begin{array}{l}\text { - Severity and burden of illness } \\
\text { - Current management } \\
\text { - Safety } \\
\text { - Efficacy } \\
\text { - Effectiveness (across population subgroups) }\end{array}$ \\
\hline Portugal & $\begin{array}{l}\text { - Ministry of Health (decisions) } \\
\text { - INFARMED (recommendations) }\end{array}$ & $\begin{array}{l}\text { - Safety } \\
\text { - Efficacy } \\
\text { - Effectiveness (across population subgroups) }\end{array}$ \\
\hline Scotland & $\begin{array}{l}\text { - National Health Service Scotland (decisions) } \\
\text { - Scottish Medicines Consortium (recommendations) }\end{array}$ & $\begin{array}{l}\text { - Target patient population and indications (therapeutic claim) } \\
\text { - Severity and burden of illness } \\
\text { - Current management } \\
\text { - Place of technology in care pathway } \\
\text { - "Comparative" safety } \\
\text { - Efficacy } \\
\text { - Effectiveness (across population subgroups) }\end{array}$ \\
\hline Slovakia & $\begin{array}{l}\text { - Ministry of Health (decisions) } \\
\text { - Reimbursement Committee for Medicinal Products } \\
\text { (recommendations) }^{105,107,130}\end{array}$ & $\begin{array}{l}\text { - Target patient population and indications (therapeutic claim) } \\
\text { - Severity and burden of illness } \\
\text { - Current management } \\
\text { - Patient acceptance } \\
\text { - Safety } \\
\text { - Efficacy } \\
\text { - Effectiveness } \\
\text { - Frequency and duration of treatment }{ }^{106}\end{array}$ \\
\hline Spain & $\begin{array}{l}\text { - Ministry of Health Directorate General of } \\
\text { Pharmacy and Health Products; Inter-Ministerial } \\
\text { Pricing Commission (decisions) }{ }^{21,108}\end{array}$ & $\begin{array}{l}\text { - Target patient population and indications (therapeutic claim) } \\
\text { - Severity and burden of illness } \\
\text { - Current management } \\
\text { - Safety } \\
\text { - Efficacy } \\
\text { - Effectiveness }{ }^{132}\end{array}$ \\
\hline
\end{tabular}




\begin{tabular}{lll}
\hline Preferred clinical outcomes & Type & Source \\
\hline - Not specified & Preference for: & $\bullet$ Published, peer-reviewed studies ${ }^{90}$ \\
& $\bullet$ Randomized controlled trials ${ }^{84}$ &
\end{tabular}

- Morbidity

- Overall survival/mortality

- Quality of life

- QALYs - measured in patients but valued by public/society ${ }^{146}$

- All other health benefits accrued by individuals ${ }^{147}$

- Morbidity

- Overall survival/mortality

- Quality of life 149

- Morbidity

- Overall survival/mortality

- Quality of life ${ }^{144}$

- Morbidity

- Overall survival/mortality

- Quality of life ${ }^{|5|}$

- Morbidity

- Overall survival/mortality

- Quality of life ${ }^{101}$

- Morbidity

- Overall survival/mortality

- Quality of life

- QALYs (strongly preferred) ${ }^{50}$

- Morbidity

- Overall survival/mortality

- Adverse events/complications

- Quality of life $e^{106}$
Preference for:

- Randomized controlled trials ${ }^{147}$

Evidence from other available direct comparative

experimental and observational studies, as well

as systematic reviews and meta-analyses complying

with Irish Health Technology Assessment

Guidelines, should also be included ${ }^{146}$

Preference for:

- Randomized controlled trials comparing

pharmaceutical to standard care ${ }^{97}$

- Evidence from other available direct experimental and observational studies comparing pharmaceutical with standard care ${ }^{148}$

Preference for:

- Head-to-head, double-blind randomized controlled trials

- Other direct comparative studies

- Systematic reviews and meta-analyses complying

with internationally recognized guidelines ${ }^{149,150}$

Preference for:

- Randomized controlled trials ${ }^{151}$

Preference for:

- Effectiveness studies of target population (over efficacy studies) ${ }^{101}$

- Comparative clinical trials

- Other study designs accepted, but rationale must be provided ${ }^{101}$

- Randomized controlled trials required

- Comparative observational studies accepted ${ }^{50}$

- If no head-to head studies available, indirect comparison required ${ }^{50}$

Preference for:

- Comparative studies ${ }^{84}$
- Not specified

- Not specified

- Published, peer-reviewed studies

- Unpublished reports and studies ${ }^{149,150}$
- Published, peer-reviewed studies - Unpublished reports and studies ${ }^{|5|}$
- Not specified

- Published, peer-reviewed studies - Unpublished reports and studies

- Expert opinion

- Submissions from patient and carer organizations $^{128}$

- Published, peer-reviewed studies - Unpublished reports and studies with negative findings ${ }^{152}$
Preference for:

- Randomized controlled trials

Evidence from other available direct comparative experimental and observational studies should also be included ${ }^{132}$
- Not specified
- Overall survival/mortality

- Quality of life

- QALYs ${ }^{132}$ 
Table 3 (Continued)

\begin{tabular}{|c|c|c|}
\hline \multirow[t]{2}{*}{ Country } & \multirow{2}{*}{$\begin{array}{l}\text { Centralized reimbursement } \\
\text { review/decision-making body (role) }\end{array}$} & \multirow{2}{*}{$\begin{array}{l}\text { Clinical evidence requirements } \\
\text { Topic }\end{array}$} \\
\hline & & \\
\hline \multirow[t]{6}{*}{ Sweden } & - Dental and Pharmaceutical Benefits Board (decisions) ${ }^{15,109}$ & - Target patient population and indications (therapeutic claim) \\
\hline & & - Severity and burden of illness \\
\hline & & - Current management \\
\hline & & - Safety \\
\hline & & - Efficacy \\
\hline & & - Effectiveness ${ }^{153}$ \\
\hline \multirow[t]{3}{*}{ Switzerland } & - Swiss Federal Office of Public Health (decisions) & - Safety \\
\hline & - Federal Drug Commission (recommendations) $)^{1 / 3-1 / 5}$ & - Efficacy \\
\hline & & - Effectiveness ${ }^{113}$ \\
\hline \multirow[t]{5}{*}{ The Netherlands } & - Ministry of Health, Welfare and Sport (decisions) & - Target patient population and indications (therapeutic claim) \\
\hline & - Medicinal Products Reimbursement Committee of & - Severity and burden of illness \\
\hline & the Dutch Healthcare Insurance Board & - Safety \\
\hline & (recommendations) $)^{116}$ & - Efficacy \\
\hline & & - Effectiveness ${ }^{154}$ \\
\hline \multirow[t]{7}{*}{ United Kingdom } & - National Institute for Health and Clinical & - Target patient population and indications (therapeutic claim) \\
\hline & Excellence (decisions) & - Severity and burden of illness \\
\hline & - Technology Appraisals Committee (recommendations) ${ }^{7}$ & - Current management \\
\hline & & - Place of technology in care pathway \\
\hline & & - "Comparative" safety \\
\hline & & - Efficacy \\
\hline & & - Effectiveness (across population subgroups) ${ }^{29}$ \\
\hline \multirow[t]{7}{*}{ Wales } & - Ministry for Health and Social Services (decisions) & - Target patient population and indications (therapeutic claim) \\
\hline & - All Wales Medicines Strategy Group (recommendations) ${ }^{120}$ & - Severity and burden of illness \\
\hline & & - Current management \\
\hline & & - Place of technology in care pathway \\
\hline & & - "Comparative" safety \\
\hline & & - Efficacy \\
\hline & & - Effectiveness (across population subgroups) ${ }^{28}$ \\
\hline
\end{tabular}

the economic evaluation, the proportion of systems adopting a "payer," "societal," or both "payer" and "societal" perspective is similar. Among systems considering a payer's perspective only, costs to be captured are often restricted to those directly related to care associated with the use of the candidate technology throughout the course of a disease or condition (ie, direct costs to the health care system). One exception is the National Institute of Health and Clinical Excellence, which specifies inclusion of direct and indirect costs to the National Health Service and Personal Social Services. ${ }^{13}$ In systems requiring a societal perspective, costs specified comprise direct costs to not only the health care system, but also services beyond health care and indirect (lost productivity) costs. However, they must be reported separately (eg, Finland, Portugal, and the Netherlands). In Sweden, The Dental and Pharmaceutical Benefits Board has taken a wider view on indirect costs, requesting that time lost by patients and carers be considered, along with lost productivity. ${ }^{14,15}$ Thus, its methods broadly resemble those of "holistic" economic analysis, a technique initially developed for economic evaluations of public programs, the costs and benefits of which are often complex. Nevertheless, considerable debate over the valuation of items such as "time lost" within academic and policy communities remains. This may be why other systems employing a societal perspective have assumed a narrower position on eligible indirect costs. With respect to the choice of comparator for the economic evaluation, almost all systems specify use of one of the following: "standard care," "the most commonly used alternative," or "alternative most likely to be replaced." France also requires separate analyses with two additional comparators, ie, the most recently reimbursed alternative and the least expensive alternative. ${ }^{16}$ In Belgium, if the candidate technology represents an "addon" treatment, the comparator must constitute current treatment without the candidate technology. ${ }^{17}$ Further, the use of "offlabel" treatments as the comparator is not permitted. ${ }^{11}$ All systems rely upon sensitivity analyses to assess the stability of estimates generated through the economic evaluation, but few stipulate the type. Among those that do, probabilistic sensitivity analysis is the most commonly prescribed (eg, Belgium, Germany, Scotland, Slovakia, the UK, and Wales). 


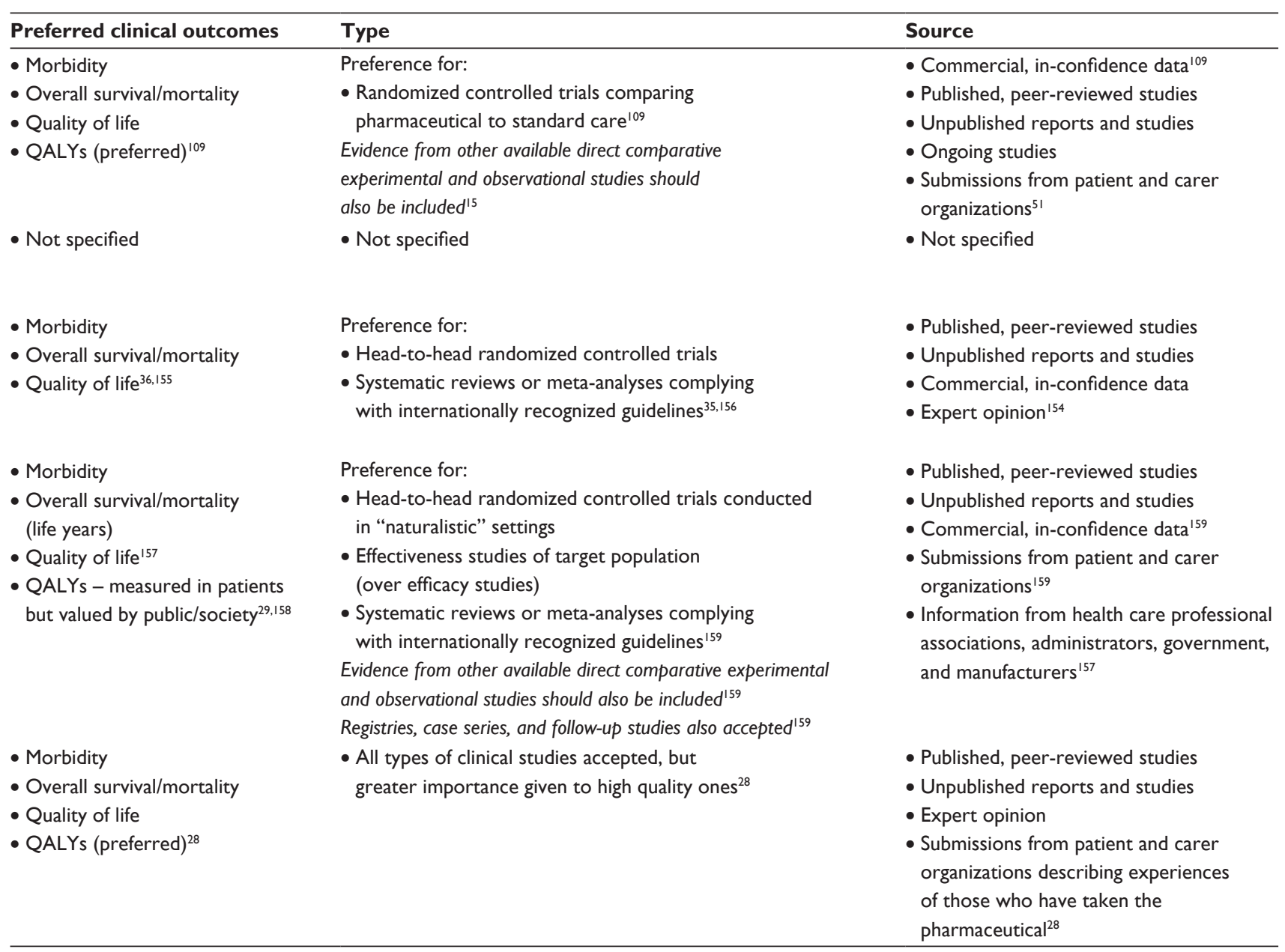

In recent years, affordability has become an increasingly important consideration for centralized reimbursement systems, with almost all of those included in this review (where information could be found) requiring a budget impact analysis (Table 4). However, some waive this analysis in certain circumstances, eg, when no alternative treatment exists (Belgium). ${ }^{17}$ Although information describing the specific costs to be included appears scarce, based on that available, they mirror those for the economic evaluation of the same technology. Specifically, if the economic evaluation is limited to direct costs, so must the budget impact analysis, eg, Hungary and Ireland.

\section{Reimbursement decisions: review committee composition, procedures, and key factors}

In most of the centralized reimbursement systems, the assessment and evaluation reports are sent to and scrutinized by a review committee (sometimes referred to as an appraisal committee). While the composition of this committee varies across systems, it is usually multidisciplinary, with members representing payers, administrators, health care providers, and academia (eg, health economists, Table 5). Approximately one-third have also appointed patient representatives to their respective committees (eg, Sweden, Switzerland, and the UK), although not always as voting members (Germany), ${ }^{18,19}$ and one-fifth include manufacturers (Belgium, Switzerland, the UK, and Wales). In most systems, the authority of the review committee is advisory (ie, makes recommendations). Aside from lists of factors/criteria considered (Table 6), publicly available procedural information on committee deliberations is often limited to conditions under which presentations/testimonials from external experts (including patients) are sought or accepted and whether an incremental cost-effectiveness ratio threshold is employed. Among the exceptions is France. There, review committees (the Commission d'Evaluation des Medicaments (CEM), followed by the Transparency Commission) adhere to a two stage process. First, the CEM assigns a "medical benefit" or "SMR" level/ 
Table 4 Comparison of economic evidence requirements

\begin{tabular}{|c|c|c|c|c|}
\hline \multirow[t]{2}{*}{ Country } & \multirow{2}{*}{$\begin{array}{l}\text { Centralized reimbursement } \\
\text { review/decision-making } \\
\text { body (role) }\end{array}$} & \multicolumn{3}{|l|}{ Economic analysis } \\
\hline & & Required & $\begin{array}{l}\text { Economic analysis } \\
\text { types accepted }\end{array}$ & $\begin{array}{l}\text { Perspectivel } \\
\text { costs included }\end{array}$ \\
\hline Austria & $\begin{array}{l}\text { - Association of Austrian } \\
\text { Social Security Institutions } \\
{\text { (decisions) })^{55}}^{\text {Pharmaceutical Evaluation }} \\
\text { Board (recommendations) })^{56}\end{array}$ & $\begin{array}{l}\text { Yes for: } \\
\text { - "innovative products providing } \\
\text { substantial therapeutic benefit } \\
\text { - "where no comparable medical } \\
\text { preparation exists"21 }\end{array}$ & $\begin{array}{l}\text { - Any type, but rationale } \\
\text { for selection must be } \\
\text { provided } \\
\text { - Should comply } \\
\text { with internationally } \\
\text { recognized } \\
\text { pharmacoeconomic } \\
\text { guidelines }{ }^{21}\end{array}$ & $\begin{array}{l}\text { - Payer }{ }^{21} \\
\text { - Costs not } \\
\text { specified }\end{array}$ \\
\hline Belgium & $\begin{array}{l}\text { - Minister of Social Affairs } \\
\text { (decisions) } \\
\text { - Commission on } \\
\text { reimbursement of medicines/ } \\
\text { drug reimbursement } \\
\text { committee } \\
\text { (recommendations) } \\
9,60\end{array}$ & $\begin{array}{l}\text { Yes for: } \\
\text { - Pharmaceuticals with added } \\
\text { therapeutic value relative to } \\
\text { existing alternatives (Class II) } \\
\text { Not required for orphan } \\
\text { pharmaceuticals }\end{array}$ & $\begin{array}{l}\text { - Cost effectiveness } \\
\text { - Cost utility } \\
\text { - Cost benefit not } \\
\text { accepted"1 } \\
\text { - Should comply } \\
\text { with Belgium } \\
\text { pharmacoeconomic } \\
\text { guidelines }^{17}\end{array}$ & $\begin{array}{l}\text { - Payer (includes } \\
\text { patient } \\
\text { copayments and } \\
\text { government) } \\
\text { - Direct costs } \\
\text { only }^{11,17}\end{array}$ \\
\hline Czech & - State Institute for Drug & $Y_{e s}^{66}$ & - Cost effectiveness ${ }^{138}$ & - Payer 66 \\
\hline Republic & Control (decisions) ${ }^{65}$ & & & - Direct costs ${ }^{138}$ \\
\hline Denmark & $\begin{array}{l}\text { - Danish Medicines Agency } \\
\text { (decisions) }^{68,69,121} \\
\text { - Reimbursement Committee } \\
\text { (recommendations) }^{68,121}\end{array}$ & $\begin{array}{l}\text { No, but often included } \\
\text { to justify high price }{ }^{68,71,160}\end{array}$ & $\begin{array}{l}\text { - Cost effectiveness } \\
\text { - Cost utility } \\
\text { If included, methods } \\
\text { should comply with } \\
\text { Danish Guidelines for } \\
\text { the Socio-economic } \\
\text { Analysis of Medicines }{ }^{68}\end{array}$ & $\begin{array}{l}\text { - Societal } \\
\text { (if included) } \\
\text { - Direct, indirect, } \\
\text { and intangible; } \\
\text { to be reported } \\
\text { separately }{ }^{71}\end{array}$ \\
\hline Estonia & $\begin{array}{l}\text { - Ministry of Social Affairs } \\
(\text { decisions })^{72} \\
\text { - Pharmaceuticals Committee } \\
\text { (recommendations) })^{72}\end{array}$ & Yes $^{84,139}$ & $\begin{array}{l}\text { - Cost effectiveness } \\
\text { - Cost utility } \\
\text { - Cost minimization } \\
\text { rationale for selection } \\
\text { must be provided }^{139}\end{array}$ & $\begin{array}{l}\text { - Payer }{ }^{139} \\
\text { - May present } \\
\text { separate analysis } \\
\text { from societal } \\
\text { perspective }{ }^{84} \\
\text { - Direct costs within } \\
\text { and outside of the } \\
\text { health care system } \\
\text { (should be reported }^{\text {separately) }}{ }^{139}\end{array}$ \\
\hline Finland & $\begin{array}{l}\text { Pharmaceuticals Pricing } \\
\text { Board (decisions) })^{73,74,76} \\
\text { Pharmaceuticals Pricing } \\
\text { Board Expert Group } \\
\text { (recommendations) }^{75}\end{array}$ & $\begin{array}{l}\text { Yes for: } \\
\text { Pharmaceuticals considered } \\
\text { for reimbursement in one of } \\
\text { the special refund categories } \text { s }^{74,76}\end{array}$ & $\begin{array}{l}\text { - Any type, but } \\
\text { rationale for selection } \\
\text { must be provided } \\
\text { - Methods must comply } \\
\text { with Ministry of Social } \\
\text { Affairs and Health } \\
\text { guidelines }^{76}\end{array}$ & $\begin{array}{l}\text { - Societal }{ }^{76} \\
\text { - Direct and } \\
\text { indirect costs - } \\
\text { presented } \\
\text { separately }\end{array}$ \\
\hline France & $\begin{array}{l}\text { - Ministry for Health and } \\
\text { Social Security (decisions) } \text { ) }^{20,78} \\
\text { - French National Authority for } \\
\text { Health (recommendations) }{ }^{78}\end{array}$ & $\begin{array}{l}\text { Yes for: } \\
\text { - Multiple technology appraisals } \\
\text { of pharmaceuticals }{ }^{20}\end{array}$ & $\begin{array}{l}\text { - Any type, but } \\
\text { rationale for selection } \\
\text { must be provided }^{22} \\
\text { - Methods must comply } \\
\text { with French economic } \\
\text { guidelines }^{20}\end{array}$ & $\begin{array}{l}\text { - Varies, but should } \\
\text { take the widest } \\
\text { possible perspective- } \\
\text { rationale for } \\
\text { selection must } \\
\text { be provided }{ }^{84} \\
\text { - Direct costs; may } \\
\text { include indirect } \\
\text { costs, but must be } \\
\text { presented separately }\end{array}$ \\
\hline
\end{tabular}




\begin{tabular}{|c|c|c|c|c|c|}
\hline \multirow[b]{2}{*}{ Comparator } & \multirow[b]{2}{*}{$\begin{array}{l}\text { Sensitivity } \\
\text { analysis }\end{array}$} & \multirow[b]{2}{*}{$\begin{array}{l}\text { Systematic review } \\
\text { of economic } \\
\text { analysis studies }\end{array}$} & \multicolumn{2}{|c|}{ Budget impact analysis } & \multirow{2}{*}{$\begin{array}{l}\text { Other economic } \\
\text { information }\end{array}$} \\
\hline & & & Required & $\begin{array}{l}\text { Costs } \\
\text { included }\end{array}$ & \\
\hline $\begin{array}{l}\text { - Most commonly used } \\
\text { alternative }\end{array}$ & $\begin{array}{l}\text { Yes - type } \\
\text { not specified }{ }^{21}\end{array}$ & Yes & $\begin{array}{l}\text { No information } \\
\text { found }\end{array}$ & N/A & $\begin{array}{l}\text { - } 3 \text { year market sales forecast } \\
\text { - Price in other European Union } \\
\text { countries } \\
\text { - Reimbursement status in other } \\
\text { European Union countries }{ }^{55}\end{array}$ \\
\hline $\begin{array}{l}\text { - Most commonly used } \\
\text { alternative OR } \\
\text { - Alternative most likely } \\
\text { to be replaced } \\
\text { - If add-on: current } \\
\text { treatment without add-on }{ }^{17} \\
\text { - Off-label treatments not } \\
\text { acceptable } \\
\text { Rationale must be provided }\end{array}$ & Probabilistic $^{17}$ & Yes $^{17}$ & Yes" & $\begin{array}{l}\text { - Direct costs } \\
\text { only } 11,17\end{array}$ & $\begin{array}{l}\text { - Price } \\
\text { - Reimbursement status in other } \\
\text { European Union countries }{ }^{11,17}\end{array}$ \\
\hline No information found & $\begin{array}{l}\text { Method not } \\
\text { specified }\end{array}$ & $\begin{array}{l}\text { No information } \\
\text { found }\end{array}$ & $Y_{e s}^{138}$ & $\begin{array}{l}\text { No information } \\
\text { found }\end{array}$ & No information found \\
\hline $\begin{array}{l}\text { - Most commonly used } \\
\text { alternative }{ }^{38}\end{array}$ & $\begin{array}{l}\text { Method not } \\
\text { specified, but } \\
\text { key parameters } \\
\text { associated with } \\
\text { uncertainty } \\
\text { should be } \\
\text { explored }^{38}\end{array}$ & $\begin{array}{l}\text { No information } \\
\text { found }\end{array}$ & Yes $^{38}$ & $\begin{array}{l}\text { No information } \\
\text { found }\end{array}$ & $\begin{array}{l}\text { - Reimbursement status in other } \\
\text { European Union countries } \\
\text { - Estimated consumption } \\
\text { (number of patients and } \\
\text { utilization) })^{38}\end{array}$ \\
\hline $\begin{array}{l}\text { - Most commonly used } \\
\text { alternative OR } \\
\text { - Standard care }{ }^{139} \\
\text { Rationale must be provided }\end{array}$ & $\begin{array}{l}\text { Method not } \\
\text { specified }\end{array}$ & $\begin{array}{l}\text { No information } \\
\text { found }\end{array}$ & $\begin{array}{l}\text { No information } \\
\text { found }\end{array}$ & $\begin{array}{l}\text { No information } \\
\text { found }\end{array}$ & No information found \\
\hline
\end{tabular}

- Alternative most likely to be replaced OR

- Most commonly used alternative OR

- Most effective alternative OR

- Minimum management ${ }^{76}$

Rationale must be provided Following 3 comparators required:

- Most commonly used alternative

- Most recently reimbursed alternative

- Least expensive alternative ${ }^{16}$

\begin{tabular}{|c|c|c|c|c|}
\hline $\begin{array}{l}\text { Method not } \\
\text { specified }\end{array}$ & $\mathrm{Yes}^{76}$ & $Y_{e s}{ }^{161}$ & $\begin{array}{l}\text { No information } \\
\text { found }\end{array}$ & $\begin{array}{l}\text { - Market sales forecast } \\
\text { - Reimbursement status in other } \\
\text { European Union countries } \\
\text { - Estimated consumption (number } \\
\text { of patients and utilization) }{ }^{161}\end{array}$ \\
\hline $\begin{array}{l}\text { Method not } \\
\text { specified }\end{array}$ & $\begin{array}{l}\text { Yes for } \\
\text { pharmaceuticals }{ }^{22}\end{array}$ & $\mathrm{Yes}^{20}$ & $\begin{array}{l}\text { No information } \\
\text { found }\end{array}$ & $\begin{array}{l}\text { - Market sales forecast } \\
\text { - Reimbursement status in other } \\
\text { European Union countries } \\
\text { - Breakdown of costs } \\
\text { for manufacturing and } \\
\text { distribution } 22,162\end{array}$ \\
\hline
\end{tabular}


Table 4 (Continued)

\begin{tabular}{|c|c|c|c|c|}
\hline \multirow[t]{2}{*}{ Country } & \multirow{2}{*}{$\begin{array}{l}\text { Centralized reimbursement } \\
\text { review/decision-making } \\
\text { body (role) }\end{array}$} & \multicolumn{3}{|l|}{ Economic analysis } \\
\hline & & Required & $\begin{array}{l}\text { Economic analysis } \\
\text { types accepted }\end{array}$ & $\begin{array}{l}\text { Perspectivel } \\
\text { costs included }\end{array}$ \\
\hline Germany & $\begin{array}{l}\text { - Federal Joint Committee } \\
\text { (decisions) })^{19} \\
\text { - Institute for Quality and } \\
\text { Efficiency in Health Care } \\
\text { (recommendations) }^{19,24,144}\end{array}$ & $\begin{array}{l}\text { Yes for: } \\
\text { - Technologies where } \\
\text { alternative treatment exists }{ }^{8,18}\end{array}$ & $\begin{array}{l}\text { Any one of: } \\
\text { - Cost effectiveness } \\
\text { - Cost utility } \\
\text { - Cost minimization/ } \\
\text { cost comparison }{ }^{18} \\
\text { Efficiency frontier analysis }{ }^{12}\end{array}$ & $\begin{array}{l}\text { - Payer } \\
\text { - Patient } \\
\text { - Direct and } \\
\text { indirect costs }\end{array}$ \\
\hline Greece & $\begin{array}{l}\text { - Transparency Committee } \\
\text { in the Reimbursement and } \\
\text { Medicinal Products } \\
\text { (makes decisions) }^{85,160}\end{array}$ & $\begin{array}{l}\text { Yes for: } \\
\text { - Pharmaceuticals eligible for } \\
\text { reference price system }\end{array}$ & No information found & No information found \\
\hline Hungary & $\begin{array}{l}\text { - Ministers of Health and Finance } \\
\text { (decisions) } \\
\text { - National Health Insurance } \\
\text { Fund Administration } \\
\text { (recommendations) }^{86,90,102}\end{array}$ & $\mathrm{Yes}^{84}$ & $\begin{array}{l}\text { Preference for: } \\
\text { - Cost effectiveness } \\
\text { - Cost utility }{ }^{163}\end{array}$ & $\begin{array}{l}\text { - Payer } \\
\text { - Societal (also } \\
\text { recommended) } \\
\text { Report results from } \\
\text { each perspective } \\
\text { separately }{ }^{163}\end{array}$ \\
\hline Ireland & 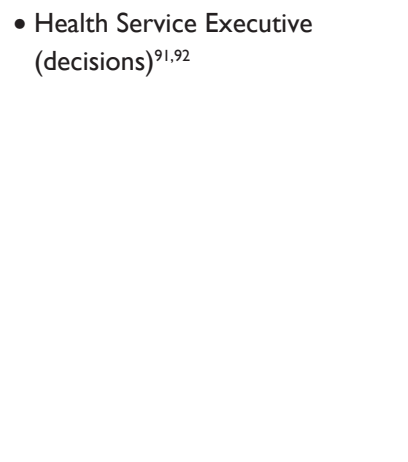 & $Y_{e s}^{146}$ & $\begin{array}{l}\text { Preference for: } \\
\text { - Cost utility }{ }^{10} \\
\text { Any one of the following } \\
\text { may be acceptable if } \\
\text { rationale is provided: } \\
\text { - Cost benefit } \\
\text { - Cost effectiveness } \\
\text { - Cost minimization/ } \\
\text { cost comparison }{ }^{147,165} \\
\text { - Methods must comply with } \\
\text { Irish Healthcare Technology } \\
\text { Assessment Guidelines }{ }^{146}\end{array}$ & $\begin{array}{l}\text { - Payer } \\
\text { - Direct costs } \\
\text { only }{ }^{147}\end{array}$ \\
\hline Italy & $\begin{array}{l}\text { - Italian Medicines Agency } \\
\text { Technical Scientific } \\
\text { Committee (decisions) } \\
\text { - Italian Medicines Agency Pricing } \\
\text { and Reimbursement Committee } \\
\text { (recommendations) }^{95}\end{array}$ & $\begin{array}{l}\text { Yes for: } \\
\text { - Pharmaceuticals with a } \\
\text { favorable "risk/benefit } \\
\text { profile" } 97,148\end{array}$ & $\begin{array}{l}\text { Preference for: } \\
\text { - Cost utility } \\
\text { - Cost effectiveness }{ }^{148} \\
\text { - Methods must } \\
\text { comply with Italian } \\
\text { pharmacoeconomic } \\
\text { guidelines }^{148}\end{array}$ & $\begin{array}{l}\text { - Societal AND } \\
\text { - Payer }{ }^{148} \\
\text { - Direct and } \\
\text { indirect costs }{ }^{148}\end{array}$ \\
\hline Norway & $\begin{array}{l}\text { - Norwegian Medicines } \\
\text { Agency (decisions) } \\
\text { - Department of Pharmaco } \\
\text { economics (recommendations) }\end{array}$ & $\begin{array}{l}\text { Yes for: } \\
\text { - Pharmaceuticals with added } \\
\text { therapeutic value relative to } \\
\text { existing alternatives }{ }^{34}\end{array}$ & $\begin{array}{l}\text { Preference for: } \\
\text { - Cost-value analysis }{ }^{150} \\
\text { Any one of the following } \\
\text { may be acceptable if } \\
\text { rationale is provided: } \\
\text { - Cost benefit } \\
\text { - Cost effectiveness } \\
\text { - Cost utility } \\
\text { - Cost consequence } \\
\text { - Cost minimization/ } \\
\text { cost comparison }{ }^{34} \\
\text { - Methods must comply } \\
\text { with Norwegian } \\
\text { pharmacoeconomic } \\
\text { guidelines }{ }^{34}\end{array}$ & $\begin{array}{l}\text { - Societal AND } \\
\text { - Payer }\end{array}$ \\
\hline
\end{tabular}




\begin{tabular}{|c|c|c|c|c|c|}
\hline \multirow[b]{2}{*}{ Comparator } & \multirow[b]{2}{*}{$\begin{array}{l}\text { Sensitivity } \\
\text { analysis }\end{array}$} & \multirow[b]{2}{*}{$\begin{array}{l}\text { Systematic review } \\
\text { of economic } \\
\text { analysis studies }\end{array}$} & \multicolumn{2}{|c|}{ Budget impact analysis } & \multirow{2}{*}{$\begin{array}{l}\text { Other economic } \\
\text { information }\end{array}$} \\
\hline & & & Required & $\begin{array}{l}\text { Costs } \\
\text { included }\end{array}$ & \\
\hline $\begin{array}{l}\text { - Most commonly used } \\
\text { alternative OR } \\
\text { - Most effective alternative } \\
\text { OR } \\
\text { - Minimum standard care }\end{array}$ & $\begin{array}{l}\text { One-way and } \\
\text { multi-way } \\
\text { (performed as } \\
\text { probabilistic) }^{24}\end{array}$ & Yes $^{84}$ & $\begin{array}{l}\text { Yes, except } \\
\text { when } \\
\text { no alternative } \\
\text { exists }^{18}\end{array}$ & $\begin{array}{l}\text { No information } \\
\text { found }\end{array}$ & No information found \\
\hline No information found & $\begin{array}{l}\text { No information } \\
\text { found }\end{array}$ & $\begin{array}{l}\text { No information } \\
\text { found }\end{array}$ & Yes $^{85}$ & $\begin{array}{l}\text { No information } \\
\text { found }\end{array}$ & $\begin{array}{l}\text { - Cost of daily treatment } \\
\text { - Reimbursement status in other } \\
\text { European Union countries }{ }^{85}\end{array}$ \\
\hline - Standard care ${ }^{163}$ & $\begin{array}{l}\text { Yes, but type } \\
\text { not specified }{ }^{163}\end{array}$ & $\begin{array}{l}\text { No information } \\
\text { found }\end{array}$ & $Y_{e s}{ }^{84}$ & $\begin{array}{l}\text { - If payer } \\
\text { perspective, } \\
\text { include direct } \\
\text { costs only } \\
\text { - If societal } \\
\text { perspective, } \\
\text { include } \\
\text { indirect costs } \\
\text { (productivity) }^{163}\end{array}$ & No information found \\
\hline - Standard care ${ }^{125}$ & $\begin{array}{l}\text { Probabilistic and } \\
\text { deterministic }^{125}\end{array}$ & $\begin{array}{l}\text { No information } \\
\text { found }\end{array}$ & Yes & $\begin{array}{l}\text { - Direct costs } \\
\text { only }^{91,147}\end{array}$ & No information found \\
\hline
\end{tabular}

- Most commonly used alternative $^{148}$
Methods not specified, but should involve multi-way analysis $^{148}$

Probabilistic preferred ${ }^{150}$

No information $\quad$ Yes $^{148}$
found

No information

found

$\begin{array}{ll}\text { Yes' }^{149} & \text { No information } \\ \text { Aggregate } & \text { found } \\ \text { added } & \\ \text { expense to } & \\ \text { health service } & \\ \text { for first } & \\ 5 \text { years }^{149} & \end{array}$

$\begin{array}{ll}\text { No information } & \text { - } \text { Cost of treatment compared to } \\ \text { found } & \text { those in same therapeutic class } \\ & \text { - Market sales forecast } \\ & \text { - Price in other European Union } \\ & \text { countries } \\ & \text { - Reimbursement status in other } \\ & \text { European Union countries } \\ & \text { - Estimated consumption (number } \\ & \text { of patients and utilization) } \\ \text { - Industrial implications } & 97 \\ \text { - } & \text { Market sales forecast } \\ \text { - Price in other European Union } & \text { countries } \\ \text { No information } & \text { - Reimbursement status in other } \\ \text { found } & \text { European Union countries } \\ & \text { - Estimated consumption (number } \\ & \text { of patients and utilization) }\end{array}$


Table 4 (Continued)

\begin{tabular}{|c|c|c|c|c|}
\hline \multirow[t]{2}{*}{ Country } & \multirow{2}{*}{$\begin{array}{l}\text { Centralized reimbursement } \\
\text { review/decision-making } \\
\text { body (role) }\end{array}$} & \multicolumn{3}{|l|}{ Economic analysis } \\
\hline & & Required & $\begin{array}{l}\text { Economic analysis } \\
\text { types accepted }\end{array}$ & $\begin{array}{l}\text { Perspectivel } \\
\text { costs included }\end{array}$ \\
\hline Poland & $\begin{array}{l}\text { - Ministry of Health } \\
\text { (decisions) }^{99,166}\end{array}$ & $\begin{array}{l}\text { Yes for: } \\
\text { - Pharmaceuticals with added } \\
\text { therapeutic value relative } \\
\text { to existing alternatives }{ }^{84}\end{array}$ & $\begin{array}{l}\text { - Cost effectiveness } \\
\text { - Cost utility }{ }^{84}\end{array}$ & $\begin{array}{l}\text { - Societal AND } \\
\text { - Payer }\end{array}$ \\
\hline Portugal & $\begin{array}{l}\text { - Ministry of Health (decisions) } \\
\text { - INFARMED } \\
\text { (recommendations) })^{64,160}\end{array}$ & $Y_{e s}^{44,160}$ & $\begin{array}{l}\text { Any one of : } \\
\text { - Cost benefit } \\
\text { - Cost effectiveness } \\
\text { - Cost utility } \\
\text { - Cost minimization/ } \\
\text { cost comparison; } \\
\text { rationale for selection } \\
\text { must be provided }{ }^{101}\end{array}$ & $\begin{array}{l}\text { - Societal } \\
\text { - Direct costs } \\
\text { - Indirect costs: } \\
\text { only those } \\
\text { related to lost } \\
\text { productivity }^{101}\end{array}$ \\
\hline Scotland & $\begin{array}{l}\text { - National Health Service } \\
\text { Scotland (decisions) }{ }^{30} \\
\text { - Scottish Medicines Consortium } \\
\text { (recommendations) }\end{array}$ & $Y_{e s}{ }^{168}$ & $\begin{array}{l}\text { Any one of : } \\
\text { - Cost benefit } \\
\text { - Cost effectiveness } \\
\text { - Cost utility } \\
\text { - Cost minimization/ } \\
\text { cost comparison; } \\
\text { rationale for selection } \\
\text { must be provided }{ }^{168} \\
\text { - Methods must comply } \\
\text { with SMC economic } \\
\text { guidelines }\end{array}$ & - Payer $^{30}$ \\
\hline Slovakia & $\begin{array}{l}\text { - Ministry of Health (decisions) } \\
\text { - Reimbursement Committee } \\
\text { for Medicinal Products } \\
\text { (recommendations) }^{105,107}\end{array}$ & Yes $^{105,106}$ & $\begin{array}{l}\text { - Cost effectiveness } \\
\text { - Cost utility } \\
\text { (if pharmaceutical has } \\
\text { impact on quality of life) } \\
\text { - Cost minimization/ } \\
\text { cost comparison } \\
\text { - Cost benefit not } \\
\text { accepted }{ }^{169} \\
\text { Methods should comply } \\
\text { with national economic } \\
\text { guidelines }{ }^{170}\end{array}$ & $\begin{array}{l}\text { - } \text { Payer }^{169} \\
\text { - Direct costs }\end{array}$ \\
\hline Spain & $\begin{array}{l}\text { - Ministry of Health Directorate } \\
\text { General of Pharmacy and } \\
\text { Health Products; Inter- } \\
\text { Ministerial Pricing Commission } \\
\text { (decisions) })^{21,108,171}\end{array}$ & $\mathrm{No}^{21}$ & $\begin{array}{l}\text { Preference for: } \\
\text { - Cost effectiveness } \\
\text { - Cost utility }{ }^{10,21} \\
\text { Any one of the } \\
\text { following may be } \\
\text { acceptable if rationale } \\
\text { is provided: } \\
\text { - Cost benefit } \\
\text { - Cost effectiveness } \\
\text { - Cost utility } \\
\text { - Cost consequence } \\
\text { - Cost minimization/ } \\
\text { cost comparison }{ }^{10}\end{array}$ & $\begin{array}{l}\text { - Societal AND } \\
\text { - Payer }{ }^{10} \\
\text { Presented } \\
\text { separately }\end{array}$ \\
\hline
\end{tabular}




\begin{tabular}{|c|c|c|c|c|c|}
\hline \multirow[b]{2}{*}{ Comparator } & \multirow[b]{2}{*}{$\begin{array}{l}\text { Sensitivity } \\
\text { analysis }\end{array}$} & \multirow[b]{2}{*}{$\begin{array}{l}\text { Systematic review } \\
\text { of economic } \\
\text { analysis studies }\end{array}$} & \multicolumn{2}{|c|}{ Budget impact analysis } & \multirow{2}{*}{$\begin{array}{l}\text { Other economic } \\
\text { information }\end{array}$} \\
\hline & & & Required & $\begin{array}{l}\text { Costs } \\
\text { included }\end{array}$ & \\
\hline $\begin{array}{l}\text { - Alternative most likely } \\
\text { to be replaced OR } \\
\text { - Most commonly used } \\
\text { alternative OR } \\
\text { - Least expensive alternative } \\
\text { OR } \\
\text { - Standard care compliant } \\
\text { with clinical practice } \\
\text { guidelines } \\
\text { (51 }\end{array}$ & $\begin{array}{l}\text { Methods not } \\
\text { specified }\end{array}$ & $\begin{array}{l}\text { No information } \\
\text { found }\end{array}$ & Yes $^{84}$ & $\begin{array}{l}\text { No information } \\
\text { found }\end{array}$ & No information found \\
\hline $\begin{array}{l}\text { - Most commonly used } \\
\text { alternative } \\
\text { - Standard care } \\
\end{array}$ & $\begin{array}{l}\text { Methods not } \\
\text { specified }\end{array}$ & $\begin{array}{l}\text { No information } \\
\text { found }\end{array}$ & No101 & $\mathrm{N} / \mathrm{A}$ & No information found \\
\hline $\begin{array}{l}\text { - Alternative most likely } \\
\text { to be replaced OR } \\
\text { - Most commonly used } \\
\text { alternative }^{30}\end{array}$ & Probabilistic ${ }^{168}$ & $\begin{array}{l}\text { No information } \\
\text { found }\end{array}$ & Yes $^{30}$ & $\begin{array}{l}\text { No information } \\
\text { found }\end{array}$ & $\begin{array}{l}\text { - National Health Service } \\
\text { resource implications }{ }^{30}\end{array}$ \\
\hline $\begin{array}{l}\text { - Alternative most likely } \\
\text { to be replaced } \\
\text { - If add-on: current } \\
\text { treatment without add-on }{ }^{152}\end{array}$ & Probabilistic ${ }^{106,152}$ & Yes $^{152}$ & $\begin{array}{l}\text { Yes } \\
\text { Estimated over } \\
\text { first } 5 \text { years }^{84}\end{array}$ & $\begin{array}{l}\text { No information } \\
\text { found }\end{array}$ & No information found \\
\hline $\begin{array}{l}\text { - Most commonly used } \\
\text { alternative } \\
\text { - Standard care }{ }^{10}\end{array}$ & Multi-way ${ }^{10}$ & $\begin{array}{l}\text { No information } \\
\text { found }\end{array}$ & $\begin{array}{l}\text { Yes, comparing } \\
\text { "corresponding } \\
\text { products"।0 }\end{array}$ & $\begin{array}{l}\text { No information } \\
\text { found }\end{array}$ & No information found \\
\hline
\end{tabular}


Table 4 (Continued)

\begin{tabular}{|c|c|c|c|c|}
\hline \multirow[t]{2}{*}{ Country } & \multirow{2}{*}{$\begin{array}{l}\text { Centralized reimbursement } \\
\text { review/decision-making } \\
\text { body (role) }\end{array}$} & \multicolumn{3}{|l|}{ Economic analysis } \\
\hline & & Required & $\begin{array}{l}\text { Economic analysis } \\
\text { types accepted }\end{array}$ & $\begin{array}{l}\text { Perspectivel } \\
\text { costs included }\end{array}$ \\
\hline Sweden & $\begin{array}{l}\text { - Dental and Pharmaceutical } \\
\text { Benefits Board (decisions) }{ }^{15,109}\end{array}$ & Yes, if requested ${ }^{21}$ & $\begin{array}{l}\text { Any one of: } \\
\text { - Cost effectiveness } \\
\text { - Cost utility } \\
\text { - Cost minimization/ } \\
\text { cost comparison; } \\
\text { rationale for selection } \\
\text { must be provided }{ }^{15} \\
\text { - Methods must comply } \\
\text { with Swedish economic } \\
\text { guidelines }\end{array}$ & $\begin{array}{l}\text { - Societal } \\
\text { - Direct costs } \\
\text { - Indirect costs: } \\
\text { lost productivity } \\
\text { and lost time } \\
\text { for patients and } \\
\text { carers } \\
14,15\end{array}$ \\
\hline Switzerland & $\begin{array}{l}\text { - Swiss Federal Office of Public } \\
\text { Health (decisions) } \\
\text { - Federal Drug Commission } \\
\text { (recommendations) }^{1 / 3,1 / 4}\end{array}$ & $\begin{array}{l}\text { No, but should be included } \\
\text { if available }{ }^{115,172}\end{array}$ & No information found & No information found \\
\hline The Netherlands & $\begin{array}{l}\text { - Ministry of Health, Welfare } \\
\text { and Sport (decisions) } \\
\text { - Medicinal Products } \\
\text { Reimbursement Committee } \\
\text { of the Dutch Healthcare } \\
\text { Insurance Board } \\
\text { (recommendations) }\end{array}$ & $\begin{array}{l}\text { Yes for pharmaceuticals } \\
\text { with added therapeutic value } \\
\text { (Annex IB), except for orphan } \\
\text { pharmaceuticals with small } \\
\text { budget impact or absence } \\
\text { of active alternative }\end{array}$ & $\begin{array}{l}\text { - Cost effectiveness } \\
\text { - Cost utility } \\
\text { - Methods must } \\
\text { comply with Dutch } \\
\text { Healthcare Insurance } \\
\text { Board economic } \\
\text { guidelines } \\
36,84,173\end{array}$ & $\begin{array}{l}\text { - Societal } \\
\text { - Direct costs } \\
\text { - Indirect costs } \\
\text { may be included } \\
\text { but must be } \\
\text { reported } \\
\text { separately }^{154}\end{array}$ \\
\hline $\begin{array}{l}\text { United } \\
\text { Kingdom }\end{array}$ & $\begin{array}{l}\text { - National Institute for Health } \\
\text { and Clinical Excellence } \\
\text { (decisions) } \\
\text { - Technology Appraisals } \\
\text { Committee (recommendations) }\end{array}$ & Yes $^{7}$ & $\begin{array}{l}\text { - Cost effectiveness } \\
\text { - Cost utility } \\
\text { - Methods must comply } \\
\text { with National Institute } \\
\text { for Health and Clinical } \\
\text { Excellence economic } \\
\text { guidelines }^{13,157}\end{array}$ & $\begin{array}{l}\text { - Payer } \\
\text { - Direct and } \\
\text { indirect costs to } \\
\text { National Health } \\
\text { Service and } \\
\text { Personal Social } \\
\text { Services }\end{array}$ \\
\hline Wales & $\begin{array}{l}\text { - Ministry for Health and Social } \\
\text { Services (decisions) } \\
\text { - All Wales Medicines Strategy } \\
\text { Group (recommendations) }\end{array}$ & Yes $^{174}$ & $\begin{array}{l}\text { Any one of: } \\
\text { - Cost effectiveness } \\
\text { - Cost utility } \\
\text { - Cost minimization/ } \\
\text { cost comparison; } \\
\text { rationale for selection } \\
\text { must be provided }{ }^{28,174} \\
\text { - Methods must comply } \\
\text { with economic } \\
\text { guidelines }{ }^{28,174}\end{array}$ & - Societal ${ }^{28}$ \\
\hline
\end{tabular}

score to the candidate technology (a new pharmaceutical). The score is based on a five-point scale, with "I" representing "major medical benefit" and "V" representing "insufficient to justify reimbursement." ${ }^{16,20-23}$ Upon approval of the score by the Minister, the CEM then compares the technology with already reimbursed alternatives in order to formulate an opinion on the "improvement in medical benefit" or "ASMR" level. Six possible levels exist, ranging from I (major innovation) to VI (negative opinion regarding inclusion on the benefit list). Therefore, "innovativeness" is viewed as the size of the incremental clinical benefit achieved by the candidate technology. The opinion of the CEM is forwarded to the Transparency Commission, who makes a formal recommendation on the ASMR classification. This classification is, in turn, used to negotiate price and reimbursement rate. In Germany, the "innovativeness" of a technology is also based on whether it offers "added therapeutic value." Moreover, it plays an important role in determining the content of subsequent committee deliberations, because "cost-benefit" analyses are only taken into account when a technology has been deemed 


\begin{tabular}{|c|c|c|c|c|c|}
\hline \multirow[b]{2}{*}{ Comparator } & \multirow[b]{2}{*}{$\begin{array}{l}\text { Sensitivity } \\
\text { analysis }\end{array}$} & \multirow[b]{2}{*}{$\begin{array}{l}\text { Systematic review } \\
\text { of economic } \\
\text { analysis studies } \\
\end{array}$} & \multicolumn{2}{|c|}{ Budget impact analysis } & \multirow{2}{*}{$\begin{array}{l}\text { Other economic } \\
\text { information }\end{array}$} \\
\hline & & & Required & $\begin{array}{l}\text { Costs } \\
\text { included }\end{array}$ & \\
\hline $\begin{array}{l}\text { - Most commonly used } \\
\text { alternative }^{15}\end{array}$ & Not specified & $\begin{array}{l}\text { No information } \\
\text { found }\end{array}$ & & & $\begin{array}{l}\text { - Estimated average } \\
\text { duration of use } \\
\text { - Estimated consumption (number } \\
\text { of patients and utilization) } \\
\text { - Estimated cost of use per day }{ }^{15}\end{array}$ \\
\hline No information found & $\begin{array}{l}\text { No information } \\
\text { found }\end{array}$ & $\begin{array}{l}\text { No information } \\
\text { found }\end{array}$ & Yes $^{115,172}$ & $\begin{array}{l}\text { No information } \\
\text { found }\end{array}$ & $\begin{array}{l}\text { - Price in other European Union } \\
\text { countries } \\
\text { - Reimbursement status in other } \\
\text { European Union countries } \\
\text { - Estimated cost of use per } \\
\text { day }{ }^{115,172}\end{array}$ \\
\hline $\begin{array}{l}\text { - Most commonly used } \\
\text { alternative OR } \\
\text { - Most relevant reimbursed } \\
\text { alternative }{ }^{84,173}\end{array}$ & $\begin{array}{l}\text { One-way, } \\
\text { multi-way, and } \\
\text { probabilistic }^{35}\end{array}$ & $\begin{array}{l}\text { No information } \\
\text { found }\end{array}$ & Yes $^{154}$ & $\begin{array}{l}\text { No information } \\
\text { found }\end{array}$ & $\begin{array}{l}\text { - Anticipated substitution effects } \\
\text { - Price } \\
\text { - Estimated consumption (number } \\
\text { of patients and utilization) })^{154}\end{array}$ \\
\hline $\begin{array}{l}\text { - Most commonly used } \\
\text { alternative OR } \\
\text { - Best practice alternative }{ }^{13,157}\end{array}$ & Probabilistic $^{157}$ & Yes $^{13,157}$ & Yes $^{13,157}$ & $\begin{array}{l}\text { No information } \\
\text { found }\end{array}$ & $\begin{array}{l}\text { - National Health Service } \\
\text { resource implications }{ }^{3,1,157}\end{array}$ \\
\hline $\begin{array}{l}\text { - Most commonly used } \\
\text { alternative }{ }^{28}\end{array}$ & Probabilistic $^{28}$ & Yes $^{28}$ & $Y_{e s}^{28,174}$ & $\begin{array}{l}\text { No information } \\
\text { found }\end{array}$ & $\begin{array}{l}\text { - National Health Service } \\
\text { resource implications }{ }^{28,174}\end{array}$ \\
\hline
\end{tabular}

innovative. ${ }^{18-24}$ The review committee of the Italian Medicines Agency, ie, the Technical Scientific Committee, explicitly weighs both the availability of existing treatments and the extent of clinical benefit in its assessment of a new pharmaceutical's innovativeness. The two attributes are scored separately and then combined to determine whether it represents an "important," "moderate," or "modest" innovation..$^{25}$ This rating, along with the category of clinical value to which the pharmaceutical has been assigned, is sent to a second review committee, ie, the Pricing and Reimbursement Committee, which negotiates price and reimbursement status with the manufacturer. ${ }^{26,27}$

Regardless of the reimbursement system, one of the main goals of the review committee is to determine the "therapeutic value" of a candidate technology. Broadly, its assessment combines consideration of clinical benefit with that of clinical need, taking into account key factors related to each dimension. For clinical need, they comprise, at a minimum, burden of illness (prevalence of severity) of the target condition and availability of alternatives. For clinical benefit, 


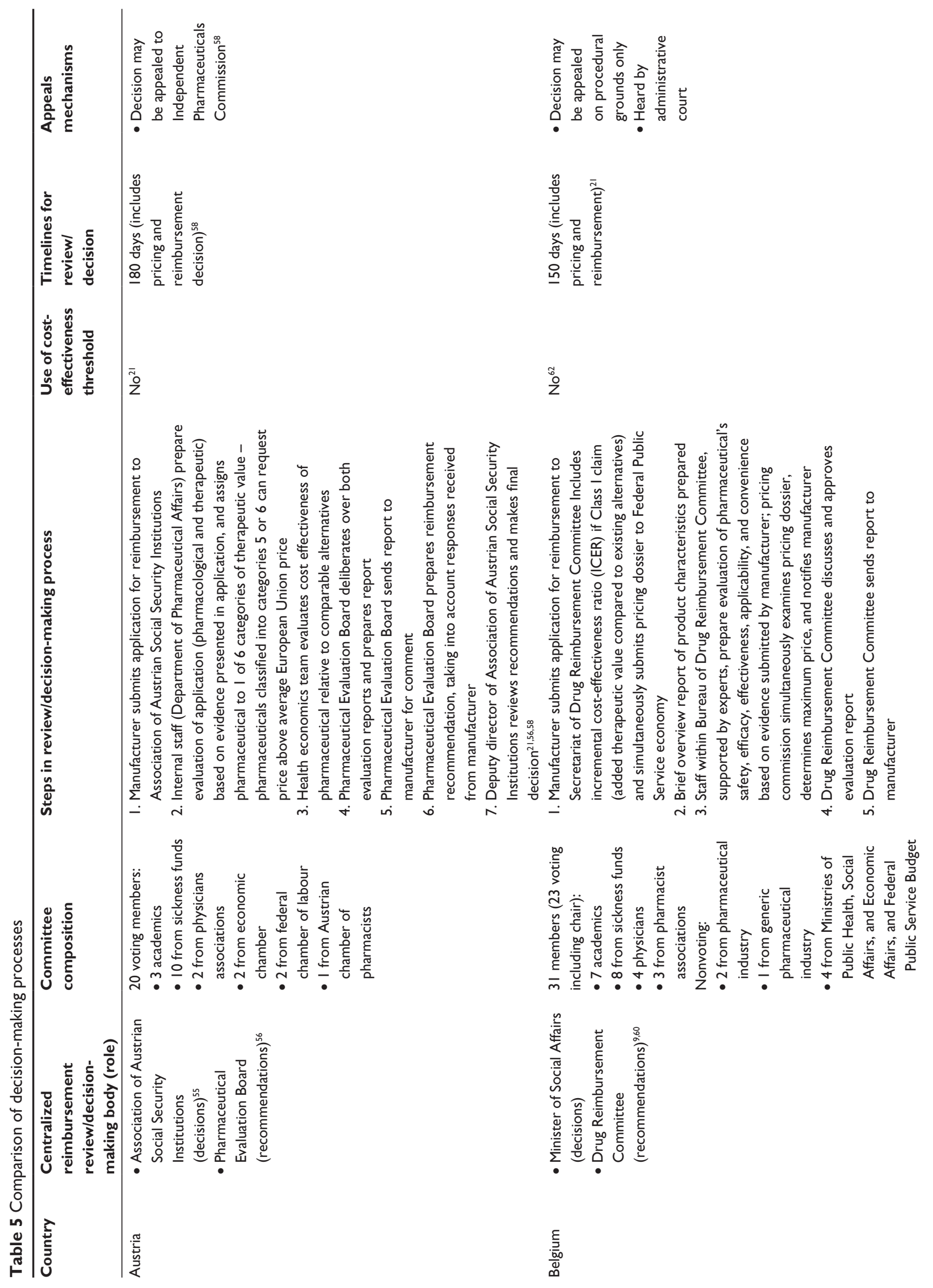



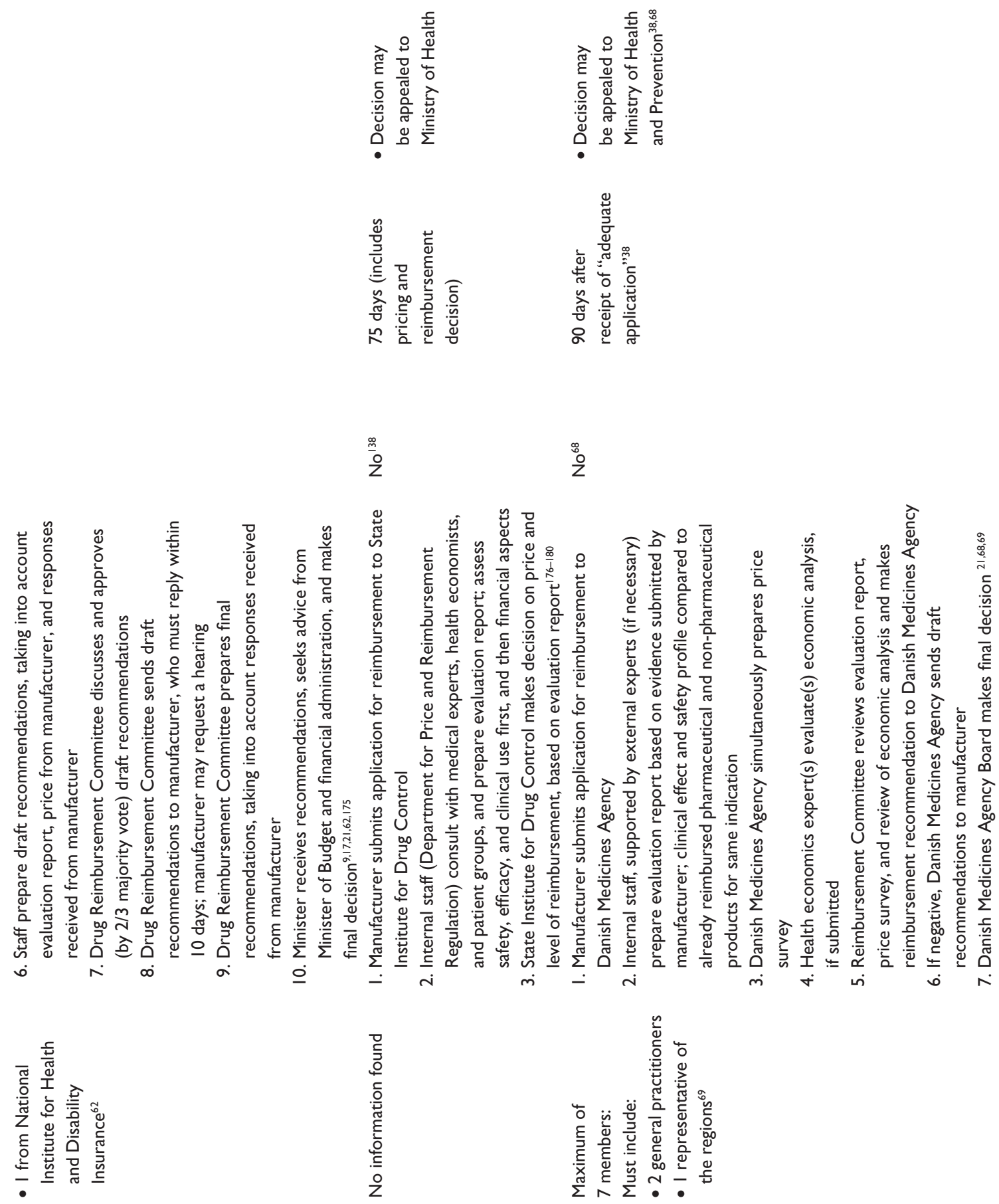

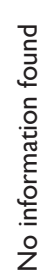
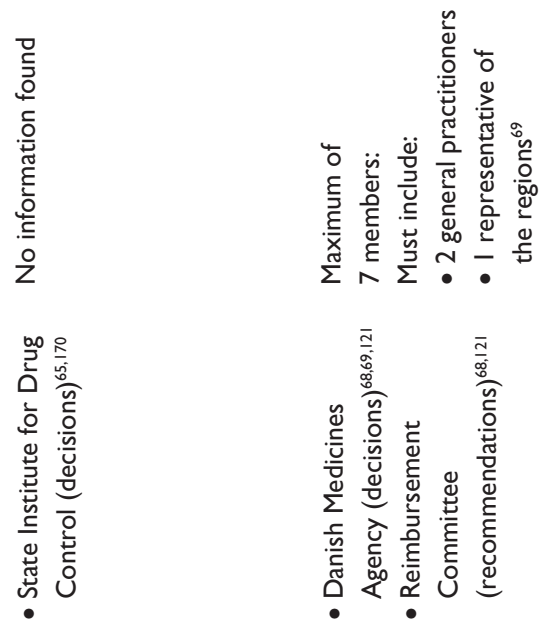

芯<smiles>[CH]=[Ge]</smiles> 


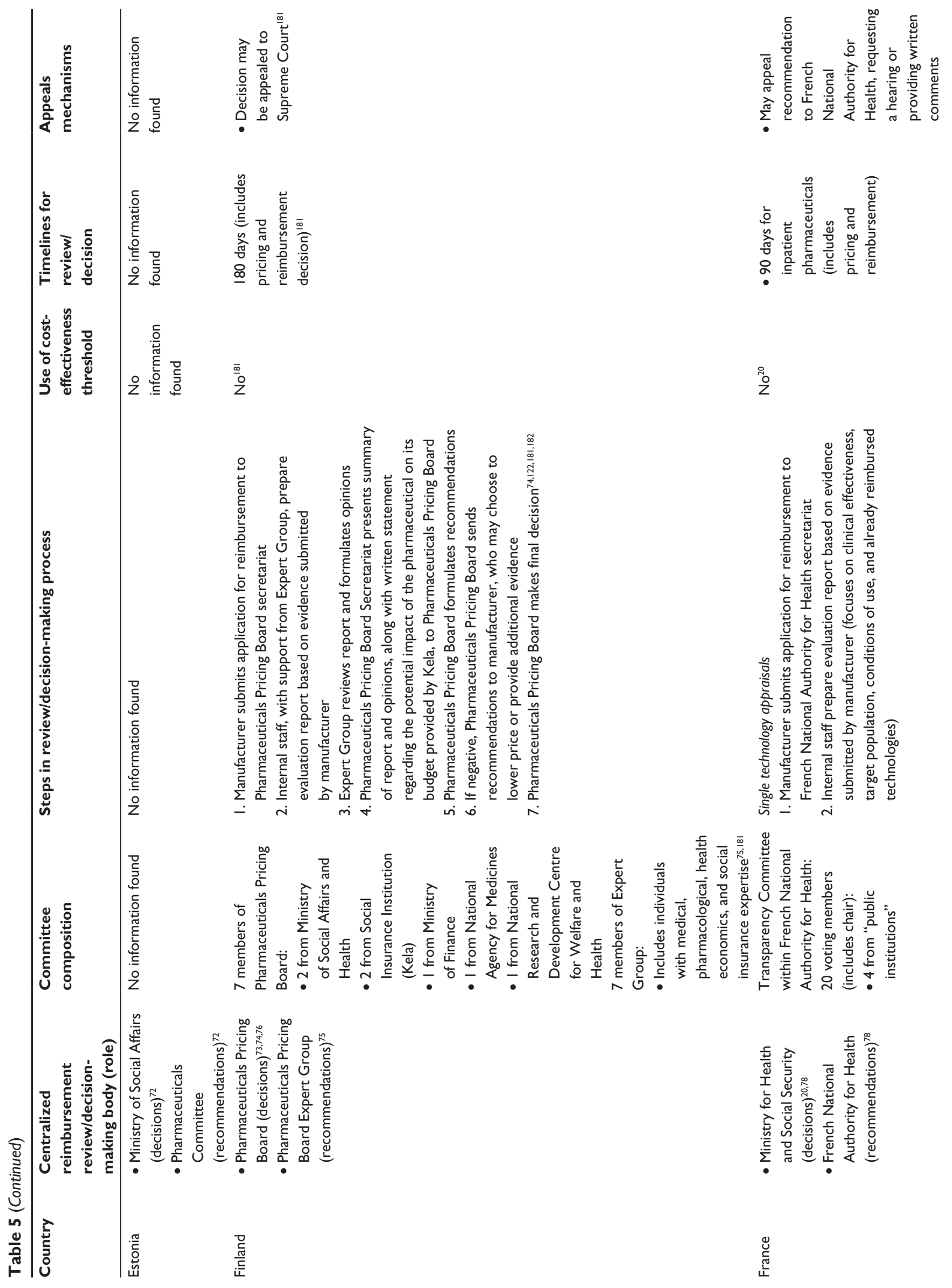




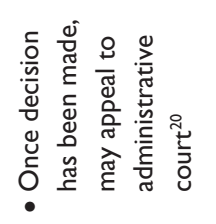
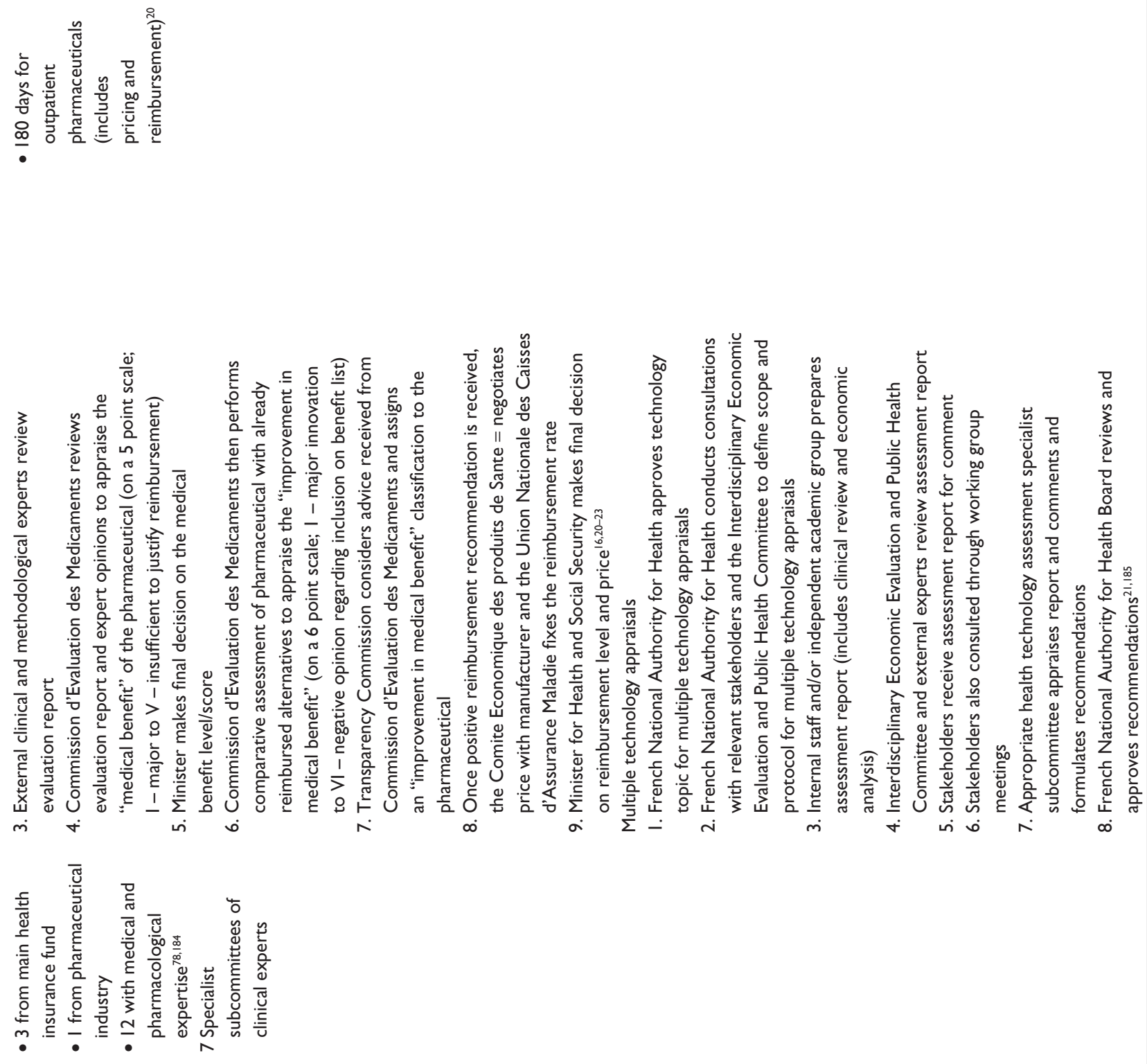


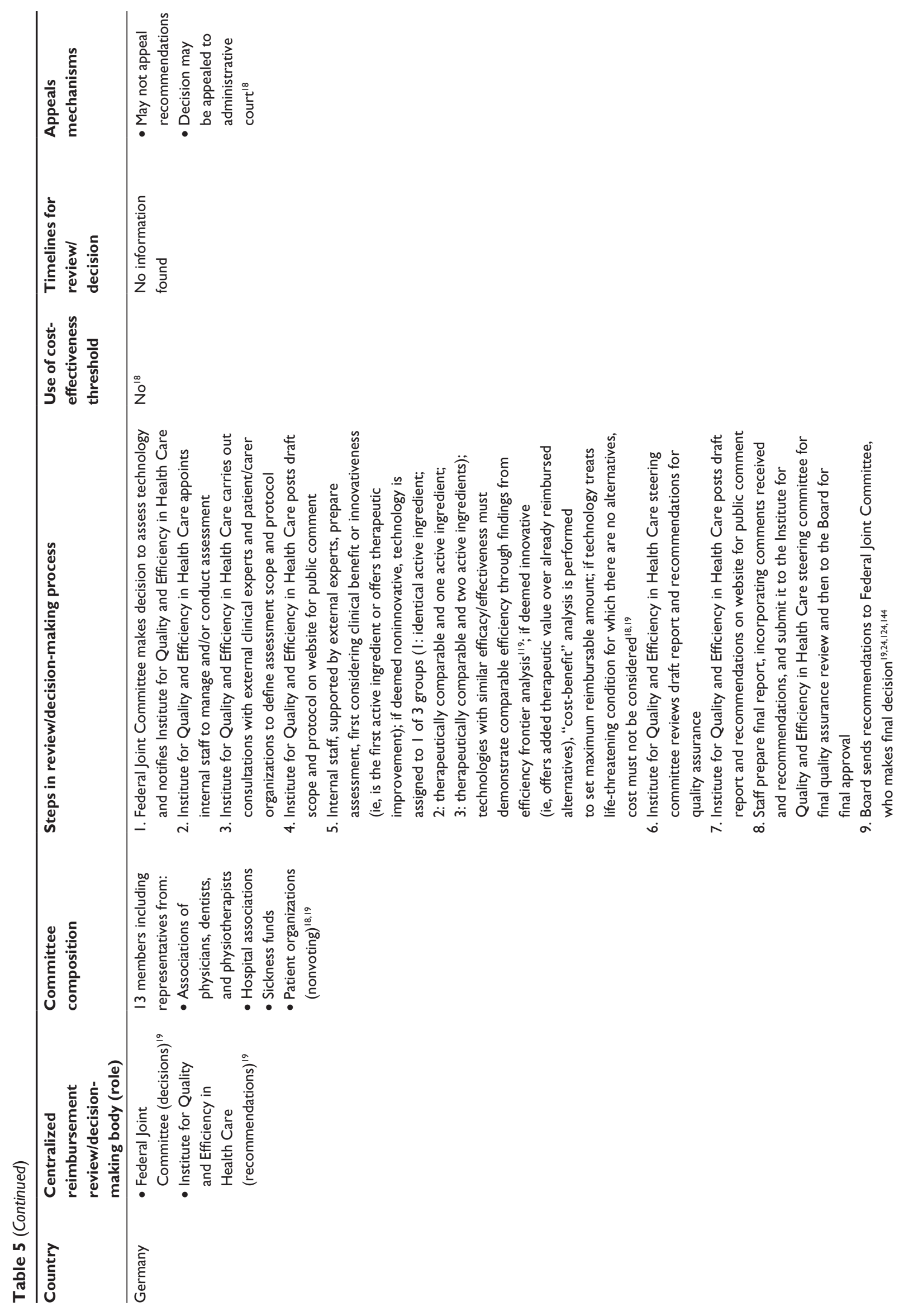




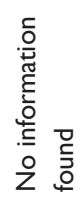

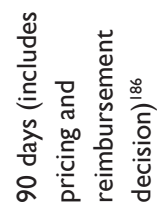

Z․ำ

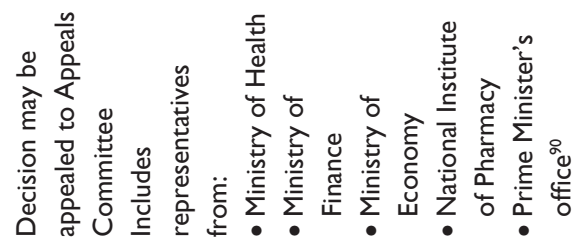

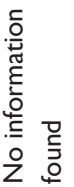

そำ

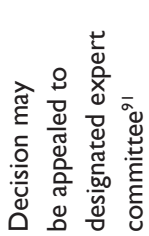

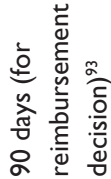

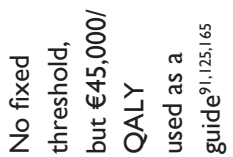

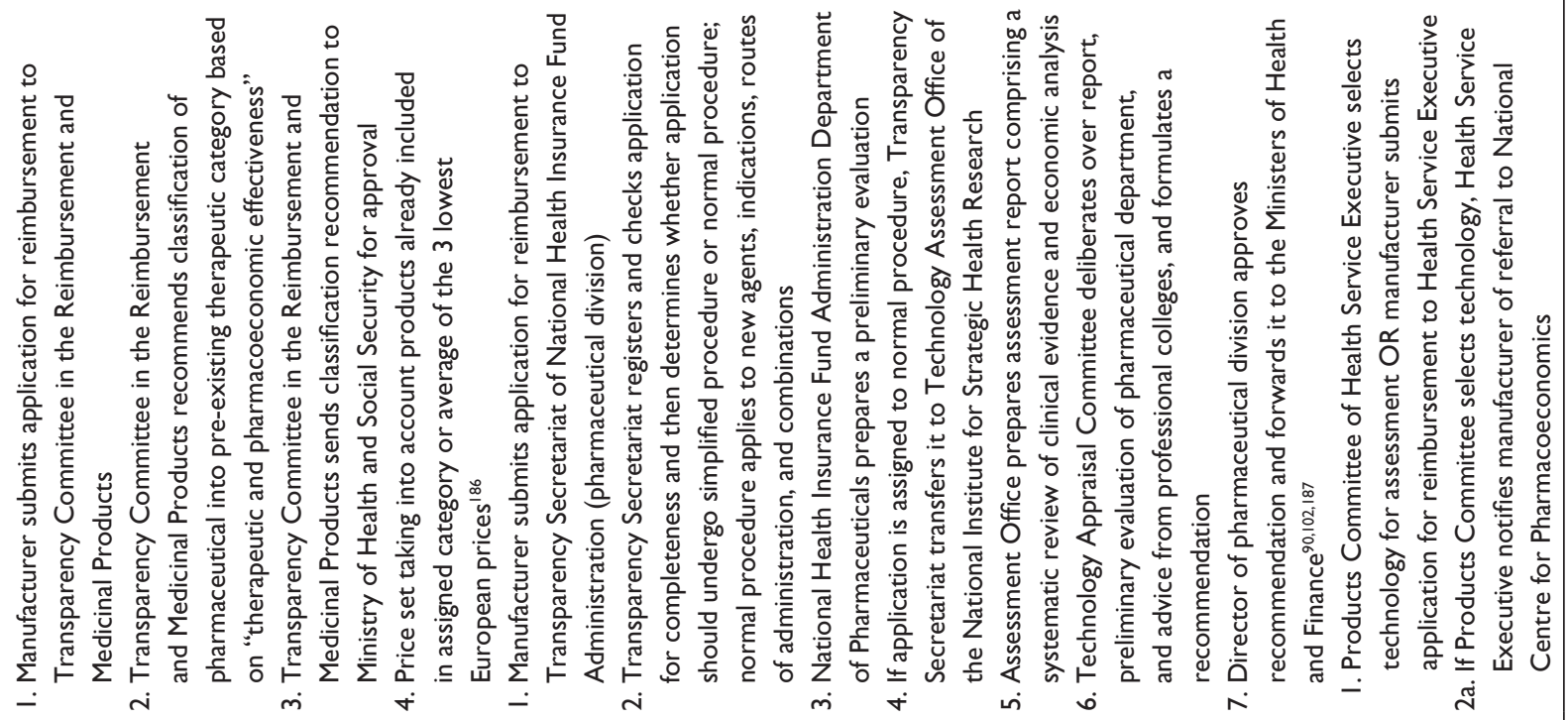
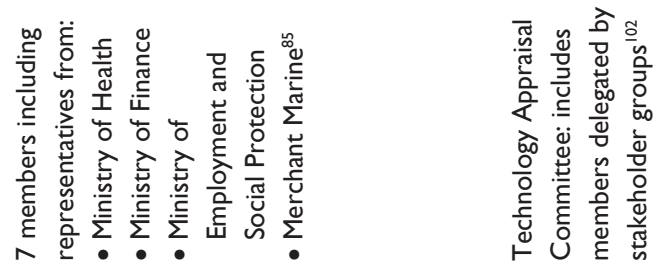

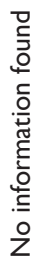
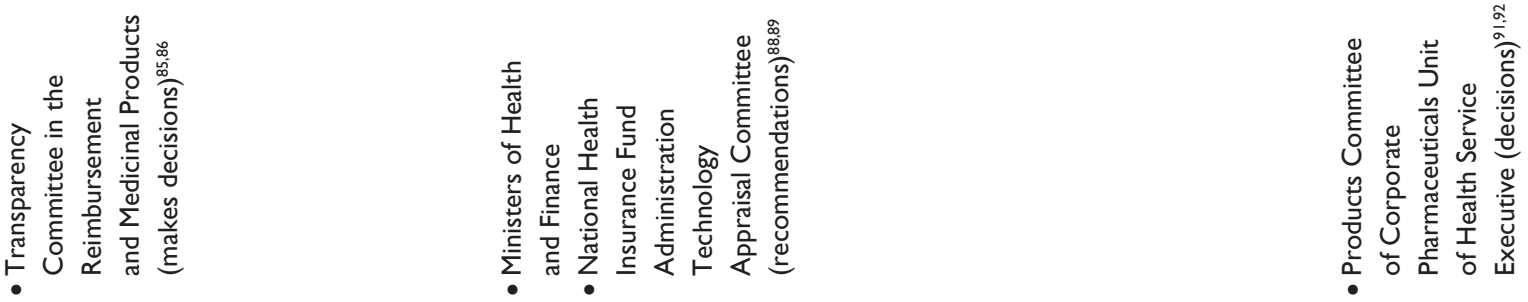

ષัँ

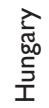

$\underset{\underline{\underline{0}}}{\underline{\underline{0}}}$ 


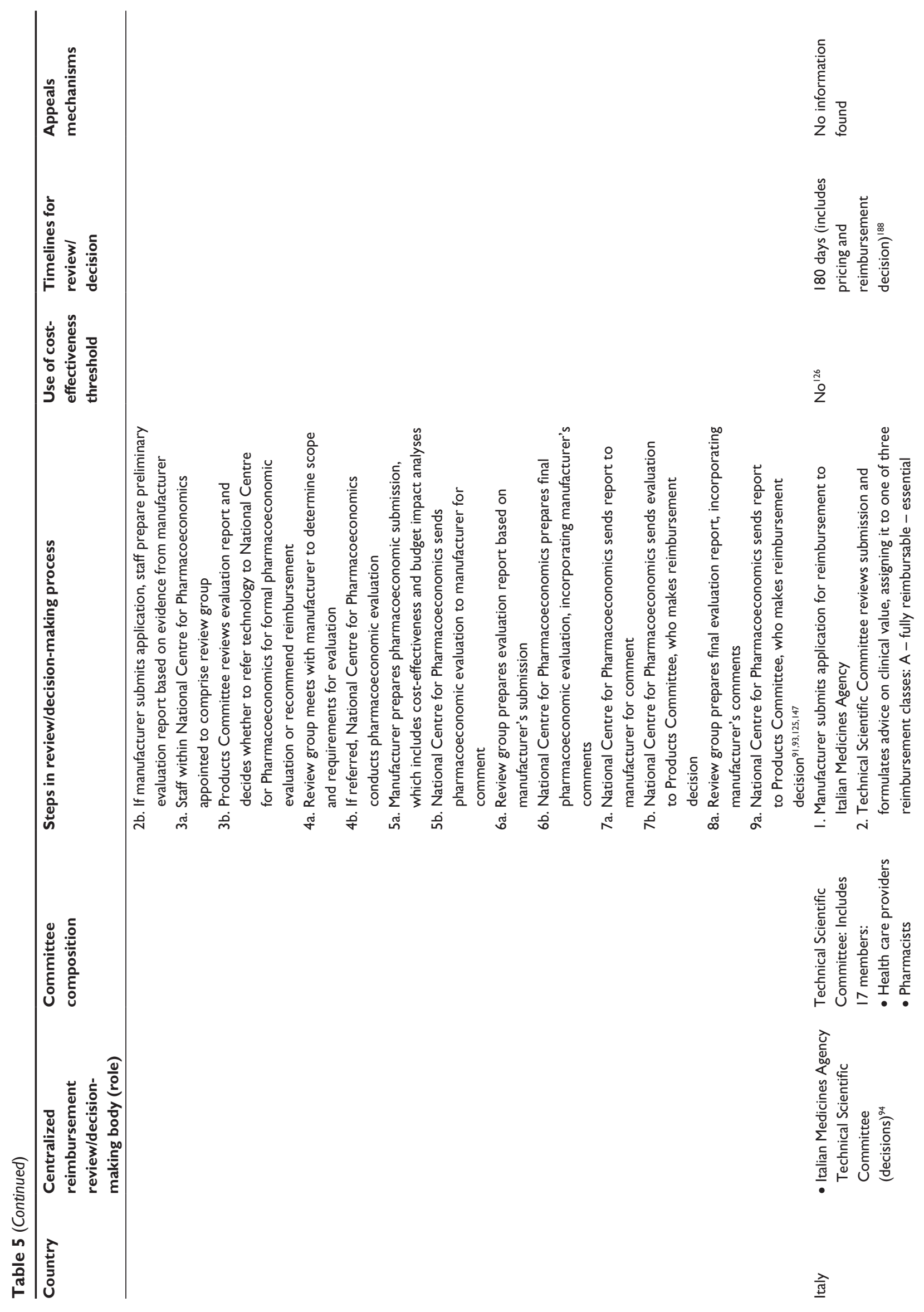




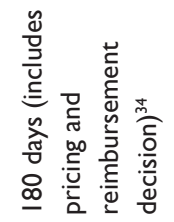

范
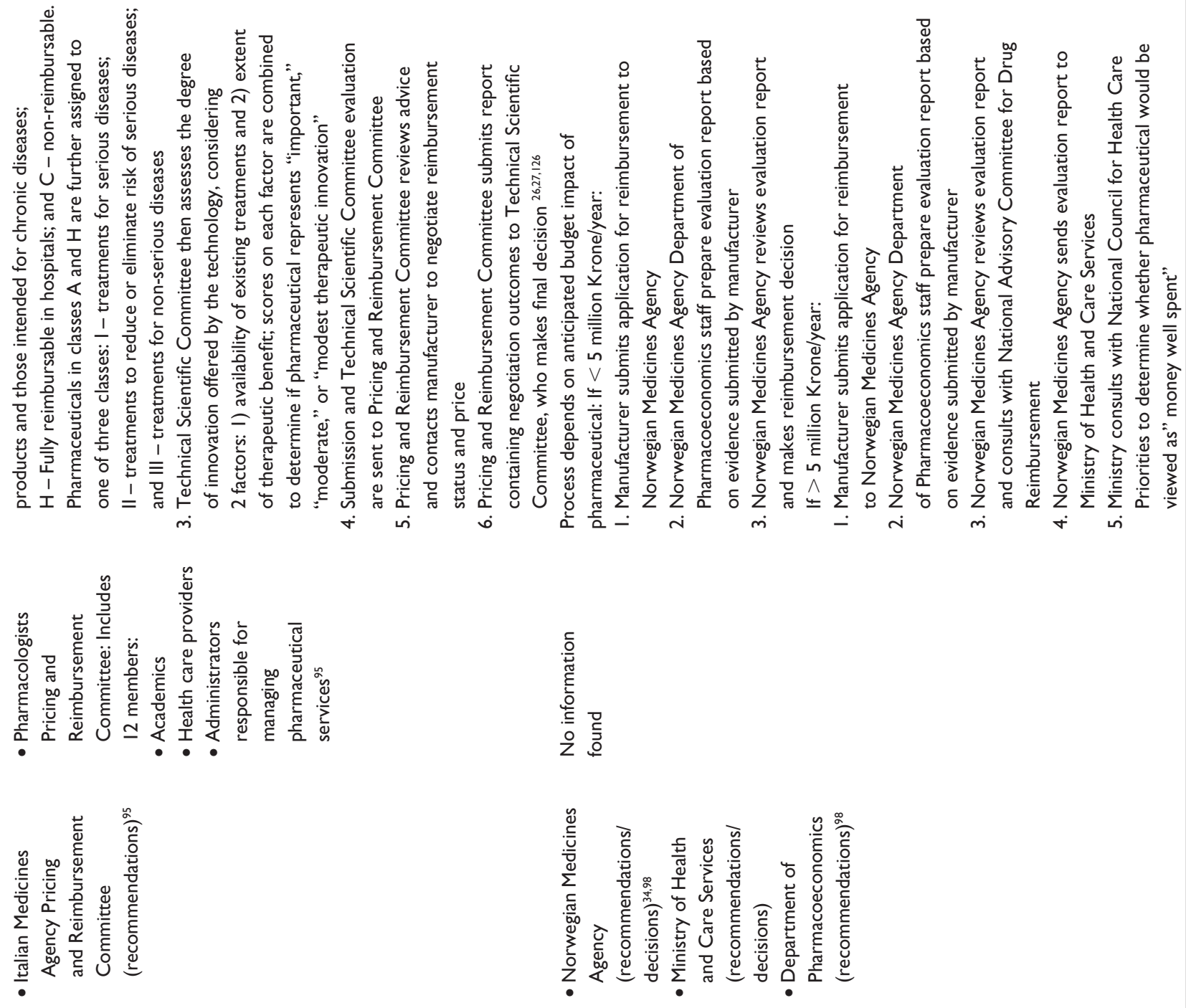

$\frac{\lambda}{3}$ 


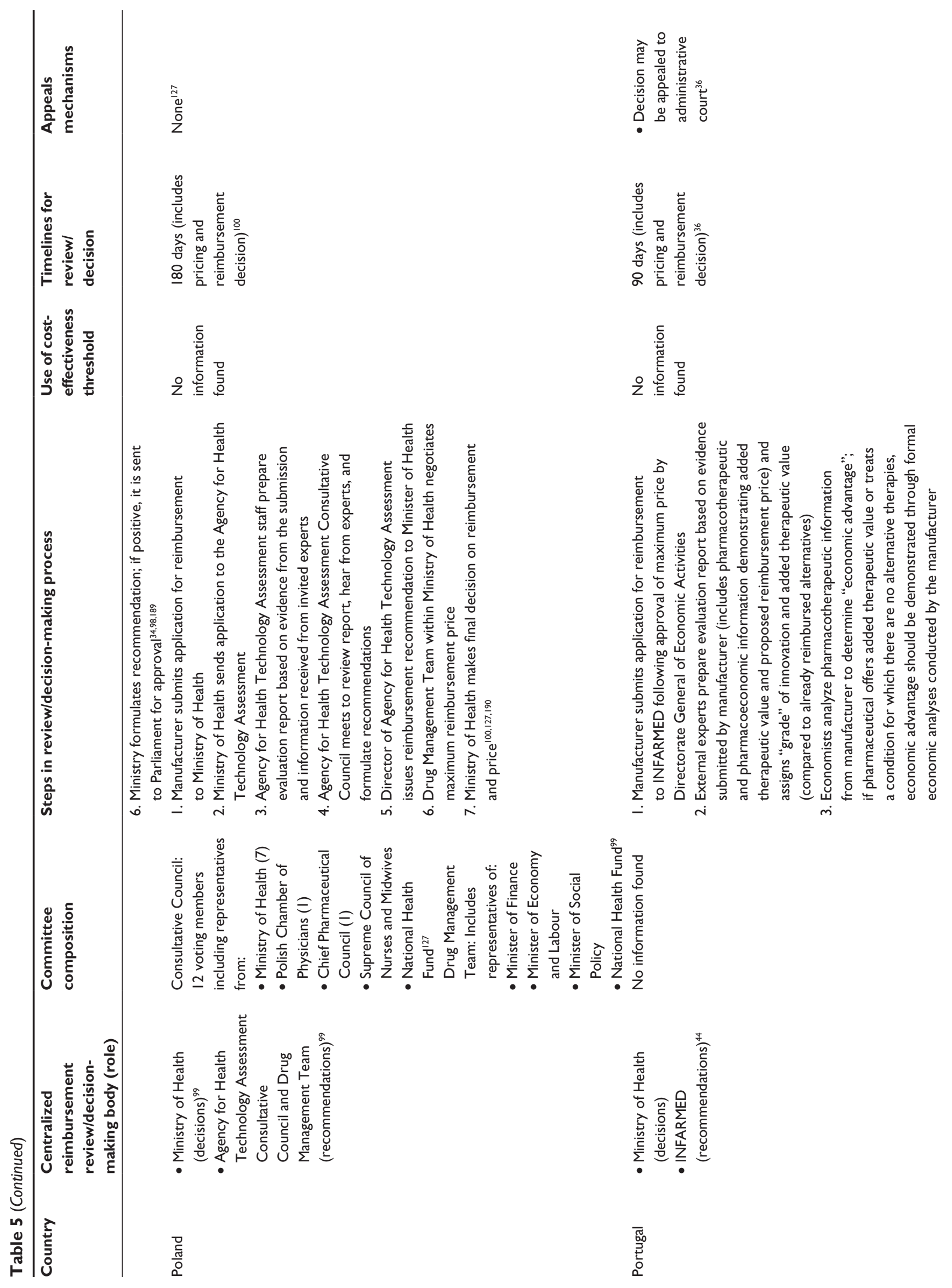



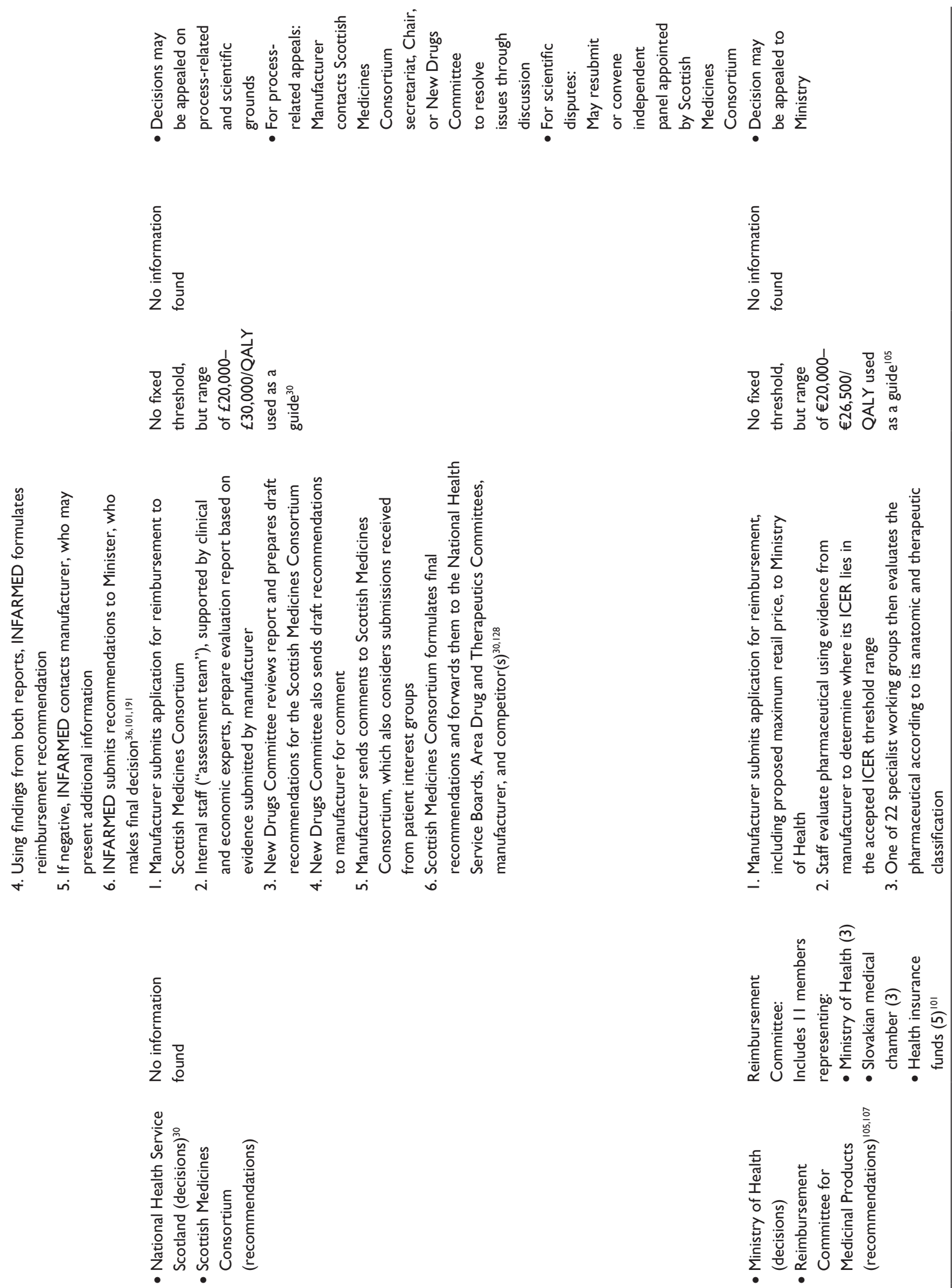

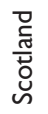

$\frac{\sqrt[n]{n}}{\frac{\pi}{20}}$ 


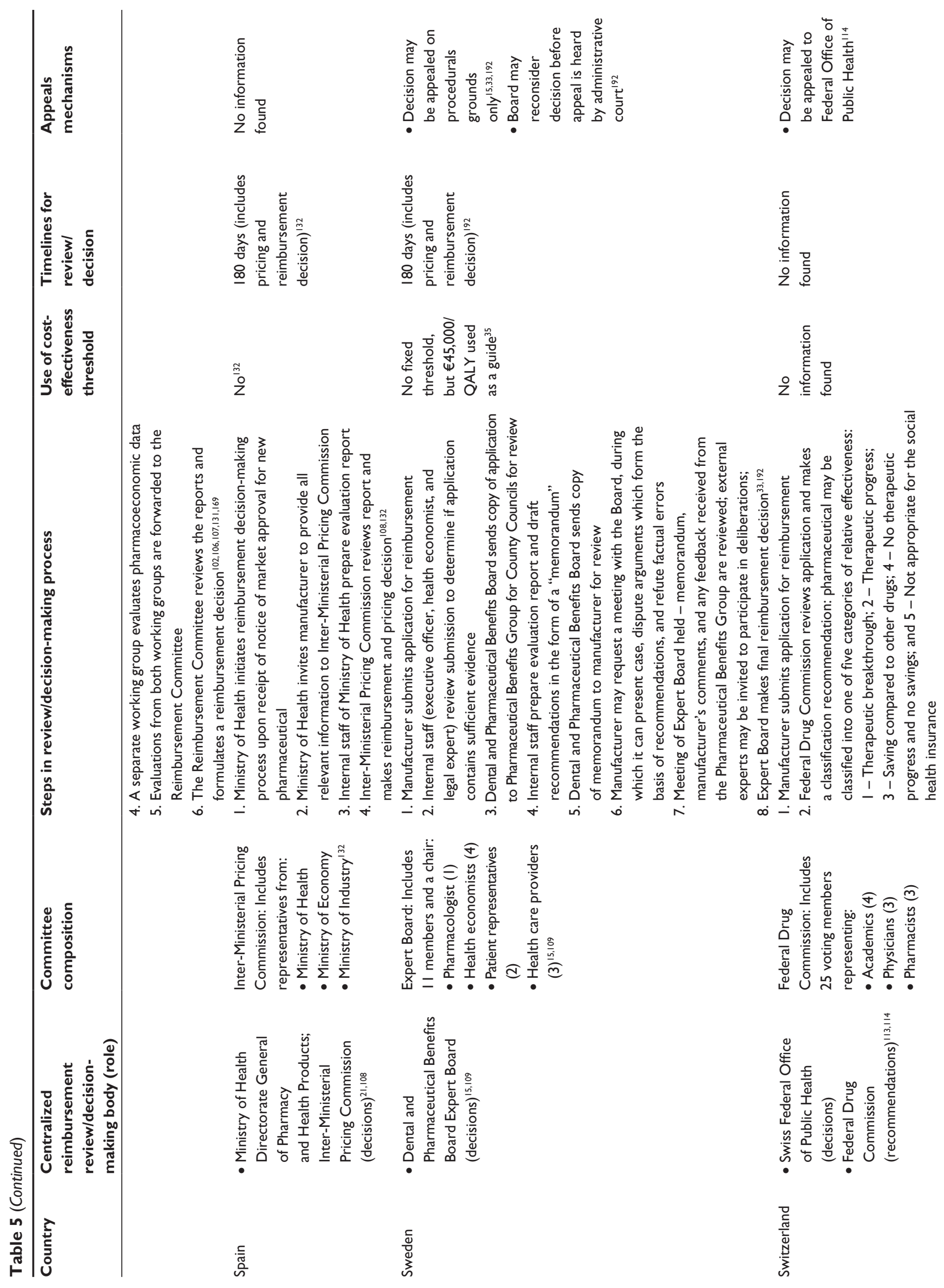



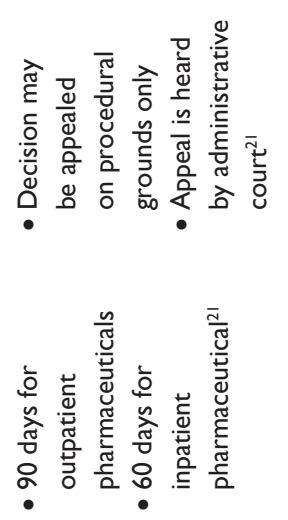

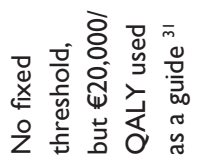
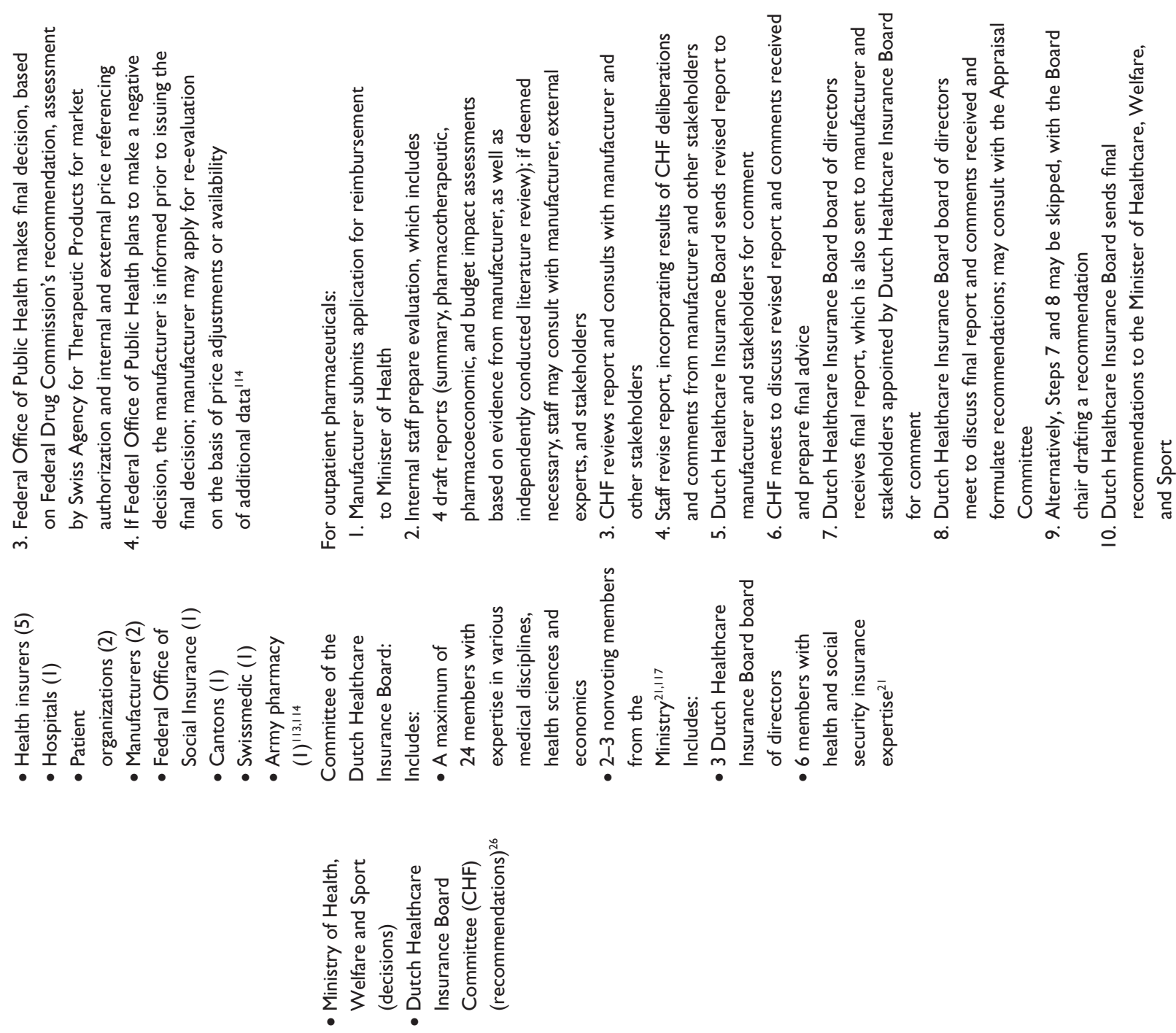

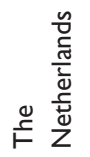




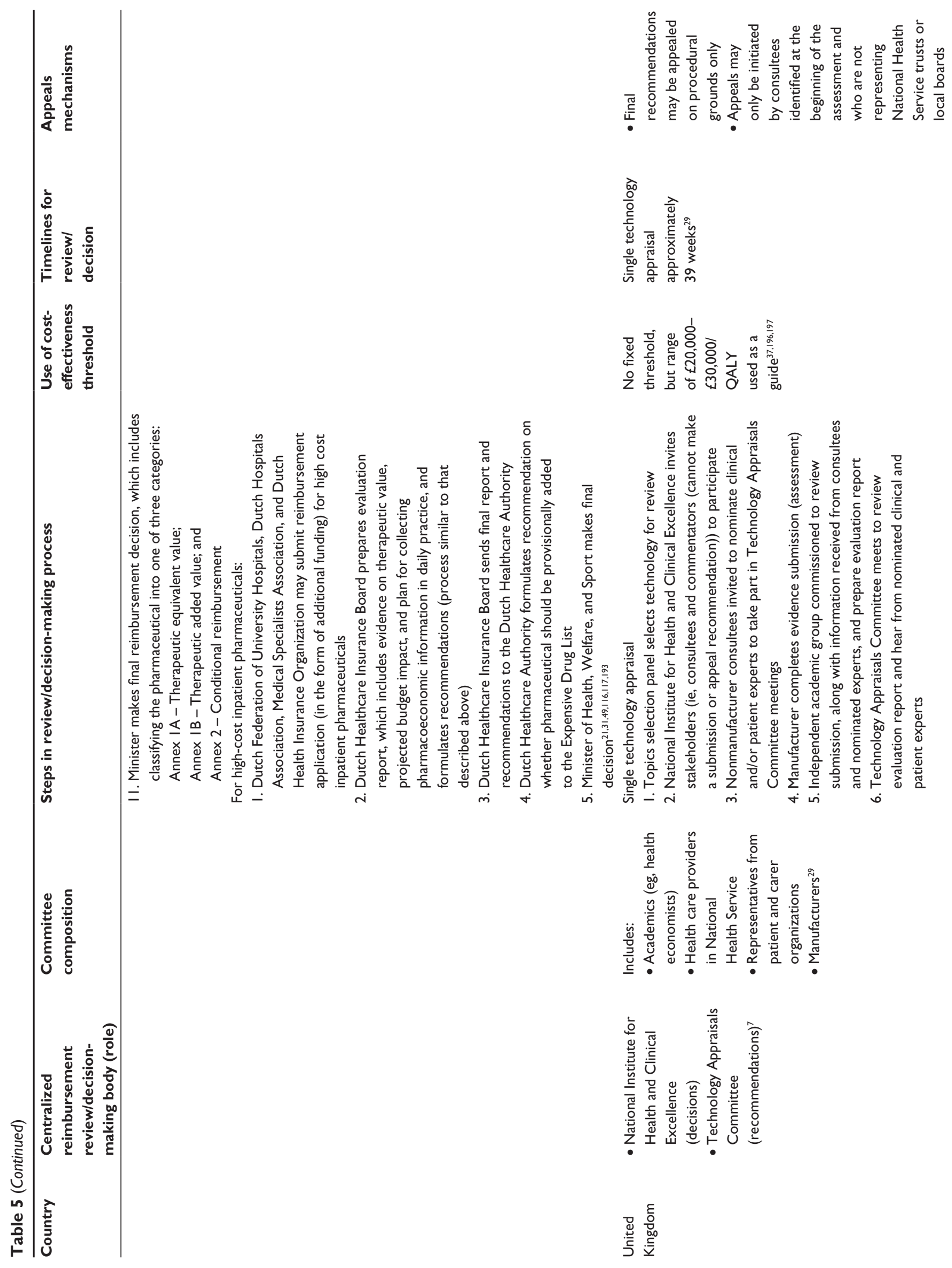



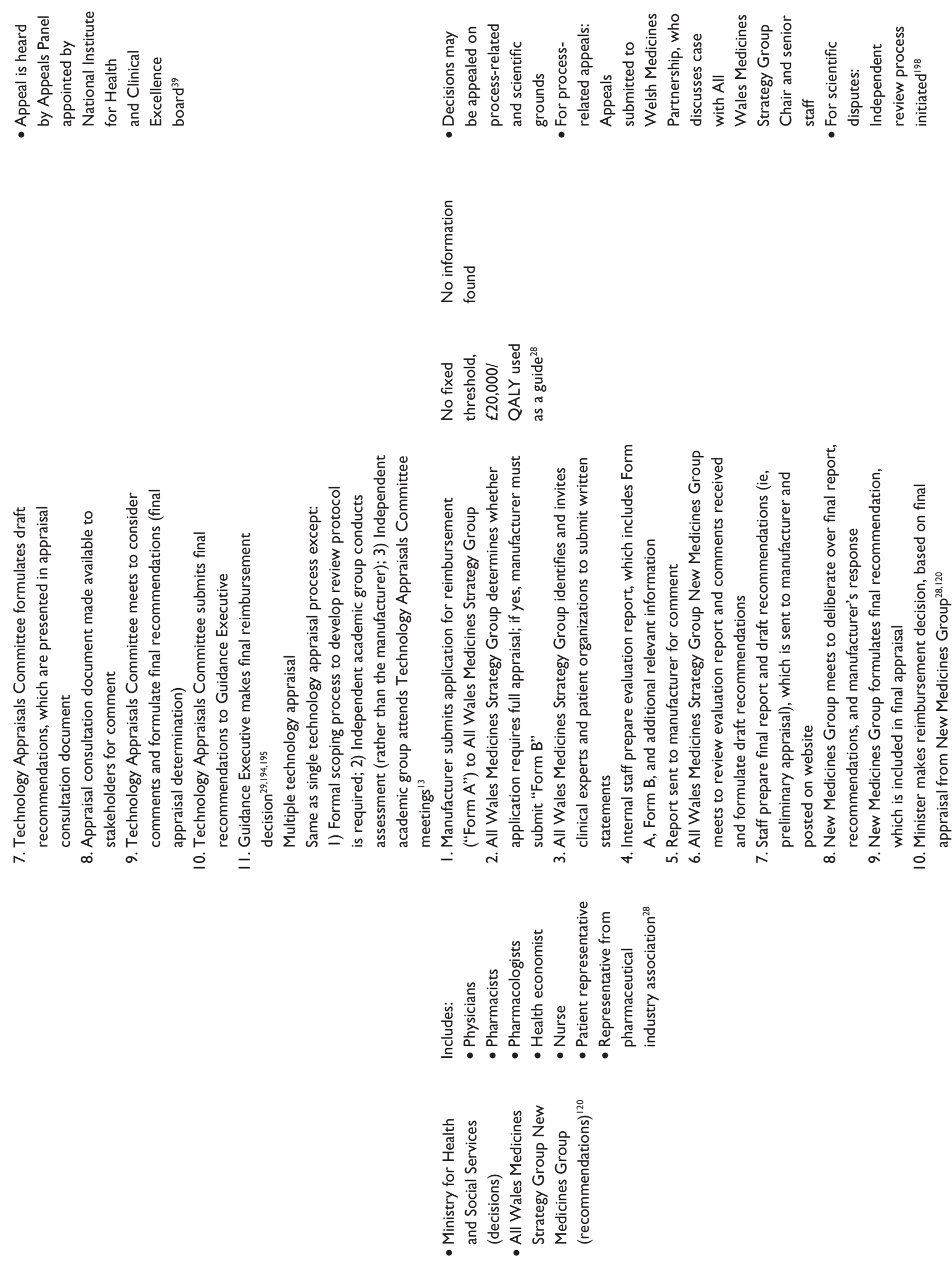

$\frac{y}{3}$ 
Table 6 Comparison of key factors considered during committee deliberations

\begin{tabular}{|c|c|c|c|c|c|}
\hline \multirow[t]{2}{*}{ Country } & \multirow{2}{*}{$\begin{array}{l}\text { Centralized } \\
\text { reimbursement } \\
\text { review/decision- } \\
\text { making body } \\
\text { (role) }\end{array}$} & \multicolumn{3}{|l|}{ Clinical need } & \multirow{2}{*}{$\begin{array}{l}\text { Clinical benefit/value* } \\
\text { Safety } \\
\text { (risk-benefit } \\
\text { ratio; harm- } \\
\text { benefit ratio) }\end{array}$} \\
\hline & & $\begin{array}{l}\text { Disease burden } \\
\text { (severity and } \\
\text { number of } \\
\text { patients) }\end{array}$ & $\begin{array}{l}\text { Availability } \\
\text { of alternatives }\end{array}$ & $\begin{array}{l}\text { Place of } \\
\text { technology in } \\
\text { care pathwayl } \\
\text { strategy }\end{array}$ & \\
\hline Austria & $\begin{array}{l}\text { - Association of Austrian } \\
\text { Social Security } \\
\text { Institutions (decisions) }{ }^{55} \\
\text { - Pharmaceutical Evaluation } \\
\text { Board (recommendations) })^{56}\end{array}$ & Yes $^{55}$ & Yes $^{58}$ & $\begin{array}{l}\text { Not } \\
\text { specified }\end{array}$ & Not specified \\
\hline Belgium & $\begin{array}{l}\text { - Ministry of Health and Social } \\
\text { Affairs (decisions) } \\
\text { - Drug Reimbursement Committee } \\
\text { (recommendations) }{ }^{9,60}\end{array}$ & Yes $^{11,17}$ & Yes $^{21}$ & $\begin{array}{l}\text { Not } \\
\text { specified }\end{array}$ & Yes $^{9}$ \\
\hline $\begin{array}{l}\text { Czech } \\
\text { Republic }\end{array}$ & $\begin{array}{l}\text { - State Institute for Drug } \\
\text { Control (decisions) }{ }^{65,176}\end{array}$ & $Y_{e s}{ }^{84}$ & $Y_{e s}{ }^{84}$ & $\begin{array}{l}\text { Not } \\
\text { specified }\end{array}$ & $Y_{e s}{ }^{84}$ \\
\hline Denmark & $\begin{array}{l}\text { - Danish Medicines Agency } \\
\text { (decisions) })^{68,69,121} \\
\text { - Reimbursement Committee } \\
\text { (recommendations) })^{68,121}\end{array}$ & $\begin{array}{l}\text { Not } \\
\text { specified }\end{array}$ & $\begin{array}{l}\text { Not } \\
\text { specified }\end{array}$ & $\begin{array}{l}\text { Not } \\
\text { specified }\end{array}$ & Yes $^{21,68}$ \\
\hline Estonia & $\begin{array}{l}\text { - Ministry of Social Affairs } \\
\text { (decisions })^{72} \\
\text { - Pharmaceuticals Committee } \\
\text { (recommendations) })^{72}\end{array}$ & $Y^{8}{ }^{84}$ & Yes $^{84}$ & $\begin{array}{l}\text { Not } \\
\text { specified }\end{array}$ & $\begin{array}{l}\text { Not } \\
\text { specified }\end{array}$ \\
\hline Finland & $\begin{array}{l}\text { - Pharmaceuticals Pricing } \\
\text { Board (decisions) })^{74,76,77} \\
\text { - Pharmaceuticals Pricing } \\
\text { Board Expert Group } \\
\text { (recommendations) }^{75}\end{array}$ & Yes $^{\mid 81}$ & Yes $^{181}$ & $\begin{array}{l}\text { Not } \\
\text { specified }\end{array}$ & $\begin{array}{l}\text { Not } \\
\text { specified }\end{array}$ \\
\hline France & $\begin{array}{l}\text { - Ministry for Health and Social } \\
\text { Security (decisions) })^{20,78} \\
\text { - French National Authority for } \\
\text { Health (recommendations) }{ }^{78}\end{array}$ & Yes $^{35}$ & Yes $^{35}$ & Yes $^{35}$ & $Y_{e s}{ }^{80}$ \\
\hline Germany & $\begin{array}{l}\text { - Federal Joint } \\
\text { Committee (decisions) })^{24} \\
\text { - Institute for Quality and } \\
\text { Efficiency in Health Care } \\
\text { (recommendations) })^{19,24}\end{array}$ & Yes $^{19}$ & Yes $^{19}$ & $\begin{array}{l}\text { Not } \\
\text { specified }\end{array}$ & Yes $^{19}$ \\
\hline Greece & $\begin{array}{l}\text { - Transparency Committee in the } \\
\text { Reimbursement and Medicinal } \\
\text { Products (makes decisions) }\end{array}$ & Yes $^{186}$ & Yes $^{186}$ & $\begin{array}{l}\text { Not } \\
\text { specified }\end{array}$ & Yes $^{186}$ \\
\hline Hungary & $\begin{array}{l}\text { - Ministers of Health and Finance } \\
\text { - National Health Insurance } \\
\text { Fund Administration } \\
\text { (recommendations) }^{88}\end{array}$ & $Y_{e s}^{186}$ & Yes $^{84}$ & $\begin{array}{l}\text { Not } \\
\text { specified }\end{array}$ & $\begin{array}{l}\text { Not } \\
\text { specified }\end{array}$ \\
\hline Ireland & $\begin{array}{l}\text { - Health Service Executive } \\
\text { (decisions) })^{9,92,147}\end{array}$ & Yes $^{125,165}$ & Yes $^{125,165}$ & $\begin{array}{l}\text { Not } \\
\text { specified }\end{array}$ & $\begin{array}{l}\text { Not } \\
\text { specified }\end{array}$ \\
\hline
\end{tabular}




\begin{tabular}{|c|c|c|c|c|c|c|}
\hline $\begin{array}{l}\text { Efficacyl } \\
\text { effectiveness }\end{array}$ & $\begin{array}{l}\text { Side } \\
\text { effects }\end{array}$ & $\begin{array}{l}\text { Acceptability } \\
\text { (tolerance, } \\
\text { convenience) }\end{array}$ & $\begin{array}{l}\text { Cost-benefit } \\
\text { ratio (cost- } \\
\text { effectiveness; } \\
\text { efficiency; "value } \\
\text { for money") } \dagger\end{array}$ & $\begin{array}{l}\text { Impact on health } \\
\text { resources/ } \\
\text { affordability } \\
\text { (budget impact) }\end{array}$ & Innovativeness & Other \\
\hline$Y_{e s}^{55}$ & $\begin{array}{l}\text { Not } \\
\text { specified }\end{array}$ & $\begin{array}{l}\text { Not } \\
\text { specified }\end{array}$ & $\begin{array}{l}\text { Yes (“pharmaco- } \\
\text { economic } \\
\text { evidence") })^{58}\end{array}$ & Yes $^{55}$ & $Y_{e s}^{50}$ & $\begin{array}{l}\text { Price in other European } \\
\text { Union countries }{ }^{58}\end{array}$ \\
\hline $\begin{array}{l}\text { Yes (across } \\
\text { patient } \\
\text { subgroups) }\end{array}$ & Yes $^{9}$ & $Y_{e s^{11,17}}$ & Yes $^{11,17}$ & $Y_{e s^{11,17}}$ & Yes $^{35}$ & $\begin{array}{l}\text { - Feasibility of } \\
\text { implementation }{ }^{11,17} \\
\text { - Market price } \\
\text { - Social needs } \\
\text {-11,17,21 }\end{array}$ \\
\hline Yes $^{84}$ & $\begin{array}{l}\text { Not } \\
\text { specified }\end{array}$ & $Y_{e s}^{66}$ & $Y_{e s}{ }^{84}$ & Yes $^{84}$ & $\begin{array}{l}\text { Not } \\
\text { specified }\end{array}$ & $\begin{array}{l}\text { - Clinical practice } \\
\text { guidelines }{ }^{138} \\
\text { - Public interest }{ }^{35}\end{array}$ \\
\hline $\begin{array}{l}\text { Yes (across } \\
\text { patient } \\
\text { subgroups) } \\
21,68\end{array}$ & $Y_{e s}^{21,68}$ & $\begin{array}{l}\text { Not } \\
\text { specified }\end{array}$ & $Y_{e s}^{21,68}$ & $\begin{array}{l}\text { Not } \\
\text { specified }\end{array}$ & $\begin{array}{l}\text { Not } \\
\text { specified }\end{array}$ & $\begin{array}{l}\text { - Reasonableness of price } \\
\text { relative to therapeutic } \\
\text { value }^{21,68}\end{array}$ \\
\hline Yes $^{84}$ & $\begin{array}{l}\text { Not } \\
\text { specified }\end{array}$ & $\begin{array}{l}\text { Not } \\
\text { specified }\end{array}$ & $Y_{e s}{ }^{84}$ & Yes $^{84}$ & $\begin{array}{l}\text { Not } \\
\text { specified }\end{array}$ & - “Cost efficiency” \\
\hline $\begin{array}{l}\text { Yes (across } \\
\text { patient } \\
\text { subgroups) }^{|8|}\end{array}$ & $\begin{array}{l}\text { Not } \\
\text { specified }\end{array}$ & $\begin{array}{l}\text { Not } \\
\text { specified }\end{array}$ & Yes $^{181}$ & Yes $^{181}$ & $\begin{array}{l}\text { Not } \\
\text { specified }\end{array}$ & $\begin{array}{l}\text { - Research and } \\
\text { development }{ }^{35} \\
\text { - Level of uncertainty in } \\
\text { supporting evidence }{ }^{181} \\
\text { - Price in other European } \\
\text { Union countries }{ }^{181} \\
\text { - Market forecast and share }{ }^{75} \\
\text { - Daily cost of treatment } \\
\text { per day }{ }^{75}\end{array}$ \\
\hline Yes $^{35}$ & Yes $^{80}$ & Yes $^{80}$ & $\begin{array}{l}\text { Not } \\
\text { specified }\end{array}$ & Yes $^{80}$ & Yes $^{35}$ & $\begin{array}{l}\text { - Public health impact } \\
\text { - Costs relative to } \\
\text { current treatment } \\
\text { 199 }\end{array}$ \\
\hline Yes $^{19}$ & $\begin{array}{l}\text { Not } \\
\text { specified }\end{array}$ & $\begin{array}{l}\text { Not } \\
\text { specified }\end{array}$ & Yes $\$ 19$ & Yes $^{113}$ & Yes $^{19}$ & \\
\hline$Y_{e s}^{186}$ & $\begin{array}{l}\text { Not } \\
\text { specified }\end{array}$ & $\begin{array}{l}\text { Not } \\
\text { specified }\end{array}$ & $\begin{array}{l}\text { Yes (“pharmaco- } \\
\text { economic } \\
\text { effectiveness") }\end{array}$ & $\begin{array}{l}\text { Not } \\
\text { specified }\end{array}$ & $\begin{array}{l}\text { Not } \\
\text { specified }\end{array}$ & $\begin{array}{l}\text { - Daily cost of } \\
\text { treatment }{ }^{186} \\
\text { - Reimbursement status } \\
\text { in other European } \\
\text { Union countries }\end{array}$ \\
\hline Yes $^{84}$ & $\begin{array}{l}\text { Not } \\
\text { specified }\end{array}$ & $\begin{array}{l}\text { Not } \\
\text { specified }\end{array}$ & Yes $^{186}$ & Yes $^{84}$ & $\begin{array}{l}\text { Not } \\
\text { specified }\end{array}$ & - Equity ${ }^{26}$ \\
\hline Yes $^{125,165}$ & $\begin{array}{l}\text { Not } \\
\text { specified }\end{array}$ & $\begin{array}{l}\text { Not } \\
\text { specified }\end{array}$ & Yes $^{125,165}$ & Yes $^{125,165}$ & Yes $^{125,165}$ & $\begin{array}{l}\text { - Level of uncertainty in } \\
\text { supporting evidence }{ }^{125} \\
\text { - Wider societal costs } \\
\text { and benefits } \\
{ }^{165}\end{array}$ \\
\hline
\end{tabular}


Table 6 (Continued)

\begin{tabular}{|c|c|c|c|c|c|}
\hline \multirow[t]{2}{*}{ Country } & \multirow[b]{2}{*}{$\begin{array}{l}\text { Centralized } \\
\text { reimbursement } \\
\text { review/decision- } \\
\text { making body } \\
\text { (role) }\end{array}$} & \multicolumn{3}{|l|}{ Clinical need } & \multirow{2}{*}{$\begin{array}{l}\text { Clinical benefit/value* } \\
\text { Safety } \\
\text { (risk-benefit } \\
\text { ratio; harm- } \\
\text { benefit ratio) }\end{array}$} \\
\hline & & $\begin{array}{l}\text { Disease burden } \\
\text { (severity and } \\
\text { number of } \\
\text { patients) }\end{array}$ & $\begin{array}{l}\text { Availability } \\
\text { of alternatives }\end{array}$ & $\begin{array}{l}\text { Place of } \\
\text { technology in } \\
\text { care pathwayl } \\
\text { strategy }\end{array}$ & \\
\hline Italy & $\begin{array}{l}\text { - Italian Medicines Agency Technical } \\
\text { Scientific Committee (decisions) } \\
\text { - Italian Medicines Agency Pricing } \\
\text { and Reimbursement Committee } \\
\text { (recommendations) })^{95}\end{array}$ & $\mathrm{Yes}^{27}$ & $\mathrm{Yes}^{27}$ & $\begin{array}{l}\text { Not } \\
\text { specified }\end{array}$ & Yes $^{96}$ \\
\hline Norway & 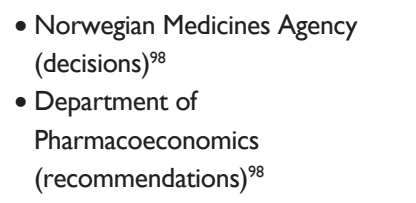 & Yes $^{34}$ & $\begin{array}{l}\text { Not } \\
\text { specified }\end{array}$ & $\begin{array}{l}\text { Not } \\
\text { specified }\end{array}$ & Yes $^{149}$ \\
\hline Poland & - Ministry of Health (decisions) ${ }^{99}$ & $Y_{e s}{ }^{84}$ & $\begin{array}{l}\text { Not } \\
\text { specified }\end{array}$ & $\begin{array}{l}\text { Not } \\
\text { specified }\end{array}$ & $Y_{e s}{ }^{84}$ \\
\hline Portugal & $\begin{array}{l}\text { - Ministry of Health (decisions) } \\
\text { - INFARMED } \\
\text { (recommendations) })^{36,44}\end{array}$ & $\mathrm{Yes}^{36}$ & $\mathrm{Yes}^{36}$ & $\begin{array}{l}\text { Not } \\
\text { specified }\end{array}$ & $\mathrm{Yes}^{36}$ \\
\hline Scotland & $\begin{array}{l}\text { - National Health Service } \\
\text { Scotland (decisions) })^{30} \\
\text { - Scottish Medicines Consortium } \\
\text { (recommendations) }\end{array}$ & Yes $^{104}$ & $Y_{e s}^{30}$ & $\begin{array}{l}\text { Not } \\
\text { specified }\end{array}$ & Yes $^{104}$ \\
\hline Slovakia & $\begin{array}{l}\text { - Ministry of Health (decisions) } \\
\text { - Reimbursement Committee } \\
\text { for Medicinal Products } \\
\text { (recommendations) }^{105,107,169}\end{array}$ & Yes $^{106}$ & $Y_{e s}^{84}$ & $\begin{array}{l}\text { Not } \\
\text { specified }\end{array}$ & Yes $^{106}$ \\
\hline Spain & $\begin{array}{l}\text { - Ministry of Health Directorate } \\
\text { General of Pharmacy and Health } \\
\text { Products; Inter-Ministerial Pricing } \\
\text { Commission (decisions) }\end{array}$ & Yes $^{132}$ & Yes $^{132}$ & $\begin{array}{l}\text { Not } \\
\text { specified }\end{array}$ & Yes $^{10}$ \\
\hline Sweden & $\begin{array}{l}\text { - Dental and Pharmaceutical } \\
\text { Benefits Board Expert Board } \\
\text { (decisions) }^{15,109,110}\end{array}$ & $Y_{e s}^{21}$ & Yes $^{109}$ & $\begin{array}{l}\text { Not } \\
\text { specified }\end{array}$ & $Y_{e s}^{21}$ \\
\hline Switzerland & $\begin{array}{l}\text { - Swiss Federal Office of Public } \\
\text { Health (decisions) } \\
\text { - Federal Drug Commission } \\
\text { (recommendations) }{ }^{113,114}\end{array}$ & $\begin{array}{l}\text { Not } \\
\text { specified }\end{array}$ & $\begin{array}{l}\text { Not } \\
\text { specified }\end{array}$ & $\begin{array}{l}\text { Not } \\
\text { specified }\end{array}$ & Not specified \\
\hline
\end{tabular}




\begin{tabular}{|c|c|c|c|c|c|c|}
\hline $\begin{array}{l}\text { Efficacyl } \\
\text { effectiveness }\end{array}$ & $\begin{array}{l}\text { Side } \\
\text { effects }\end{array}$ & $\begin{array}{l}\text { Acceptability } \\
\text { (tolerance, } \\
\text { convenience) }\end{array}$ & $\begin{array}{l}\text { Cost-benefit } \\
\text { ratio (cost- } \\
\text { effectiveness; } \\
\text { efficiency; "value } \\
\text { for money") }{ }^{\dagger}\end{array}$ & $\begin{array}{l}\text { Impact on health } \\
\text { resources/ } \\
\text { affordability } \\
\text { (budget impact) }\end{array}$ & Innovativeness & Other \\
\hline $\begin{array}{l}\text { Yes (across } \\
\text { patient } \\
\text { subgroups) }{ }^{27}\end{array}$ & $\begin{array}{l}\text { Not } \\
\text { specified }\end{array}$ & $\mathrm{Yes}^{27}$ & Yes $^{27}$ & Yes $^{27}$ & $Y_{e s}{ }^{20}$ & $\begin{array}{l}\text { - Daily cost of } \\
\text { treatment }{ }^{27} \\
\text { - "Special medical } \\
\text { needs"96 } \\
\text { - Price in other European } \\
\text { Union countries }{ }^{200} \\
\text { - Market forecast and share }{ }^{96}\end{array}$ \\
\hline $\begin{array}{l}\text { Yes (across } \\
\text { patient } \\
\text { subgroups) })^{34}\end{array}$ & $\begin{array}{l}\text { Not } \\
\text { specified }\end{array}$ & $\begin{array}{l}\text { Not } \\
\text { specified }\end{array}$ & $Y_{e s}^{34}$ & Yes $^{34}$ & $\begin{array}{l}\text { Not } \\
\text { specified }\end{array}$ & $\begin{array}{l}\text { - Equity } 35 \\
\text { - "Solidarity"34 } \\
\text { - "Rationality"34 }\end{array}$ \\
\hline Yes $^{84}$ & $\begin{array}{l}\text { Not } \\
\text { specified }\end{array}$ & $\begin{array}{l}\text { Not } \\
\text { specified }\end{array}$ & $Y^{8}{ }^{84}$ & Yes $^{84}$ & $\begin{array}{l}\text { Not } \\
\text { specified }\end{array}$ & \\
\hline Yes $^{36}$ & $\begin{array}{l}\text { Not } \\
\text { specified }\end{array}$ & $\begin{array}{l}\text { Not } \\
\text { specified }\end{array}$ & Yes $^{36}$ & $\begin{array}{l}\text { Not } \\
\text { specified }\end{array}$ & $\begin{array}{l}\text { Not } \\
\text { specified }\end{array}$ & $\begin{array}{l}\text { - Equity }{ }^{36} \\
\text { - "Universality"36 } \\
\text { - "Accessibility"36 }\end{array}$ \\
\hline$Y_{e s}{ }^{104}$ & $\begin{array}{l}\text { Not } \\
\text { specified }\end{array}$ & $\begin{array}{l}\text { Not } \\
\text { specified }\end{array}$ & $Y_{e s}{ }^{104}$ & Yes $^{104}$ & Yes $^{30}$ & $\begin{array}{l}\text { - Whether pharmaceutical } \\
\text { reverses rather than } \\
\text { stabilizes condition } \\
\text { or bridges a gap to } \\
\text { curative therapy } y^{104} \\
\text { - Level of uncertainty in } \\
\text { supporting evidence } \\
\text { - Wider societal costs } \\
\text { and benefits }{ }^{30}\end{array}$ \\
\hline Yes $^{106}$ & Yes $^{106}$ & Yes $^{106}$ & $Y_{e s}^{84,105}$ & $Y_{e s}{ }^{84,106}$ & $\begin{array}{l}\text { Not } \\
\text { specified }\end{array}$ & $\begin{array}{l}\text { Price of other } \\
\text { pharmaceuticals within } \\
\text { reference category }\end{array}$ \\
\hline $\begin{array}{l}\text { Yes (across } \\
\text { patient } \\
\text { subgroups) }\end{array}$ & $\begin{array}{l}\text { Not } \\
\text { specified }\end{array}$ & $\begin{array}{l}\text { Not } \\
\text { specified }\end{array}$ & Not specified & Yes $^{132}$ & Yes $^{108}$ & $\begin{array}{l}\text { - "Social utility"|32 } \\
\text { - Rationalization of } \\
\text { public expenditures } \\
\text { on pharmaceuticals }{ }^{132} \\
\text { - Specific needs of certain } \\
\text { groups of people }{ }^{132} \\
\text { - Research and } \\
\text { development } \\
\text { - Price in other European } \\
\text { Union countries } \\
\text { - Market forecast }{ }^{132}\end{array}$ \\
\hline $\begin{array}{l}\text { Yes (across } \\
\text { patient } \\
\text { subgroups) } \\
15,21\end{array}$ & $\begin{array}{l}\text { Not } \\
\text { specified }\end{array}$ & $\begin{array}{l}\text { Not } \\
\text { specified }\end{array}$ & $Y_{e s}^{21}$ & $\mathrm{No}^{21}$ & $\begin{array}{l}\text { Not } \\
\text { specified }\end{array}$ & $\begin{array}{l}\text { - Equity } 35 \\
\text { "Reasonableness of } \\
\text { cost from medical, } \\
\text { humanitarian, and } \\
\text { socio-economic } \\
\text { perspective" } \\
\text { - Solidarity" }\end{array}$ \\
\hline$Y_{e s}^{108}$ & $\begin{array}{l}\text { Not } \\
\text { specified }\end{array}$ & $\begin{array}{l}\text { Not } \\
\text { specified }\end{array}$ & $\begin{array}{l}\text { Yes ("value for } \\
\text { money") }\end{array}$ & Not specified & Yes $^{108}$ & $\begin{array}{l}\text { - Research and } \\
\text { development }{ }^{109}\end{array}$ \\
\hline
\end{tabular}


Table 6 (Continued)

\begin{tabular}{|c|c|c|c|c|c|}
\hline \multirow[t]{2}{*}{ Country } & \multirow{2}{*}{$\begin{array}{l}\text { Centralized } \\
\text { reimbursement } \\
\text { review/decision- } \\
\text { making body } \\
\text { (role) }\end{array}$} & \multicolumn{3}{|l|}{ Clinical need } & \multirow{2}{*}{$\begin{array}{l}\text { Clinical benefit/value* } \\
\text { Safety } \\
\text { (risk-benefit } \\
\text { ratio; harm- } \\
\text { benefit ratio) }\end{array}$} \\
\hline & & $\begin{array}{l}\text { Disease burden } \\
\text { (severity and } \\
\text { number of } \\
\text { patients) }\end{array}$ & $\begin{array}{l}\text { Availability } \\
\text { of alternatives }\end{array}$ & $\begin{array}{l}\text { Place of } \\
\text { technology in } \\
\text { care pathwayl } \\
\text { strategy }\end{array}$ & \\
\hline The Netherlands & $\begin{array}{l}\text { Ministry of Health, } \\
\text { Welfare and Sport (decisions) } \\
\text { Dutch Healthcare Insurance } \\
\text { Board Committee of the } \\
\text { Dutch Healthcare Insurance } \\
\text { Board (recommendations) }\end{array}$ & Yes $^{35}$ & Yes $^{21}$ & $\begin{array}{l}\text { Not } \\
\text { specified }\end{array}$ & $Y_{e s}^{35}$ \\
\hline United Kingdom & $\begin{array}{l}\text { - National Institute for Health and } \\
\text { Clinical Excellence (decisions) } \\
\text { - Technology Appraisals } \\
\text { Committee (recommendations) }{ }^{7}\end{array}$ & $\mathrm{Yes}^{202}$ & $\mathrm{Yes}^{202}$ & $\mathrm{Yes}^{202}$ & $Y_{e s}^{202}$ \\
\hline Wales & $\begin{array}{l}\text { - Ministry for Health and Social } \\
\text { Services (decisions) } \\
\text { - All Wales Medicines Strategy } \\
\text { Group (recommendations) }\end{array}$ & $\mathrm{Yes}^{28}$ & $\begin{array}{l}\text { Not } \\
\text { specified }\end{array}$ & $\begin{array}{l}\text { Not } \\
\text { specified }\end{array}$ & $\begin{array}{l}\text { Not } \\
\text { specified }\end{array}$ \\
\hline
\end{tabular}

they include at least safety (risk-benefit ratio) and efficacy/ effectiveness, on the basis of which an overall estimate of the ratio of the benefits to harms of a candidate technology is estimated (Table 6). While a further goal shared by most review committees is to formulate an opinion on whether the candidate technology represents "value for money" or an efficient use of resources, their approach to accomplishing this differs. Approximately one-third are guided by, but not compelled to adhere to, a predefined incremental costeffectiveness threshold or threshold range. ${ }^{28,29}$ Typically, if the incremental cost-effectiveness for a candidate technology lies below the threshold, it is deemed cost-effective or good value for money. If it lies above the threshold, additional factors are taken into account when judging acceptability (eg, uncer- tainties in estimates of outcomes, the severity of condition, and wider societal benefits). ${ }^{30,31}$ Across systems whose committees do not refer to an incremental cost-effectiveness threshold, approaches to operationalizing "value or money" appear vague, with information largely limited to statements such as "reasonableness of cost relative to therapeutic value" (Table 6). ${ }^{32}$ Similarly, although all but one of the systems (Sweden ${ }^{21}$ ) list "affordability" or "impact of the candidate technology on health system resources" among factors/criteria considered by their respective review committees, no information describing processes for deciding whether or not a technology is affordable could be found.

Equity or ethical implications comprise decision-making factors/criteria (explicitly or implicitly) in one-third of 


\begin{tabular}{|c|c|c|c|c|c|c|}
\hline $\begin{array}{l}\text { Efficacyl } \\
\text { effectiveness }\end{array}$ & $\begin{array}{l}\text { Side } \\
\text { effects }\end{array}$ & $\begin{array}{l}\text { Acceptability } \\
\text { (tolerance, } \\
\text { convenience) }\end{array}$ & $\begin{array}{l}\text { Cost-benefit } \\
\text { ratio (cost- } \\
\text { effectiveness; } \\
\text { efficiency; "value } \\
\text { for money") }\end{array}$ & $\begin{array}{l}\text { Impact on health } \\
\text { resources/ } \\
\text { affordability } \\
\text { (budget impact) }\end{array}$ & Innovativeness & Other \\
\hline$Y_{e s}^{35,117}$ & Yes $^{35}$ & $Y_{e s}^{35}$ & $Y_{e s}^{35,117}$ & Yes $^{* 21,201}$ & $Y_{e s}^{35}$ & $\begin{array}{l}\text { - Rarity } \\
\text { - Feasibility of } \\
\text { implementation }{ }^{117} \\
\text { - Accessibility } \\
\text { - Level of uncertainty in } \\
\text { supporting evidence }{ }^{115} \\
\text { - Individual versus } \\
\text { collective } \\
\text { responsibility }{ }^{201} \\
\text { - Public health impact }\end{array}$ \\
\hline $\begin{array}{l}\text { Yes (across } \\
\text { patient } \\
\text { subgroups) }\end{array}$ & $\begin{array}{l}\text { Not } \\
\text { specified }\end{array}$ & $\begin{array}{l}\text { Not } \\
\text { specified }\end{array}$ & $Y_{e s}^{202}$ & Not specified & $Y_{e s}^{35,197}$ & $\begin{array}{l}\text { - Level of uncertainty in } \\
\text { supporting evidence }{ }^{196} \\
\text { - Whether technology } \\
\text { represents life-extending, } \\
\text { end of life treatment }{ }^{37} \\
\text { - Wider societal costs and } \\
\text { benefits } \\
\text { - Public health impact } \\
\text { - Alignment with broad } \\
\text { government priorities }{ }^{202} \\
\text { - ICERs of already funded } \\
\text { programmes } \\
13,157\end{array}$ \\
\hline $\begin{array}{l}\text { Yes (across } \\
\text { patient } \\
\text { subgroups) }\end{array}$ & $\begin{array}{l}\text { Not } \\
\text { specified }\end{array}$ & $\begin{array}{l}\text { Not } \\
\text { specified }\end{array}$ & $Y_{e s}^{28}$ & Yes $^{174}$ & $Y_{e s}^{28}$ & $\begin{array}{l}\text { - Level of uncertainty in } \\
\text { supporting evidence }{ }^{174} \\
\text { - Wider societal costs and } \\
\text { benefits } \\
\text { - Alignment with broad } \\
\text { government priorities }{ }^{28} \\
\text { - ICERs of funded } \\
\text { programmes }^{28}\end{array}$ \\
\hline
\end{tabular}

Notes: *In a well-defined population; ${ }^{\dagger}$ price proportionate to effect; ${ }^{\S}$ cost efficiency takes into account costs of treatment per patient, as well as costs of compensatory allowance due to lost income and costs of restoring patients' capacity to work; *efficiency of resource use within a single therapeutic area relative to existing interventions; $¥$ not a formal criterion.

systems. For example, Sweden's Dental and Pharmaceutical Benefits Board stipulates two principles that decisions must reflect, ie, the "need and solidarity principle" (patients in the greatest need or "worse off" must be given priority) and the "human value principle" (sociodemographic characteristics of patient populations cannot influence decisions). ${ }^{21,33}$ Along with "solidarity," the Norwegian Medicines Agency explicitly takes into account "equity," as do review committees in Hungary and Poland. ${ }^{26,34-36}$ However, the way in which this is accomplished during deliberations is not clear. Committees using an incremental cost-effectiveness threshold to guide decisions implicitly incorporate equity by virtue of the assumptions underpinning the incremental cost-effectiveness calculation (ie, each quality-adjusted life-year [QALY] carries the same weight, regardless of the characteristics of the patients receiving it (eg, age, gender, social status, income). Consideration of additional, often competing ethical principles by these committees is operationalized through "exception" conditions under which the normal "efficiency" expectations do not need to be met (eg, "last chance" therapies, orphan technologies, life-extending, end-of-life treatments). ${ }^{37}$ Under such conditions, not all QALYs are deemed equal. Rather, a form of "solidarity" premium is applied, where, for example, QALYs gained in the later stages of disease are given greater weight. While there is little disagreement over the importance of instituting "exception" conditions as a means of ensuring that reimbursement decisions embody the broader values of the population, 
Table 7 Comparison of conditional reimbursement policy options for managing decision uncertainties

\begin{tabular}{|c|c|c|c|}
\hline \multirow[t]{2}{*}{ Country } & \multirow{2}{*}{$\begin{array}{l}\text { Centralized reimbursement } \\
\text { review/decision-making body } \\
\text { (role) }\end{array}$} & \multicolumn{2}{|c|}{ Policy options for addressing decision-making uncertainties } \\
\hline & & Reassessment & $\begin{array}{l}\text { Value-based pricing/ } \\
\text { reimbursement }\end{array}$ \\
\hline Austria & 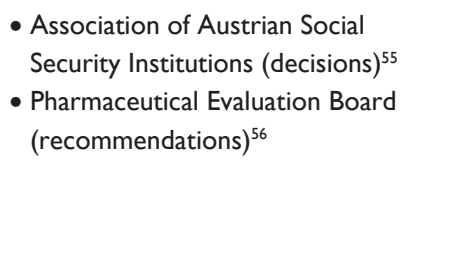 & $\begin{array}{l}\text { - Yes } \\
\text { - Association of Austrian Social Security } \\
\text { Institutions may remove pharmaceutical } \\
\text { from benefit list in the wake of new clinical } \\
\text { or economic evidence } \\
\text { - Manufacturer may suggest delisting } \\
\text { pharmaceutical }^{21}\end{array}$ & $\mathrm{No}^{56}$ \\
\hline Belgium & $\begin{array}{l}\text { - Minister of Social Affairs (decisions) } \\
\text { - Drug Reimbursement Committee } \\
\text { (recommendations) }{ }^{9}\end{array}$ & $\begin{array}{l}\text { - Yes - automatic reassessment } \\
\text { of pharmaceuticals offering added } \\
\text { therapeutic value } 1.5 \text { to } 3 \text { years after } \\
\text { inclusion on benefit list } \\
\text { - Minister of Social Affairs or manufacturer } \\
\text { may suggest delisting a pharmaceutical }{ }^{41,49}\end{array}$ & No information found \\
\hline $\begin{array}{l}\text { Czech } \\
\text { Republic }\end{array}$ & $\begin{array}{l}\text { - State Institute for Drug Control } \\
{\text { (decisions) })^{65}}\end{array}$ & $\begin{array}{l}\text { - Yes - for "highly innovative" pharmaceuticals } \\
\text { without evidence of effectiveness and } \\
\text { "efficiency" } \\
\text { - Granted provisional reimbursement } \\
\text { for I year, after which pharmaceutical } \\
\text { is reassessed" }\end{array}$ & $\begin{array}{l}\text { Manufacturer may request a } \\
\text { surcharge of up to } 30 \% \text { over } \\
\text { the basic reimbursement } \\
\text { level if evidence } \\
\text { suggests pharmaceutical } \\
\text { demonstrates "superior" } \\
\text { therapeutic benefits" }\end{array}$ \\
\hline Denmark & $\begin{array}{l}\text { - Danish Medicines Agency } \\
\text { (decisions })^{68,69,121} \\
\text { - Reimbursement Committee } \\
\text { (recommendations) })^{68,121}\end{array}$ & $\begin{array}{l}\text { - Pharmaceuticals reassessed as part of } \\
\text { therapeutic class reviews every } 5 \text { years } \\
\text { - Pharmaceutical may be scheduled for } \\
\text { a separate reassessment when initial } \\
\text { reimbursement decision is made } \\
\text { if Reimbursement Committee considers } \\
\text { it necessary to collect additional } \\
\text { information about the use of the } \\
\text { pharmaceutical in clinical practice before } \\
\text { making a definitive decision }{ }^{50}\end{array}$ & No information found \\
\hline Estonia & $\begin{array}{l}\text { - Ministry of Social Affairs } \\
\text { (decisions })^{72} \\
\text { - Pharmaceuticals Committee } \\
\text { (recommendations) })^{72}\end{array}$ & No information found & No information found \\
\hline Finland & $\begin{array}{l}\text { - Pharmaceuticals Pricing Board } \\
(\text { decisions) })^{73,74,76} \\
\text { - Pharmaceuticals Pricing Board } \\
\text { Expert Group (recommendations) }{ }^{75}\end{array}$ & $\begin{array}{l}\text { - Yes - for all pharmaceuticals } \\
\text { - Automatic reassessment every } 3 \text { to } 5 \text { years } \\
\text { after inclusion on benefit list }{ }^{182,203}\end{array}$ & No information found \\
\hline France & $\begin{array}{l}\text { - Ministry for Health and Social } \\
\text { Security (decisions) })^{20,78} \\
\text { - French National Authority } \\
\text { for Health (recommendations) }{ }^{78}\end{array}$ & $\begin{array}{l}\text { For pharmaceuticals } \\
\text { - Yes - for all pharmaceuticals } \\
\text { - Automatic reassessment every } 5 \text { years after } \\
\text { inclusion on benefit list }{ }^{20} \\
\text { For medical devices } \\
\text { - Yes - for devices } \\
\text { - Automatic reassessment within } 5 \text { years of } \\
\text { inclusion on benefit list }{ }^{20,162}\end{array}$ & No information found \\
\hline
\end{tabular}


Reimbursement as part

of a formal study

No information found

No information found

No information found

No information found

No information found

No information found

- May provide provisional coverage for a set period during which "real-world" effectiveness and/or economic implications must be assessed through a study:

- To be carried out:

I) By skilled teams in a limited number of selected centers

2) Under well-defined conditions of use

3) Using a protocol approved by French
Risk-sharing schemes/ payment by results

No information found

Other

No information found

Financially or clinically based:

- For pharmaceuticals offering added therapeutic value for which the Drug

Reimbursement Committee

formulated a negative reimbursement recommendation ${ }^{49}$

Financially based:

- Price-volume agreements - "Provision Fund" established - Advances paid by manufacturers are used to cover $75 \%$ of overrun ${ }^{41}$

No information found

Clinically based:

- Example: "No cure no pay" scheme for valsartan for high blood pressure

- Individual level schemes

- Patient may apply for reimbursement on an individual basis, which requires evidence of treatment effect for continued reimbursement ${ }^{46}$

- Typically for patients who have exhausted all other options

- Period of reimbursement varies ${ }^{68}$

Financially based:

- For all new pharmaceuticals price-volume agreements mandatory for I year following reimbursement decision $^{41}$

No information found

For pharmaceuticals

Financially based:

- Price-volume agreements

- Manufacturer must "pay back" the cost of sales exceeding those forecasted for the first 4 years ${ }^{23,43}$

- Pharmaceuticals exempt from such schemes for various periods depending on their "improvement in medical benefit"

No information found
- Creation of Special Solidarity Fund

- Grants, on an individual basis, reimbursement of pharmaceuticals for rare diseases or rare indications unavailable in Belgium

- Only granted if patient meets certain criteria and has exhausted all other treatment options

- Must be prescribed by relevant specialist

- Reimbursement decisions made by College of Medical Doctors Directors ${ }^{62}$

No information found

No information found

No information found

For pharmaceuticals for serious or rare diseases

- May be granted temporary access in a hospital setting for I year ${ }^{162}$

For "innovative" medical devices

- May establish "innovation point of contact" and an internal multidisciplinary network ${ }^{162}$

(Continued) 
Table 7 (Continued)

\begin{tabular}{llll}
\hline Country & $\begin{array}{l}\text { Centralized reimbursement } \\
\text { review/decision-making body } \\
\text { (role) }\end{array}$ & Policy options for addressing decision-making uncertainties \\
\cline { 2 - 3 } & Reassessment & $\begin{array}{l}\text { Value-based pricing/ } \\
\text { reimbursement }\end{array}$
\end{tabular}
(role)

Greece

Hungary

Ireland

Italy
- Transparency Committee in the Reimbursement and Medicinal Products (makes decisions) ${ }^{85}$

- Ministers of Health and Finance

- National Health Insurance

Fund Administration

(recommendations) $^{88,89}$
No information found

No information found

No information found

No automatic/routine reassessment, with the exception of pharmaceuticals reimbursed under condition that additional studies would be conducted ${ }^{25}$
No information found

No information found

No information found

No information found Scientific Committee (decisions) ${ }^{94}$ - Italian Medicines Agency Pricing and Reimbursement Committee (recommendations) ${ }^{95}$

- Products Committee of Corporate Pharmaceuticals Unit of Health Service Executive (decisions) ${ }^{91,92}$ 


\begin{tabular}{l}
$\begin{array}{l}\text { Reimbursement as part } \\
\text { of a formal study }\end{array}$ \\
\hline National Authority for Health \\
Transparency Committee \\
- Applies to pharmaceuticals that: \\
I) Target a large population; \\
2) May be prescribed outside their \\
labeled indications; or \\
3) May have a significant impact on health \\
care organizations ${ }^{16,20}$ \\
- Also applies to medical devices - \\
French National Authority for Health \\
specifies study protocol ${ }^{20}$ \\
For medical devices and procedures \\
- May provide provisional coverage for \\
a set period during which \\
"real-world" effectiveness \\
and/or economic implications must \\
be assessed through a study ${ }^{204}$
\end{tabular}

No information found

No information found

No information found

For pharmaceuticals classified as "potentially innovative"

- May require manufacturer to conduct additional studies within 3 years

- Pharmaceuticals for patients enrolled in the studies must be covered by the manufacturer ${ }^{25}$

- Have established ongoing registries to monitor prescribing and assess "therapeutic value" in practice (real-world settings) in order to inform future management and reimbursed pricing decisions (eg, cetuximab, lenalidomide, ibritumomab, tiuxetan, palifermin, temporfin, and trastuzumab) ${ }^{41}$
Risk-sharing schemes/ Other

payment by results

(ie, improvement in medical benefit) level:

"improvement in medical benefit" I - 36 months;

"improvement in medical benefit" II - 24 months;

"improvement in medical benefit" III - 24 months at $50 \%$; and "improvement in medical benefit"

IV - 24 months at $25 \%$

-Also applies to "orphan drugs" (eg, eculizumab for paroxysmal nocturnal hemoglobinuria and galsulfase for mucopolysaccharidosis type VI) ${ }^{41}$

For pharmaceuticals

Financially based:

- Price-volume agreements

- "target agreements": if prescription

volume target is exceeded by $25 \%$, manufacturers must "pay back" sickness funds (eg, insulin analogs, olanzapine, risperidone, clopidogrel, zolendronate, mycophenolic acid, everolimus, and cyclosporine) $)^{41}$

No information found

Financially based:

- Price-volume agreements

- $12 \%$ of reimbursed sales must be paid to the Ministry by the manufacturer

- If Ministry spending on pharmaceutical exceeds agreed-to budget, the manufacturer must refund the Ministry an additional amount based on a predefined formula ${ }^{41}$

No information found

Clinically based:

- Pharmaceutical initially reimbursed by National Health Service at $50 \%$ or $100 \%$ for a fixed number of treatment cycles, after which it is only reimbursed for patients achieving predefined clinical response; manufacturer may be required to refund the cost of pharmaceutical in non-responding patients (eg, sunitinib, sorafenib, dasatinib, and nilotinib)

- Registries used to track outcomes included in scheme ${ }^{47}$

- Manufacturer initially provides pharmaceutical at no cost for a fixed period, after which National Health Service pays for pharmaceutical in patients achieving predefined clinical response (eg, donepezil) ${ }^{41}$
- No reimbursement limit for potentially effective technologies used to manage life-threatening technologies for which there are no alternatives ${ }^{82}$

No information found

No information found

No information found

- Individual reimbursement

- Patients may be granted individual reimbursement of pharmaceuticals not on the benefit list if:

I) No alternative exists

2) Requested pharmaceutical is available in other European Union states

3) Clinical trials are underway

4) Pharmaceutical is already reimbursed for a different indication 96,205

- Establishment of "innovative medicines fund"

- Commits $20 \%$ of available resources to reimbursement of "innovative" pharmaceuticals, ranked from most to least innovative using the following criteria: I) Treats serious conditions that are lifethreatening or cause hospitalization or permanent disability 
Table 7 (Continued)

\begin{tabular}{llll}
\hline Country & $\begin{array}{l}\text { Centralized reimbursement } \\
\text { review/decision-making body } \\
(\text { role })\end{array}$ & \begin{tabular}{l} 
Policy options for addressing decision-making uncertainties \\
\cline { 2 - 4 }
\end{tabular} & Reassessment \\
\hline
\end{tabular}

$\begin{array}{ll}\text { Norway } & \text { Norwegian Medicines Agency } \\ & (\text { recommendations/decisions) })^{34,98} \\ - & \text { Ministry of Health and Care Services } \\ & (\text { recommendations/decisions) } \\ - & \text { Department of Pharmacoeconomics } \\ & (\text { recommendations })^{98}\end{array}$

Poland

Portugal

Scotland

Spain

Sweden

Switzerland
- Ministry of Health (decisions) ${ }^{99}$

- Drug Management Team (recommendations) ${ }^{99}$

- Ministry of Health (decisions)

- INFARMED (recommendations) 44,101
- National Health Service Scotland (decisions) ${ }^{30}$

- Scottish Medicines Consortium (recommendations)

- Ministry of Health (decisions)

- Reimbursement Committee for Medicinal Products (recommendations) 105,106

- Ministry of Health Directorate General of Pharmacy and Health Products; Inter-Ministerial Pricing Commission (decisions) ${ }^{21,108}$

- Dental and Pharmaceutical Benefits Board Expert Board (decisions) ${ }^{15,206-209}$
- Pharmaceuticals may be reassessed as part of ongoing therapeutic class reviews ${ }^{34}$
No information found

No information found

No information found
- Swiss Federal Office of Public

Health (decisions)

- Federal Drug Commission

(recommendations) $)^{113,114}$
- Yes - for all pharmaceuticals

- Automatic reassessment, but review period varies with the pharmaceutical; depends upon when additional evidence is expected to be available ${ }^{128}$

No information found

No information found

- Yes - for all pharmaceuticals

- Automatic reassessment, but review period varies with the pharmaceutical; depends upon when additional evidence is expected to be available ${ }^{51,135}$

- Pharmaceuticals may also be reassessed as part of ongoing therapeutic class reviews $s^{5,1,35}$

No information found
No information found

No information found

No information found

\footnotetext{
- Reimbursement price may be adjusted to reflect actual costs and benefits once such information becomes available (eg, continuous intraduodenal infusion of levodopa/carbidopa for advanced Parkinson's disease) $)^{209}$

- "Innovation premium" - Granted to innovative pharmaceuticals (ie, therapeutic breakthrough products)
} 
Reimbursement as part

of a formal study

No information found

No information found

No information found

No information found

No information found

No information found

- May require submission of evidence from studies collecting "real-world" data on clinical, economic, and quality of life outcomes ${ }^{205,209}$
Risk-sharing schemes/ payment by results

Financially based:

- Expenditure cap

- Cost per patient per year

cannot exceed a certain amount

(eg, bevacizumab) $)^{41}$

No information found

No information found

Financially based:

- Price-volume agreements

- Growth rate in pharmaceutical expenditures fixed per year; if exceeded, manufacturers must refund the system up to $69.6 \%$ of the coverage up to a predetermined amount, eg, $€ 35$ million (2006) ${ }^{44}$

No information found

No information found

No information found

No information found
No information found

2) Used for risk factors for serious conditions

3) Used for nonserious conditions ${ }^{25,188}$

- If fund is overspent, manufacturers participate in refunding the system proportional to market share ${ }^{95}$

- Individual reimbursement

- For patients who have exhausted all reimbursed alternatives and/or have serious or rare conditions

- May be requested by specialists only

- Reimbursement decision made by Norwegian Labour and Welfare Organization

- Pharmaceutical does not need to have obtained market approval ${ }^{34}$

No information found

No information found

No information found

No information found

No information found 
Table 7 (Continued)

$\begin{array}{ll}\text { Country } & \text { Centralized reimbursement } \\ \text { review/decision-making body }\end{array}$
(role)

The

Netherlands
- Ministry of Health, Welfare and Sport (decisions)

- Dutch Healthcare Insurance Board Committee of the Dutch Healthcare Insurance Board (recommendations) $^{31}$
- Yes - for all pharmaceuticals

- Automatic reassessment - time period not specified $^{31,210,211}$
Policy options for addressing decision-making uncertainties

Reassessment

Value-based pricing/ reimbursement

- Surcharge of $\leq 20 \%$ of external reference price is added for a maximum of 15 years $^{113,114,205}$

No information found

$\begin{array}{ll}\text { United } & - \text { National Institute for Health } \\ \text { Kingdom } & \text { and Clinical Excellence (decisions) } \\ & - \text { Technology Appraisals Committee } \\ & \text { (recommendations) }\end{array}$

- Yes - for all technologies

- Automatic reassessment, but review period varies with the pharmaceutical; depends upon when additional evidence is expected to be available ${ }^{13,29,157}$

\footnotetext{
- Proposed "flexible pricing" scheme:

- Manufacturers can adjust the price of a pharmaceutical in response to emerging additional evidence on actual benefit or approval of a new indication which alters the value that the pharmaceutical offers to patients

- National Institute for Health and Clinical Excellence assesses whether new price and evidence represents "value for money" and may veto a new price on an existing indication ${ }^{45,48}$
} 
Reimbursement as part

of a formal study
Risk-sharing schemes/

payment by results
Other

No information found

No information found projected costs $>5 \%$ of hospital budget

- Granted provisional reimbursement for 3 years, during which studies collecting "real-world" data on cost-effectiveness must be conducted" 19 High-cost pharmaceuticals for rare conditions

- Granted provisional reimbursement for use in an academic hospital for 4 years, during which manufacturer must sponsor studies collecting "real-world" data on cost effectiveness and budget impact ${ }^{119}$

- "Innovation pass"

- Selected "innovative" technologies are made available for 3 years, during which studies to collect data needed to inform standard National Institute for Health and Clinical Excellence processes are conducted ${ }^{48}$
For pharmaceuticals

"Patient access schemes" 42

Financially based:

- Manufacturer proposes discounts or rebates to reduce the cost of a pharmaceutical to the National Health Service, thus improving its cost-effectiveness

- Manufacturer must obtain approval for such a scheme from the Department of Health prior to National Institute for Health and Clinical Excellence review $29,212-214$

- Expenditure cap

- Cost per patient per year cannot exceed a certain amount (eg, ustekinumab and erlotinib) ${ }^{45}$ Clinically based:

- Manufacturer covers the cost of initial fixed number of cycle(s) of treatment, after which National Health Service pays for patients achieving predefined clinical response (eg, sunitinib) ${ }^{45}$

- National Health Service covers the cost of initial fixed number of cycles of treatment, after which manufacturer refunds the cost of treatment in patients failing to achieve predefined clinical response (eg, bortezomib) ${ }^{40}$

- National Health Service covers the cost of the pharmaceutical for a fixed period, after which the price is reduced or refunds are issued to achieve predefined ICER (eg, interferon $\beta$, glatiramer acetate, and azathioprine $)^{45}$
- End-of-life medicines guidance

- Pharmaceuticals used to extend life by at least 3 months for patients with less than 24 months to live may be reimbursed, even if ICER exceeds threshold range ${ }^{37-48}$

- Pharmaceuticals for rare conditions guidance

- May be reimbursed when ICER exceeds threshold range if:

- Target conditions in which incidence $<7000$ patients/year in the UK

- There is sufficient evidence demonstrating that pharmaceutical offers substantial average increase in life expectancy over alternatives ${ }^{205}$ 
Table 7 (Continued)

\begin{tabular}{|c|c|c|c|}
\hline \multirow[t]{2}{*}{ Country } & \multirow{2}{*}{$\begin{array}{l}\text { Centralized reimbursement } \\
\text { review/decision-making body } \\
\text { (role) }\end{array}$} & \multicolumn{2}{|c|}{ Policy options for addressing decision-making uncertainties } \\
\hline & & Reassessment & $\begin{array}{l}\text { Value-based pricing/ } \\
\text { reimbursement }\end{array}$ \\
\hline Wales & $\begin{array}{l}\text { - Ministry for Health and Social } \\
\text { Services (decisions) } \\
\text { - All Wales Medicines Strategy Group } \\
\text { New Medicines Group } \\
\text { (recommendations) }^{120}\end{array}$ & $\begin{array}{l}\text { - Yes - for all pharmaceuticals } \\
\text { - Automatic reassessment, but review } \\
\text { period varies with the pharmaceutical; } \\
\text { depends upon when additional evidence } \\
\text { is expected to be available }{ }^{174}\end{array}$ & No information found \\
\hline
\end{tabular}

considerable debate around definitions/qualifiers (eg, what constitutes "last chance"? or by what period of time must a technology lengthen survival in order to be regarded as "life-extending"?) remains. Finally, the following factors are simply listed as criteria/factors by a small proportion of committees: alignment with government priorities; feasibility; and/or risk of off-label use of the technology (Table 6).

In general, systems aim to complete single technology reviews within 180 days of submission/identification of candidate technology, the time period prescribed by the European Union Transparency Directive. Based on tracking data, the actual time required appears to depend primarily on whether the assessment report accompanies a reimbursement application (eg, Belgium) or is undertaken (internally or externally) by the system once a technology is identified for review (eg, the UK, Table 5). In the latter case, review times can be 90 days or less (eg, Denmark and France)..$^{20,38}$

The majority of systems have established mechanisms for appealing recommendations or decisions. Briefly, there are two main types of disputes, ie, those related to process and those amounting to disagreements over the interpretation of the evidence. In approximately one-third of systems, acceptable grounds for appeals are those of the first type only ("failed to act in accordance with processes" ${ }^{39}$ ). For the most part, appeals are heard by an expert panel appointed by the respective health care organization or "payer" (eg, Ministry of Health, Table 5). Alternatively, they must be filed in an administrative court (eg, Germany and Sweden).

\section{Conditional reimbursement enabling access to new technologies}

Increasingly, reimbursement systems are expressing interest in and/or implementing reimbursement policy options that extend beyond the traditional "yes," "no," or "yes with restrictions" options. Such policy options take the form of provisional reimbursement arrangements, in which funding for a technology is provided in the interim while evidence needed to make a definitive decision is collected. ${ }^{40}$
Collectively referred to as "Access with Evidence Development" (AED) schemes, they have emerged in response to calls for mechanisms that balance access to new technologies with the need to ensure their safe, effective, and efficient introduction and use in the health care system. In recent years, these calls have heightened, as tension between payers and manufacturers, patients, and providers has intensified. Many new high-cost technologies are supported by limited, albeit promising, evidence. Therefore, reimbursement decisions are made under conditions of considerable uncertainty, with significant risks and consequences of "getting it wrong" (wasted scarce resources and poor health outcomes). AED schemes attempt to reduce such risks through "managed entry" of new technologies into everyday clinical practice. There are three main types, ie, coverage linked to an outcomes guarantee, coverage as part of a study, and automatic reassessment (Table 7). Often referred to as "risk-sharing" schemes, "patient access schemes," and "payment by results," the first type consists of contractual arrangements between payers and manufacturers, where payment is tied to the achievement of an outcome, be it financial or health-related. ${ }^{41,42}$ Such schemes have been employed in approximately one-third of the systems in this review (Table 7). They include financially-based pricevolume agreements, where manufacturers must "pay back" the cost of sales exceeding those forecasted (eg, Belgium, France, Germany, Hungary, Portugal) ${ }^{41,43,44}$ and expenditure caps, in which manufacturers cover the cost of "treatment" in patients for whom costs over a fixed time period exceed a prespecified amount (eg, Italy, the UK). ${ }^{41,45}$ Health-related risk sharing arrangements, also called "no cure no pay" schemes, have been implemented by a smaller proportion of systems (Belgium, Denmark, Italy, the UK). ${ }^{41,45-47}$ Under such schemes, continued reimbursement of a technology (usually a pharmaceutical for a rare disorder or cancer) requires evidence of a predefined treatment effect. The second type, "coverage as part of a study," involves provision of interim funding by payers in order to conduct studies designed to collect specific information needed to fill key evidence gaps. 


\section{Reimbursement as part}

of a formal study

No information found
Risk-sharing schemes/

payment by results

No information found
Other

No information found
Typically, such evidence gaps relate to the effectiveness and/ or cost implications of the technology in "real world" settings. Funding may be partial (costs of the technology and/or health care associated with its use) or full (all health care and research costs). This type of scheme constitutes a policy option in approximately one quarter of the reimbursement systems, the majority of which have mandates that span pharmaceutical and nonpharmaceutical technologies (eg, France, Germany, the UK, Table 7). Eligible technologies vary across systems, but often include those defined as "innovative" (eg, granted an "innovation pass" in the UK) and those anticipated to significantly impact health care organization budgets (eg, the Netherlands). ${ }^{25,48}$ The third type of AED scheme, "automatic reassessment," comprises a programmed review of a reimbursement decision following a fixed period on the "benefit list" or when additional evidence is available. ${ }^{4-51}$ It has become a part of the policy framework in half of the reimbursement systems included in this review, with most requiring reassessments of all technologies within their decision-making scope (Table 7). Despite the appeal of AED schemes, evidence of their effectiveness is both limited and mixed. Recent reviews have highlighted the challenges involved in both their design and implementation. ${ }^{52,53}$ Such challenges primarily stem from the need to reach consensus among stakeholders on the terms of the scheme. Often, considerable time and resources have been required to resolve disagreements over elements such as the value proposition, outcomes to be measured and for what period, how the scheme should be funded, and to whom its oversight should be handed. Further, negotiations have, in some cases, resulted in complex arrangements that failed to generate the evidence needed to support a policy decision and/or created a significant administrative burden on payers and providers involved in its implementation. In an effort to address these issues, guidelines for conducting AED schemes, derived from international experiences to date, were recently published. ${ }^{53,54}$ Moreover, some systems have proposed alternative approaches to dealing with decision uncertainties. For example, earlier this year, National Institute of Health and Clinical Excellence announced a new form of value-based reimbursement termed "flexible pricing." ${ }^{45-48}$ Under this approach, manufacturers adjust the price of a technology (pharmaceutical) in response to additional evidence of actual benefit to patients as it emerges. The National Institute of Health and Clinical Excellence subsequently assess this evidence, along with the proposed price, and determines whether the technology represents "value for money." If a negative opinion is reached, the National Institute of Health and Clinical Excellence may veto the proposed price. Given the potential benefits of such an approach (eg, reduced administrative burden and system resource requirements) it has already sparked interest among the National Institute of Health and Clinical Excellence's counterparts across Europe.

\section{Role of manufacturers in steps comprising the reimbursement review process}

Few reimbursement systems have established roles for manufacturers beyond referral of a technology for review and the opportunity to comment on draft reports and/or preliminary recommendations (Table 8). Where "multiple technology appraisal" processes exist and assessment reports are commissioned or undertaken by the reimbursement system, manufacturers may participate in defining the scope or protocol of the assessment (France, Germany, the UK) or submit information to the group preparing such reports (Germany, Ireland, Spain, the UK). Among systems that prepare the evaluation report only, about half invite manufacturers to contribute information (Scotland, Italy, Sweden, the UK, Wales). Involvement of manufacturers otherwise appears limited to single examples, eg, able to participate in consultations during the assessment (France) or attend review committee meetings (Wales).

\section{Conclusion}

Centralized reimbursement systems have become an important policy tool in many European countries. Their introduction has, inarguably, brought greater consistency to 
Table 8 Comparison of the role of manufacturers in centralized reimbursement processes

\begin{tabular}{|c|c|c|c|c|c|c|}
\hline Country & $\begin{array}{l}\text { Centralized } \\
\text { reimbursement } \\
\text { review/decision- } \\
\text { making body (role) }\end{array}$ & $\begin{array}{l}\text { Refer technology } \\
\text { topics for } \\
\text { reimbursement } \\
\text { consideration }\end{array}$ & $\begin{array}{l}\text { Participate in } \\
\text { defining scope } \\
\text { and/or protocol } \\
\text { of assessment }\end{array}$ & $\begin{array}{l}\text { Comment } \\
\text { on draft } \\
\text { protocol }\end{array}$ & $\begin{array}{l}\text { Participate in } \\
\text { consultations } \\
\text { during } \\
\text { assessment }\end{array}$ & $\begin{array}{l}\text { Submit information } \\
\text { to group preparing } \\
\text { assessment report }\end{array}$ \\
\hline Austria & $\begin{array}{l}\text { - Association of } \\
\text { Austrian Social } \\
\text { Security Institutions } \\
\text { (decisions) }^{55} \\
\text { - Pharmaceutical } \\
\text { Evaluation Board } \\
\text { (recommendations) })^{56}\end{array}$ & Yes & $\mathrm{N} / \mathrm{A}$ & $\mathrm{N} / \mathrm{A}$ & $\mathrm{N} / \mathrm{A}$ & $\mathrm{N} / \mathrm{A}$ \\
\hline Belgium & $\begin{array}{l}\text { - Minister of Social } \\
\text { Affairs (decisions) } \\
\text { - Drug Reimbursement } \\
\text { Committee } \\
\text { (recommendations) }{ }^{9,60}\end{array}$ & Yes & $\mathrm{N} / \mathrm{A}$ & $\mathrm{N} / \mathrm{A}$ & $\mathrm{N} / \mathrm{A}$ & $\mathrm{N} / \mathrm{A}$ \\
\hline $\begin{array}{l}\text { Czech } \\
\text { Republic }\end{array}$ & $\begin{array}{l}\text { - State Institute for } \\
\text { Drug Control } \\
\text { (decisions) }^{65,176}\end{array}$ & Yes & $\mathrm{N} / \mathrm{A}$ & $\mathrm{N} / \mathrm{A}$ & $\mathrm{N} / \mathrm{A}$ & $\mathrm{N} / \mathrm{A}$ \\
\hline Denmark & $\begin{array}{l}\text { - Danish Medicines } \\
\text { Agency (decisions) } \\
\text { - Reimbursement } \\
\text { Committee } \\
\text { (recommendations) } \text { (r8, } 121^{61}\end{array}$ & Yes & $\mathrm{N} / \mathrm{A}$ & $\mathrm{N} / \mathrm{A}$ & $\mathrm{N} / \mathrm{A}$ & $\mathrm{N} / \mathrm{A}$ \\
\hline Estonia & 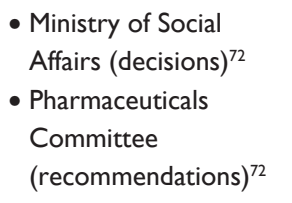 & Yes & $\mathrm{N} / \mathrm{A}$ & $\mathrm{N} / \mathrm{A}$ & $\mathrm{N} / \mathrm{A}$ & $\mathrm{N} / \mathrm{A}$ \\
\hline Finland & $\begin{array}{l}\text { - Pharmaceuticals } \\
\text { Pricing Board } \\
\text { (decisions) }^{73,74,76} \\
\text { - Pharmaceuticals } \\
\text { Pricing Board } \\
\text { Expert Group } \\
\text { (recommendations) }^{75}\end{array}$ & Yes & $N / A$ & $\mathrm{~N} / \mathrm{A}$ & $\mathrm{N} / \mathrm{A}$ & $\mathrm{N} / \mathrm{A}$ \\
\hline France & 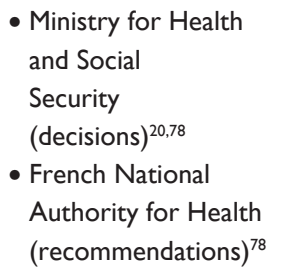 & Yes & $\begin{array}{l}\text { Yes (multiple } \\
\text { technology } \\
\text { appraisals) } \\
\text { N/A (single } \\
\text { technology } \\
\text { appraisals) }\end{array}$ & No & $\begin{array}{l}\text { Yes (multiple } \\
\text { technology } \\
\text { appraisals) } \\
\text { N/A (single } \\
\text { technology } \\
\text { appraisals) }\end{array}$ & $\begin{array}{l}\text { No (multiple } \\
\text { technology appraisals) } \\
\text { N/A (single } \\
\text { technology appraisals) }\end{array}$ \\
\hline Germany & $\begin{array}{l}\text { - Federal Joint } \\
\text { Committee } \\
\text { (decisions) }^{19} \\
\text { - Institute for } \\
\text { Quality and Efficiency } \\
\text { in Health Care } \\
\text { (recommendations) }{ }^{19}\end{array}$ & No & Yes & Yes & No & Yes \\
\hline Greece & $\begin{array}{l}\text { - Transparency } \\
\text { Committee in the } \\
\text { Reimbursement and } \\
\text { Medicinal Products } \\
\text { (makes decisions) }^{85}\end{array}$ & Yes & $N / A$ & $N / A$ & $N / A$ & N/A \\
\hline
\end{tabular}




\begin{tabular}{llllll}
\hline $\begin{array}{l}\text { Submit information } \\
\text { to group preparing } \\
\text { evaluation report }\end{array}$ & $\begin{array}{l}\text { Present views } \\
\text { during committee } \\
\text { meetings }\end{array}$ & $\begin{array}{l}\text { Nominate clinical and/or } \\
\text { patient experts to make } \\
\text { oral presentation } \\
\text { to committee }\end{array}$ & $\begin{array}{l}\text { Attend } \\
\text { committee } \\
\text { meeting }\end{array}$ & $\begin{array}{l}\text { Comment on } \\
\text { report and/or draft } \\
\text { recommendations }\end{array}$ & $\begin{array}{l}\text { Appeal } \\
\text { recommendations } \\
\text { or decisions }\end{array}$ \\
\hline No & No & No & No & Yes
\end{tabular}

No

No information
found

No

No information

found

No

No

No

No

No

No

No

No information

found

No
No information

found
No information

found

No information

found

No

No information

found

No information

found

Yes, if

recommendation

is negative

No

Yes

Yes

No

Yes

Yes (decisions only)

No information

found

Yes

es

$\begin{array}{lll}\begin{array}{l}\text { No information } \\ \text { found }\end{array} & \begin{array}{l}\text { No information } \\ \text { found }\end{array} & \text { Yes } \\ \text { No } & \begin{array}{l}\text { Yes, if } \\ \text { recommendation } \\ \text { is negative }\end{array} & \text { Yes } \\ \begin{array}{lll}\text { No information } \\ \text { found }\end{array} & \begin{array}{l}\text { No information } \\ \text { found }\end{array} & \begin{array}{l}\text { No information } \\ \text { found }\end{array}\end{array}$

es

(n)

No information

found $\begin{array}{ll}\text { No information } & \text { No information } \\ \text { found } & \text { found }\end{array}$

No information

found 
Table 8 (Continued)

\begin{tabular}{|c|c|c|c|c|c|c|}
\hline Country & $\begin{array}{l}\text { Centralized } \\
\text { reimbursement } \\
\text { review/decision- } \\
\text { making body (role) }\end{array}$ & $\begin{array}{l}\text { Refer technology } \\
\text { topics for } \\
\text { reimbursement } \\
\text { consideration }\end{array}$ & $\begin{array}{l}\text { Participate in } \\
\text { defining scope } \\
\text { and/or protocol } \\
\text { of assessment }\end{array}$ & $\begin{array}{l}\text { Comment } \\
\text { on draft } \\
\text { protocol }\end{array}$ & $\begin{array}{l}\text { Participate in } \\
\text { consultations } \\
\text { during } \\
\text { assessment }\end{array}$ & $\begin{array}{l}\text { Submit information } \\
\text { to group preparing } \\
\text { assessment report }\end{array}$ \\
\hline Hungary & $\begin{array}{l}\text { - Ministers of Health } \\
\text { and Finance } \\
\text { - National Health } \\
\text { Insurance Fund } \\
\text { Administration } \\
\text { (recommendations) }^{88}\end{array}$ & Yes & $\mathrm{N} / \mathrm{A}$ & N/A & $\mathrm{N} / \mathrm{A}$ & $N / A$ \\
\hline Ireland & $\begin{array}{l}\text { - Health Service } \\
\text { Executive } \\
\text { (decisions) }^{9,92,147}\end{array}$ & Yes & $N / A$ & $\mathrm{~N} / \mathrm{A}$ & $\mathrm{N} / \mathrm{A}$ & Yes \\
\hline Italy & $\begin{array}{l}\text { - Italian Medicines } \\
\text { Agency Technical } \\
\text { Scientific Committee } \\
\text { (decisions) }^{94} \\
\text { - Italian Medicines } \\
\text { Agency Pricing and } \\
\text { Reimbursement } \\
\text { Committee } \\
\text { (recommendations) }^{95}\end{array}$ & Yes & $N / A$ & $N / A$ & $N / A$ & No \\
\hline Norway & 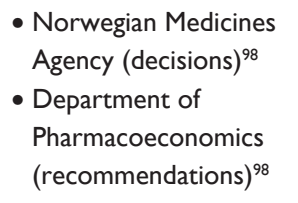 & Yes & $N / A$ & N/A & N/A & $\begin{array}{l}\text { No information } \\
\text { found }\end{array}$ \\
\hline Poland & $\begin{array}{l}\text { - Ministry of Health } \\
\text { (decisions) }{ }^{99,166}\end{array}$ & Yes & $N / A$ & $\mathrm{~N} / \mathrm{A}$ & $N / A$ & $\begin{array}{l}\text { No information } \\
\text { found }\end{array}$ \\
\hline Portugal & $\begin{array}{l}\text { - Ministry of Health } \\
\text { (decisions) } \\
\text { - INFARMED } \\
\text { (recommendations) })^{36,44}\end{array}$ & Yes & $\mathrm{N} / \mathrm{A}$ & $\mathrm{N} / \mathrm{A}$ & $\mathrm{N} / \mathrm{A}$ & $\begin{array}{l}\text { No information } \\
\text { found }\end{array}$ \\
\hline Scotland & $\begin{array}{l}\text { - National Health } \\
\text { Service Scotland } \\
\text { (decisions) } \\
\text { - Scottish Medicines } \\
\text { Consortium } \\
\text { (recommendations) }\end{array}$ & Yes & $N / A$ & $N / A$ & $N / A$ & No \\
\hline Slovakia & $\begin{array}{l}\text { - Ministry of Health } \\
\text { (decisions) } \\
\text { - Reimbursement } \\
\text { Committee for } \\
\text { Medicinal Products } \\
\text { (recommendations) }^{105-107}\end{array}$ & Yes & $N / A$ & N/A & $N / A$ & $\begin{array}{l}\text { No information } \\
\text { found }\end{array}$ \\
\hline Spain & $\begin{array}{l}\text { Ministry of Health } \\
\text { Directorate General } \\
\text { of Pharmacy and } \\
\text { Health Products; } \\
\text { Inter-Ministerial } \\
\text { Pricing Commission } \\
\text { (decisions) })^{21,108}\end{array}$ & No & No & No & Yes & Yes \\
\hline Sweden & $\begin{array}{l}\text { - Dental and } \\
\text { Pharmaceutical } \\
\text { Benefits Board } \\
\text { Expert Board } \\
\text { (decisions) }^{10,104,105}\end{array}$ & Yes & $\mathrm{N} / \mathrm{A}$ & $\mathrm{N} / \mathrm{A}$ & $\mathrm{N} / \mathrm{A}$ & $\mathrm{N} / \mathrm{A}$ \\
\hline
\end{tabular}




\begin{tabular}{llllll}
\hline $\begin{array}{l}\text { Submit information } \\
\text { to group preparing } \\
\text { evaluation report }\end{array}$ & $\begin{array}{l}\text { Present views } \\
\text { during committee } \\
\text { meetings }\end{array}$ & $\begin{array}{l}\text { Nominate clinical and/or } \\
\text { patient experts to make } \\
\text { oral presentation } \\
\text { to committee }\end{array}$ & $\begin{array}{l}\text { Attend } \\
\text { committee } \\
\text { meeting }\end{array}$ & $\begin{array}{l}\text { Comment on } \\
\text { report and/or draft } \\
\text { recommendations }\end{array}$ & $\begin{array}{l}\text { Appeal } \\
\text { recommendations } \\
\text { or decisions }\end{array}$ \\
\hline $\begin{array}{l}\text { No information } \\
\text { found }\end{array}$ & $\begin{array}{l}\text { No information } \\
\text { found }\end{array}$ & $\begin{array}{l}\text { No information } \\
\text { found }\end{array}$ & $\begin{array}{l}\text { No information } \\
\text { found }\end{array}$ & $\begin{array}{l}\text { No information } \\
\text { found }\end{array}$ & Yes \\
No & No & No & No & Yes & Yes \\
Yes & No & No & No & Yes
\end{tabular}

$\begin{array}{llllll}\begin{array}{l}\text { No information } \\ \text { found }\end{array} & \begin{array}{l}\text { No information } \\ \text { found }\end{array} & \begin{array}{l}\text { No information } \\ \text { found }\end{array} & \begin{array}{l}\text { No information } \\ \text { found }\end{array} & \begin{array}{l}\text { No information } \\ \text { found }\end{array} & \text { Yes } \\ \begin{array}{l}\text { No information } \\ \text { found }\end{array} & \begin{array}{l}\text { No information } \\ \text { found }\end{array} & \begin{array}{l}\text { No information } \\ \text { found }\end{array} & \text { No information } & \text { No information } & \begin{array}{l}\text { No information } \\ \text { found }\end{array} \\ \text { found } & \text { No information } & \text { No information } & \text { found } & \text { No information } & \text { No information } \\ \text { found } & \text { found } & \text { found } & \text { Yes } \\ \text { Yes } & \text { No } & \text { No } & \text { No } & \text { Yes } & \text { Yes }\end{array}$

No information found

No
No information found No information
found $\begin{array}{ll}\text { No information } & \text { No information } \\ \text { found } & \text { found }\end{array}$

No

No
No
No

(2nat
Yes
Yes
Yes
No
No
Yes 
Table 8 (Continued)

\begin{tabular}{|c|c|c|c|c|c|c|}
\hline Country & $\begin{array}{l}\text { Centralized } \\
\text { reimbursement } \\
\text { review/decision- } \\
\text { making body (role) }\end{array}$ & $\begin{array}{l}\text { Refer technology } \\
\text { topics for } \\
\text { reimbursement } \\
\text { consideration }\end{array}$ & $\begin{array}{l}\text { Participate in } \\
\text { defining scope } \\
\text { and/or protocol } \\
\text { of assessment }\end{array}$ & $\begin{array}{l}\text { Comment } \\
\text { on draft } \\
\text { protocol }\end{array}$ & $\begin{array}{l}\text { Participate in } \\
\text { consultations } \\
\text { during } \\
\text { assessment }\end{array}$ & $\begin{array}{l}\text { Submit information } \\
\text { to group preparing } \\
\text { assessment report }\end{array}$ \\
\hline Switzerland & $\begin{array}{l}\text { - Swiss Federal Office of } \\
\text { Public Health } \\
\text { (decisions) } \\
\text { - Federal Drug } \\
\text { Commission } \\
\text { (recommendations) })^{1 / 3,1 / 4}\end{array}$ & Yes & $\mathrm{N} / \mathrm{A}$ & $\mathrm{N} / \mathrm{A}$ & $\mathrm{N} / \mathrm{A}$ & $\mathrm{N} / \mathrm{A}$ \\
\hline $\begin{array}{l}\text { The } \\
\text { Netherlands }\end{array}$ & $\begin{array}{l}\text { - Ministry of Health, } \\
\text { Welfare and Sport } \\
\text { (decisions) } \\
\text { - Dutch Healthcare } \\
\text { Insurance Board } \\
\text { Committee of the } \\
\text { Dutch Healthcare } \\
\text { Insurance Board } \\
\text { (recommendations) }^{31}\end{array}$ & Yes & $N / A$ & $\mathrm{~N} / \mathrm{A}$ & $\mathrm{N} / \mathrm{A}$ & $\mathrm{N} / \mathrm{A}$ \\
\hline $\begin{array}{l}\text { United } \\
\text { Kingdom }\end{array}$ & $\begin{array}{l}\text { - National Institute for } \\
\text { Health and Clinical } \\
\text { Excellence (decisions) } \\
\text { - Technology } \\
\text { Appraisals Committee } \\
\text { (recommendations) }^{7}\end{array}$ & Yes & $\begin{array}{l}\text { Yes (multiple } \\
\text { technology } \\
\text { appraisals) } \\
\text { N/A (single } \\
\text { technology } \\
\text { appraisals) }\end{array}$ & $\begin{array}{l}\text { No (multiple } \\
\text { technology } \\
\text { appraisals) } \\
\text { N/A (single } \\
\text { technology } \\
\text { appraisals) }\end{array}$ & $\begin{array}{l}\text { No (multiple } \\
\text { technology } \\
\text { appraisals) } \\
\text { N/A (single } \\
\text { technology } \\
\text { appraisals) }\end{array}$ & $\begin{array}{l}\text { Yes (multiple } \\
\text { technology appraisals) } \\
\text { N/A (single } \\
\text { technology appraisals) }\end{array}$ \\
\hline Wales & $\begin{array}{l}\text { - Ministry for Health } \\
\text { and Social Services } \\
\text { (decisions) } \\
\text { - All Wales Medicines } \\
\text { Strategy Group } \\
\text { (recommendations) }^{120}\end{array}$ & Yes & $N / A$ & $\mathrm{~N} / \mathrm{A}$ & $\mathrm{N} / \mathrm{A}$ & $\mathrm{N} / \mathrm{A}$ \\
\hline
\end{tabular}

processes and an improved sense of legitimacy to decisions. Nevertheless, there remains a lack of transparency around critical elements, such as how multiple factors or criteria are weighed during committee deliberations. Further, empirical studies evaluating the extent to which centralized reimbursement systems with advisory as opposed to decision-making authority are able to reduce inequities in access to new technologies within jurisdictions appear sparse.

Given the rapid pace with which new technologies that appear promising are now entering the market and the need to work alongside broader government industrial policies for encouraging innovation in an economic climate that demands prudent use of strained health care resources, the adoption of AED schemes by reimbursement systems seems inevitable. However, until more information on the outcomes of initiatives such as flexible pricing in the UK becomes available, their implementation should be approached with caution.

\section{Disclosure}

The authors report no conflicts of interest in this work.

\section{References}

1. Mitton C, Donaldson C. Health care priority setting: Principles, practice and challenges. Cost Eff Resour Alloc. 2004;2:3-8.

2. The health of Canadians: The federal role. Final report. Volume 6: Recommendations for reform. Ottawa, ON: Government of Canada, Standing Senate Committee on Social Affairs, 2002. Available from: http://www.parl.gc.ca/Content/SEN/Committee/372/soci/rep/repoct02 vol6-e.htm. Accessed July 22, 2011.

3. Wilking N, Jonsson B. A pan-European comparison regarding patient access to cancer drugs. Stockholm, Sweden: Karolinska Institutet, 2006. Available from: http://ki.se/content/1/c4/33/52/Cancer_Report.pdf. Accessed March 13, 2011.

4. Stafinski T, Menon D, Philippon DJ, McCabe C. Health technology funding decision-making processes around the world the same, yet different. Pharmacoeconomics. 2011;29:1-21.

5. Organization for Economic Cooperation and Development. Health Technologies and Decision Making. Paris, France: Organization for Economic Cooperation and Development; 2005.

6. von der Schulenburg J, Vauth C, Mittendorf T, Greiner W. Methods for determining cost-benefit ratios for pharmaceuticals in Germany. Eur $J$ Health Econ. 2007;8 Suppl 1:S5-S31.

7. Chalkidou K. Comparative effectiveness review within the UK's National Institute for Health and Clinical Excellence. Issue Brief (Commonw Fund). 2009. Available from: http://www.common wealthfund.org/ /media/Files/Publications/Issue\%20Brief/2009/Jul/ Chalkidou/1296_Chalkidou_UK_CER_issue_brief_717.pdf. Accessed July 18, 2011. 


\begin{tabular}{|c|c|c|c|c|c|}
\hline $\begin{array}{l}\text { Submit information } \\
\text { to group preparing } \\
\text { evaluation report }\end{array}$ & $\begin{array}{l}\text { Present views } \\
\text { during committee } \\
\text { meetings }\end{array}$ & $\begin{array}{l}\text { Nominate clinical and/or } \\
\text { patient experts to make } \\
\text { oral presentation } \\
\text { to committee }\end{array}$ & $\begin{array}{l}\text { Attend } \\
\text { committee } \\
\text { meeting }\end{array}$ & $\begin{array}{l}\text { Comment on } \\
\text { report and/or draft } \\
\text { recommendations }\end{array}$ & $\begin{array}{l}\text { Appeal } \\
\text { recommendations } \\
\text { or decisions }\end{array}$ \\
\hline $\begin{array}{l}\text { No information } \\
\text { found }\end{array}$ & $\begin{array}{l}\text { No information } \\
\text { found }\end{array}$ & $\begin{array}{l}\text { No information } \\
\text { found }\end{array}$ & $\begin{array}{l}\text { No information } \\
\text { found }\end{array}$ & $\begin{array}{l}\text { No information } \\
\text { found }\end{array}$ & Yes \\
\hline
\end{tabular}

No

No

No

Yes (single technology
appraisals)
N/A (single technology
appraisals)

Yes
No
No

Yes

No
No

No

Yes
Yes

Yes
Yes
Yes
8. Institute for Quality and Efficiency in Health Care. General methods. Cologne, Germany: Institute for Quality and Efficiency in Health Care 2008. Available from: http://www.iqwig.net/methods-procedures.926. en.html. Accessed July 15, 2011.

9. Van Wilder PB, Dupont AG. Reimbursement of medicines in Belgium: Role of evidence-based medicine. Acta Clin Belg. 2009;64: $120-128$.

10. International Society for Pharmacoeconomics and Outcomes Research. Pharmacoeconomic guidelines around the world: Spain. Lawrenceville, NJ: International Society for Pharmacoeconomics and Outcomes Research; 2010. Available from: http:// www.ispor.org/PEguidelines $/$ countrydet.asp? $=20 \& t=4$. Accessed July 22, 2011.

11. Cleemput I, Van WP, Huybrechts M, Vrijens F. Belgian methodological guidelines for pharmacoeconomic evaluations: Toward standardization of drug reimbursement requests. Value Health. 2009;12:441-449.

12. Greiner W, Kuhlmann A, Schwarzbach C. An economic evaluation of the IQWiGs efficient frontier. Gesundheitsokonomie und Qualitatsmanagement. 2010;15:241-250. German.

13. Guide to the multiple technology appraisal process. London, UK: National Insitute for Health and Clinical Excellence; 2009. Available from: http://www.nice.org.uk/media/916/6B/Guide_to_the_MTAproof_8-26-10-09.pdf. Accessed July 15, 2011.

14. Faulkner E, Matuszewski K, Niziol C. ISPOR global health care systems road map: Sweden. Lawrenceville, NJ: International Society for Pharmacoeconomics and Outcomes Research; 2009. Available from: http://www.ispor.org/HTARoadMaps/Sweden.asp. Accessed July 15, 2011.
15. Guidelines for companies: The Swedish Pharmaceutical Benefits Board (LFN). Stockholm, Sweden: Swedish Pharmaceutical Benefits Board; 2008. Available from: http://www.tlv.se/Upload/English/Guidelinesfor-Companies.pdf. Accessed July 15, 2011.

16. Le Pen C. Pricing and reimbursement policies in France: Current and future trends. In: Garau M, Mestre-Ferrandiz J, editors. European Medicines Pricing and Reimbursement. Milton Keynes, UK: Radcliffe Publishing; 2007. Available from: http://www.radcliffe-oxford.com/books/samplechapter/184X/ Garau_CHPT1-5e62f200rdz.pdf. Accessed July 22, 2011.

17. Cleemput I, van Wilder PV, Vrijens F, Huybrechts M, Ramaekers D. Guidelines for Pharmacoeconomic Evaluations in Belgium [KCE Reports 78C]. Brussels, Belgium: Belgian Health Care Knowledge Centre. 2008. Available from: www.kce.fgov.be/Download. aspx?ID=1081. Accessed July 15, 2011.

18. Nasser M, Sawicki P. Institute for quality and efficiency in health care: Germany. Issue Brief (Commonw Fund). 2009;57:1-12. Available from: http://www.commonwealthfund.org/ /media/Files/Publications/ Issue\%20Brief/2009/Jul/Chalkidou/1294_Nasser_CER_Germany_ issue_brief_724.pdf. Accessed July 15, 2011.

19. The Federal Joint Committee: About us. Berlin, Germany: Gemeinsamer Bundesausschuss, Institut fur Qualitat und Wirtschaftlichkeit in Gesundheitswesen; 2010. Available from: http://www.g-ba.de/downloads/17-982804/2010-01-01-Faltblatt-GBA_engl.pdf. Accessed July 15, 2011.

20. Rochaix L, Xerri B. National Authority for Health: France. Issue Brief (Commonw Fund). 2009;58]. New York: The Commonwealth Fund; 2009. Available from: http://www.commonwealthfund.org/Content/ Publications/Issue-Briefs/2009/Jul/National-Authority-for-HealthFrance.aspx. Accessed July 15, 2011. 
21. Habl C, Antony K, Arts D, et al. Surveying, assessing and analysing the pharmaceutical sector in the $25 \mathrm{EU}$ member states: Country profiles. Vienna: European Commission; Osterreichisches Bundesinstitut fur Gesundheitswesen; 2006. Available from: http://ec.europa.eu/competi tion/mergers/studies_reports/oebig.pdf. Accessed July 15, 2011.

22. Chicoye A, Levesque K. ISPOR global health care systems road map: France - Medical devices. Lawrenceville, NJ: International Society for Pharmacoeconomics and Outcomes Research; 2010. Available from : http://www.ispor.org/htaroadmaps/FranceMD.asp. July 15, 2011.

23. Sermet C, Andrieu V, Godman B, Van GE, Haycox A, Reynier JP. Ongoing pharmaceutical reforms in France: Implications for key stakeholder groups. Appl Health Econ Health Policy. 2010;8:7-24.

24. General methods for the assessment of the relation of benefits to costs. Version 1.0. Cologne, Germany: Institute for Quality and Efficiency in Health Care; 2009. Available from: http://www.iqwig.de/download/General_Methods_for_the_Assessment_of_the_Relation_of Benefits_to_Costs.pdf. Accessed July 15, 2011.

25. Criteria for ranking therapeutic innovation of new drugs and elements for supplementing the dossier for admission to the reimbursement system. Rome, Italy: AIFA - Italian Medicines Agency. Working Group on Innovative Drugs; 2007. Available from: http://www.agenziafarmaco. gov.it/allegati/integral_document.pdf. Accessed July 15, 2011.

26. Sorenson C. Use of comparative effectiveness research in drug coverage and pricing decisions: a six-country comparison. Issue Brief (Commonw Fund). 2010;91. New York: The Commonwealth Fund; 2010. Available from: http://www.commonwealthfund.org/ /media/Files/Publications/ Issue\%20Brief/2010/Jul/1420_Sorenson_Comp_Effect_intl_ib_71.pdf. Accessed July 15, 2011.

27. Lo Scalzo A, Donatini A, Orzella L, Cicchetti A, Profili S, Maresso A. Italy: Health system review [Health Systems in Transition]. Copenhagen, Denmark: European Observatory on Health Care Systems, World Health Organization Regional Office for Europe; 2009. Available from: http://www.euro.who.int/_data/assets/pdf_file/0006/87225/E93666. pdf. Accessed July 15, 2011.

28. All Wales Medicines Strategy Group. Vale of Glamorgan (Wales): Welsh Medicines Partnership; 2010. Available from: http://www.wales.nhs.uk/ sites3/home.cfm?orgid=371. Accessed July 15, 2011.

29. Guide to the single technology appraisal (STA) process. London, UK: National Insitute for Health and Clinical Excellence (NICE); 2009. Available from: http://www.nice.org.uk/media/913/06/Guide_to_the_ STA-proof_6-26-10-09.pdf. Accessed July 15, 2011.

30. Guidance to manufacturers for completion of new product assessment form (NPAF). Revised June 2010. Glasgow, Scotland: Scottish Medicines Consortium; 2010. Available from: http://www.scottishmedicines. org.uk/files/submissionprocess/New_Product_Assessment_Form_ NPAF_Guidance_Notes_updated_February_2011_Final.doc. Accessed July 22, 2011.

31. Zuidberg $\mathrm{C}$, editor. Pharmaceutical Pricing and Reimbursement Information. The pharmaceutical system of the Netherlands. Vienna, Austria: 2010. Available from: http://ppri.oebig.at/Downloads/ Publications/The \%20pharmaceutical\%20system\%20of\%20the $\% 20$ Netherlands_FINAL.pdf. Accessed July 15, 2011.

33. Daniels N, Sabin JE. Last chance therapies and managed care. Pluralism, fair procedures, and legitimacy. Hastings Cent Rep. 1998;28:27-41.

34. Sjogren E. Deciding subsidy for pharmaceuticals based on ambiguous evidence. $J$ Health Organ Manag. 2008;22:368-383.

35. Pharmaceutical pricing and reimbursement information: Norway. Vienna, Austria: Pharmaceutical Pricing and Reimbursement Information; 2008. Available from: http://ppri.oebig.at/Downloads/Results/ Norway_PPRI_2008.pdf. Accessed July 15, 2011.

36. Sorenson C, Drummond M, Kanavos P. Ensuring value for money in health care: the role of health technology assessment in the European Union [European Observatory on Health Systems and Policies. Observatory Studies Series No. 11]. Copenhagen, Denmark: World Health Organization Regional Office for Europe; 2008. Available from: http:// www.euro.who.int/_data/assets/pdf_file/0011/98291/E91271.pdf. Accessed July 15, 2011.
36. Teixeira I, Agostinho I. Pharmaceutical pricing and reimbursement information: Lisbon, Portugal: Pharmaceutical Pricing and Reimbursement Information; 2008. Available from: http://www.infarmed.pt/portal/ page/portal/INFARMED/MONITORIZACAO_DO_MERCADO/ OBSERVATORIO/Projectos_Internacionais/Portugal_PPRI_2008.pdf. Accessed July 15, 2011.

37. Appraising life-extending, end of life treatments. London, UK: National Institute for Health and Clinical Excellence (NICE); 2009. Available from: http://www.nice.org.uk/aboutnice/howwework/devnicetech/ endoflifetreatments.jsp. Accessed July 15, 2011.

38. Guidelines for application for general reimbursement of medicinal products. Copenhagen, Denmark: The Danish Medicines Agency; 2008. Available from: http://laegemiddelstyrelsen.dk/ /media/31 C93DCD939A43FBB9E20070B5548337.ashx. Accessed July 22, 2011.

39. 2000/030 summary of the appeals process. London, UK: National Insitute for Health and Clinical Excellence (NICE); 2000. Available from: http://www.nice.org.uk/newsroom/pressreleases/pressreleasearchive/pressreleases2000/2000_030_summary_of_the_appeals_process.jsp. Accessed January 7, 2010.

40. Stafinski T, McCabe CJ, Menon D. Funding the unfundable: Mechanisms for managing uncertainty in decisions on the introduction of new and innovative technologies into healthcare systems. Pharmacoeconomics. 2010;28:113-142.

41. Adamski J, Godman B, Ofierska-Sujkowska G, et al. Risk sharing arrangements for pharmaceuticals: Potential considerations and recommendations for European payers. BMC Health Serv Res. 2010;10:153. Available from: http://www.biomedcentral.com/1472-6963/10/153. Accessed July 15, 2011

42. Garner S. How does NICE value innovation? Drug Dev Res. 2010;71:449-456.

43. Grandfils N. Drug price setting and regulation in France [Working paper no. 16]. Paris, France: Institut de recherche et documentation en economie de la sante (IRDES); 2008. Available from: http://www.irdes. $\mathrm{fr} /$ EspaceAnglais/Publications/WorkingPapers/DT16DrugPriceSettingRegulationFrance.pdf. Accessed July 15, 2011.

44. Barros PP, de Almeida Simoes J. Allin S, Mossialos E, editors. Portugal: Health system review [Health Systems in Transition 2007;9(5)]. Copenhagen, Denmark: World Health Organization Regional Office for Europe. European Observatory on Health Systems and Policies; 2007. Available from: http://www.euro.who.int/data/assets/pdf file/0004/107842/E90670.pdf. Accessed July 15, 2011.

45. Briggs A, Ritchie K, Fenwick E, Chalkidou K, Littlejohns P. Access with evidence development in the UK: Past experience, current initiatives and future potential. Pharmacoeconomics. 2010;28: 163-170.

46. The Danish Medicines Agency: Reimbursement. Copenhagen, Denmark: The Danish Medicines Agency; 2010. Available from: http:// laegemiddelstyrelsen.dk/en/topics/statistics,-prices-and-reimbursement/ reimbursement-of-medicines. Accessed July 22, 2011.

47. Tonarelli L. Italy: Pioneering pay for performance in the age of austerity. InPharm News(InPharm com) 2011. Available from: http://www.inpharm. com/news/110104/italy-drug-price-cuts. Accessed July 22, 2011.

48. Towse A. Value based pricing, research and development, and patient access schemes. Will the United Kingdom get it right or wrong? $\mathrm{Br} J$ Clin Pharmacol. 2010;70:360-366.

49. Le Polain M, Franken M, Koopmanschap M, Cleemput I. Drug reimbursement systems: International comparison and policy recommendations. Brussels, Belgium: Belgian Health Care Knowledge Centre; 2010. Available from: http://www.kce.fgov.be/ index_en.aspx?SGREF=5211\&CREF=18732. Accessed July 22, 2011.

50. Guidelines on procedure for reassessment of reimbursement status. Copenhagen, Denmark: Danish Medicines Agency; 2005. Available from: http:// laegemiddelstyrelsen.dk/en/topics/statistics,-prices-and-reimbursement/ reimbursement-of-medicines/general-reimbursement/reassessment-of-reimbursement-status-for-1-products/guidelines/guidelines-on-procedurefor-reassessment-ent-status. Accessed July 22, 2011. 
51. Welcome to TLV [the Dental and Pharmaceutical Benefits Agency]. Stockholm, Sweden: Dental and Pharmaceutical Benefits Agency; 2008. Available from: http://www.tlv.se/in-english-old/in-english/. Accessed July 22, 2011.

52. McLaughlin N. Of problems and solutions. Issues with variable-rate bonds, medical errors led our recent coverage. Mod Healthc. 2009;39:18.

53. McCabe CJ, Stafinski T, Edlin R, Menon D. Access with evidence development schemes: A framework for description and evaluation. Pharmacoeconomics. 2010;28:143-152.

54. Menon D, McCabe CJ, Stafinski T, Edlin R. Principles of design of access with evidence development approaches: A consensus statement from the Banff Summit. Pharmacoeconomics. 2010;28:109-111.

55. Buchholz P. ISPOR global health care systems road map: Austria Pharmaceuticals. Lawrenceville, NJ: International Society for Pharmacoeconomics and Outcomes Research; 2009. Available from: http://www. ispor.org/htaroadmaps/Austria.asp. Accessed July 23, 2011.

56. Godman B, Bucsics A, Burkhardt T, Haycox A, Seyfried H, Wieninger P. Insight into recent reforms and initiatives in Austria: Implications for key stakeholders. Expert Rev Pharmacoecon Outcomes Res. 2008;8:357-371.

57. Wild C. Austria: History of health technology assessment during the past 20 years. Int J Technol Assess Health Care. 2009;25 Suppl 1:74-81.

58. Pharmaceutical pricing and reimbursement information: Austria. [Pharmaceutical Pricing and Reimbursement Information]. Vienna, Austria: European Commission, Health and Consumer Protection Directorate-General and Austrian Ministry of Health, Family and Youth; 2008. Available from: http://ppri.oebig.at/Downloads/Results/ Austria_PPRI_2008_Englih_Version.pdf. Accessed July 23, 2011.

59. Hofmarcher MM, Rack HM, Rohrling G. Austria: Health system review [Health Systems in Transition]. Copenhagen, Denmark: European Observatory on Health Care Systems, World Health Organization Regional Office for Europe; 2006. Available from: http://www.euro. who.int/_data/assets/pdf_file/0009/96435/E89021.pdf. Accessed July 23, 2011.

60. Van Wilder PB, Dupont AG. Reimbursement of medicines in Belgium: Role of evidence-based medicine. Acta Clin Belg. 2009;64:120-128.

61. Cleemput I, van WP, Huybrechts M, Vrijens F. Belgian methodological guidelines for pharmacoeconomic evaluations: Toward standardization of drug reimbursement requests. Value Health. 2009;12: 441-449.

62. Belgium. In: Policies for rare diseases and orphan drugs [KCE reports 112C]. Brussels, Belgium: Belgian Health Care Knowledge Centre; 2009. Available from: http:/www.kce.fgov.be/Download. aspx?ID=2161. Accessed July 23, 2011 .

63. Arrete royal portant modification de l'arrete royal du 3 juillet 1996 portant execution de la loi relative a l'assurance obligatoire soins de sante et indemnites, coordonnee le 14 juillet 1994. [Brussels]: Ministere des Affaires Sociales de la Sante Publique et de l'Environnement; 2001 Available from: http://www.inami.fgov.be/drug/fr/drugs/reglementation/ legal-texts/pdf/arkb20011221.pdf. Accessed July 23, 2011.

64. Corens D. Belgium: Health system review [Health Systems in Transition 2007;9(2)]. Copenhagen, Denmark: World Health Organization Regional Office for Europe. European Observatory on Health Care Systems; 2007. Available from: http://www.euro.who.int/_data/assets/ pdf_file/0007/96442/E90059.pdf. Accessed July 23, 2011.

65. Prices and reimbursements of medicinal products and foods for special medical purposes. Prague, Czechoslovakia: State Institute for Drug Control; 2010. Available from: http://www.sukl.eu/sukl/prices-andreimbursements-of-medicinal-products-and-foods. Accessed July 23, 2011.

66. Bryndova L, Pavlokova K, Roubal T, Rokosova M, Gaskins M. Czech Republic: Health system review [Health Systems in Transition 2009;11(1)]. Copenhagen, Denmark: World Health Organization. Regional Office for Europe. European Observatory on Health Systems and Policies; 2009. Available from: http://www.euro. who.int/_data/assets/pdf_file/0010/97633/E92968.pdf. Accessed July 23, 2011.
67. Praznovcova L, Suchopar J, Wertheimer AI. Drug policy in the Czech Republic. In: Wertheimer AI, Smith MC, editors. International Drug Regulatory Mechanisms. Binghamton, NY: Haworth Press; 2003.

68. Pricing and reimbursement in Denmark. Copenhagen, Denmark: The Danish Association of the Pharmaceutical Industry; 2007. Available from: http://parno1.ipapercms.dk/LIF/Notater/PricingandreimbursementinDenmark/. Accessed July 23, 2011.

69. Strandberg-Larsen M, Knudsen MS. ISPOR Global Health Care Systems Road Map: Denmark. Lawrenceville, NJ: International Society for Pharmacoeconomics and Outcomes Research; 2009. Available from: http://www.ispor.org/htaroadmaps/Denmark.asp. Accessed July 23, 2011.

70. High quality care for all. NHS next stage review final report. London, UK: Department of Health; 2008. Available from: http:/www.dh.gov. uk/prod_consum_dh/groups/dh_digitalassets/@dh/@en/documents/ digitalasset/dh_085828.pdf. Accessed July 23, 2011.

71. Pedersen KM, Christiansen T, Bech M. The Danish health care system: Evolution - not revolution - in a decentralized system. Health Econ. 2005;14 Suppl 1:S41-S57.

72. Kanavos P, Vandoros S, Habicht J, de Joncheere K. Review of the Estonian pharmaceutical sector: towards the development of a national medicines policy. Copenhagen, Denmark: World Health Organization Regional Office for Europe; 2009. Available from: http://www.euro.who. int/_data/assets/pdf_file/0004/96448/E93049.pdf. Accessed July 15, 2011.

73. Decree of the Ministry of Social Affairs and Health on the priced services of the Pharmaceuticals Pricing Board. Helsinki, Finland: Finland Ministry of Social Affairs and Health; 2010. Available from: http://www.stm. fi/c/document_library/get_file?folderId=71837\&name=DLFE-14601 pdf. Accessed July 23, 2011.

74. Decree of the Ministry of Social Affairs and Health on applications and price notifications made to the Pharmaceuticals Pricing Board. Helsinki, Finland: Finland Ministry of Social Affairs and Health; 2009. Available from: http://www.ispor.org/PEguidelines/source/GuidelinesinFinland_EnglishVersion.pdf. Accessed July 23, 2011.

75. Pharmaceuticals Pricing Board: The expert group of the Pharmaceuticals Pricing Board. Helsinki, Finland: Ministry of Social Affairs and Health; 2010. Available from: http://www.stm.fi/en/ministry/boards/ pharmaboard/expert. Accessed July 23, 2011.

76. Ministry of Social Affairs and Health, Finland. Decree of the Ministry of Social Affairs and Health on applications and price notifications made to the Pharmaceuticals Pricing Board. Helsinki, Finland: Ministry of Social Affairs and Health, Finland; 2009. Available from: http://www. ispor.org/PEguidelines/source/GuidelinesinFinland_EnglishVersion. pdf. Accessed July 23, 2011.

77. Becker C. Few details on DRG revamp. The CMS may reveal portions of new system in April. Modern Healthc. 2006;11:12.

78. Falissard B, Izard V, Xerri B, Bouvenot G, Meyer F, Degos L. Relative effectiveness assessment of listed drugs (REAL): A new method for an early comparison of the effectiveness of approved health technologies. Int J Technol Assess Health Care. 2010;26:124-130.

79. Weill C, Banta D. Development of health technology assessment in France. Int J Technol Assess Health Care. 2009;25 Suppl 1:108-111.

80. Chicoye A, Chhabra A. ISPOR global health care systems road map: France - Pharmaceuticals. Lawrenceville, NJ: International Society for Pharmacoeconomics and Outcomes Research (ISPOR); 2009. Available from: http://www.ispor.org/htaroadmaps/France.asp. Accessed July 23, 2011.

81. Pharmaceutical pricing and reimbursement information: Germany. Vienna, Austria: Pharmaceutical Pricing and Reimbursement Information; 2008. Available from: http://ppri.oebig.at/Downloads/Results/ Germany_PPRI_2008.pdf. Accessed July 23, 2011.

82. Paris V, Docteur E. Pharmaceutical pricing and reimbursement policies in Germany [OECD Health Working Papers No. 39]. Paris, France: Organisation for Economic Co-operation and Development; 2008. Available from: http://www.oecd.org/dataoecd/6/57/41586814.pdf. Accessed July 23, 2011. 
83. Fricke FU, Dauben HP. Health technology assessment: A perspective from Germany. Value Health. 2009;12 Supp1 2:S20-S27.

84. Sorenson C. The role of HTA in coverage and pricing decisions: A crosscountry comparison. Euro Observer: The Health Policy Bulletin of the European Observatory on Health Systems and Policies. 2009;11:1-12. Available from: http://www.euro.who.int/_data/assets/pdf_file/0019/80335/EuroObserver_spring2009.pdf. Accessed July 23, 2011.

85. Pricing [Greece]. In: Surveying, assessing and analysing the pharmaceutical sector in the $25 \mathrm{EU}$ member states. Luxembourg: Osterreichisches Bundesinstitut fur Gesundheitswesen for the European Commission; 2006. Available from: http://ec.europa.eu/competition/mergers/studies_reports/oebig.pdf. Accessed July 23, 2011.

86. National Organization for Medicines. Athens, Greece: National Organization for Medicines; 2011. Available from: http://www.eof.gr/web/ guest/structure. Accessed July 23, 2011.

87. International Society for Pharmacoeconomics and Outcomes Research global health care systems road map: Greece. Lawrenceville, NJ: International Society for Pharmacoeconomics and Outcomes Research; 2008. Available from: http://www.ispor.org/HTARoadMaps/Greece. asp. Accessed July 23, 2011.

88. Gaal P. Health care systems in transition: Hungary. Brussels, Belgium: European Observatory on Health Care Systems; 2004. Available from: http://www.euro.who.int/_data/assets/pdf_file/0008/80783/E84926. pdf. Accessed July 23, 2011.

89. Gulacsi L, David T, Dozsa C. Pricing and reimbursement of drugs and medical devices in Hungary. Eur J Health Econ. 2002;3:271-278.

90. Gulacsi L, Brodszky V, Pentek M, Varga S, Vas G, Boncz I. History of health technology assessment in Hungary. Int J Technol Assess Health Care. 2009;25 Suppl 1:120-126.

91. Tilson L, O'Leary A, Usher C, Barry M. Pharmacoeconomic evaluation in Ireland: A review of the process. Pharmacoeconomics. 2010;28:307-322.

92. Barry M. Economies in drug usage in the Irish healthcare setting. Dublin, Ireland: Department of Health and Children; 2009. Available from: http://www.dohc.ie/publications/pdf/economies_drug_usage. pdf?direct $=1$. Accessed July 23, 2011.

93. Coughlan JJ, Fortescue-Webb D, Heaney R, Judge G, Tilson L, Barry M. ISPOR global health care systems road map: Ireland - Pharmaceutical. Lawrenceville, NJ: International Society for Pharmacoeconomics and Outcomes Research; 2009. Available from: http://www.ispor.org/ HTARoadMaps/Ireland.asp. Accessed July 23, 2011.

94. Garattini L. Pricing and reimbursement policies in Italy: Current and future trends. In: Garau M, Mestre-Ferrandiz J, editors. European Medicines Pricing and Reimbursement. Milton Keynes, UK: Radcliffe Publishing; 2007. Available from: http://www.radcliffe-oxford.com/ books/samplechapter/184X/Garau_CHPT4-65cf3e00rdz.pdf. Accessed July 23, 2011.

95. Folino-Gallo P, Montilla S, Bruzzone M, Martini N. Pricing and reimbursement of pharmaceuticals in Italy. Eur J Health Econ. 2008;9:305-310.

96. Impact of HTA on policy: Examples from INAHTA members. Stockholm, Sweden: International Network of Agencies for Health Technology Assessment; 2001. Available from: http://www.inahta.org/upload/ About\%20INAHTA/Survey_HTA_Policy_Oct2001.pdf. Accessed July 23, 2011.

97. Fattore G, Jommi C. The last decade of Italian pharmaceutical policy: Instability or consolidation? Pharmacoeconomics. 2008;26:5-15.

98. Johnsen JR. Health systems in transition: Norway. Copenhagen: World Health Organization Regional Office for Europe on behalf of the European Observatory on Health Systems and Policies; 2006. Available from: http://www.euro.who.int/_data/assets/pdf_file/0005/95144/E88821. pdf. Accessed July 23, 2011.

99. Kuszewski K, Gericke C. Health systems in transition: Poland [Health Systems in Transition 2005;7(5)]. Brussels, Belgium: European Observatory on Health Care Systems; 2005. Available from: http://www.euro. who.int/_data/assets/pdf_file/0011/95159/E88670.pdf. Accessed July 23, 2011.
100. ISPOR global health care systems road map: Poland - reimbursement process. Lawrenceville, NJ: International Society for Pharmacoeconomics and Outcomes Research; 2008. Available from: http://www. ispor.org/HTARoadMaps/Poland.asp. Accessed July 23, 2011.

101. Alves da Silva E, Gouveia Pinto C, Sampaio C, Pereira JA, Drummond M, Trindade R. Guidelines for economic drug evaluation studies. Lisbon, Portugal: Autoridade Nacional do Medicamento e Produtos de Saude; 1998. Available from: http://www.infarmed.pt/portal/page/portal/INFARMED/ ENGLISH/PCAEC04_vering.pdf. Accessed July 23, 2011.

102. Mazag J, Segec A. Pharmaceutical pricing and reimbursement information: Slovakia [Pharmaceutical Pricing and Reimbursement Information]. Vienna, Austria. European Commission, Health and Consumer Protection Directorate-General; Austrian Ministry of Health, Family and Youth; 2007. Available from: http://ppri.oebig.at/Downloads/ Results/Slovakia_PPRI_2007.pdf. Accessed July 23, 2011.

103. Hall PS, McCabe C, Brown JM, Cameron DA. Health economics in drug development: Efficient research to inform healthcare funding decisions. Eur J Cancer. 2010;46:2674-2680.

104. Kohli H, Tannahill A. NICE guidance in the Scottish context. Scott Med J. 2009;54:35-38. Available from: http://www.smj.org.uk/0209/ pdfs/Original\%20Kohli\%20and\%20Tannahill.pdf. Accessed July 23, 2011.

105. Tomek D, Psenkova M, Hanzelova M. Reimbursement of innovative drugs in Slovakia - pharmacoeconomics of agomelatin in depression. Value Health. 2009;12:A364-A365.

106. Kalo Z, Docteur E, Moise P. Pharmaceutical pricing and reimbursement policies in Slovakia [OECD Health Working Paper No. 31]. Paris, France: Organisation for Economic Co-operation and Development; 2008. Available from: http://www.oecd.org/dataoecd/14/40/40177050. pdf. Accessed July 23, 2011.

107. Szalay T, Pazitny P, Szalayova A, et al. Slovakia: Health system review [Health Systems in Transition 2011;13(2)]. Copenhagen, Denmark: World Health Organisation Regional Office for Europe. European Observatory on Health Systems and Policies.; 2011. Available from: http://www.euro.who.int/_data/assets/pdf_file/0004/140593/e94972. pdf. Accessed July 23, 2011.

108. Vogler S, Espin J, Habl C. Pharmaceutical pricing and reimbursement information (PPRI) - new PPRI analysis including Spain. Pharm Pol Law. 2009;11:213-234. Available from: http:// ppri.oebig.at/Downloads/Publications/Article_PPRI_Spain_ PharmaceuticalPolicyAndLaw_2009.pdf. Accessed July 23, 2011.

109. Persson U, Willis M, Odegaard K. A case study of ex ante, value-based price and reimbursement decision-making: TLV and rimonabant in Sweden. Eur J Health Econ. 2010;11:195-203.

110. Moise P, Docteur E. Pharmaceutical pricing and reimbursement policies in Sweden [OECD Health Working Papers, No. 28]. Paris, France: Organisation for Economic Co-operation and Development (OECD); 2007. Available from: http://www.oecd.org/dataoecd/63/17/40699881. pdf. Accessed July 23, 2011.

111. Pharmaceutical Pricing and Reimbursement Information: Sweden. Vienna, Austria: PPRI - Pharmaceutical Pricing and Reimbursement Information; 2007. Available from: http://ppri.oebig.at/Downloads/ Results/Sweden_PPRI_2007.pdf. Accessed July 23, 2011.

112. Erntoft S. ISPOR global health care systems road map: Sweden - pharmaceutical. Lawrenceville, NJ: International Society for Pharmacoeconomics and Outcomes Research; 2009. Available from: http://www.ispor.org/HTARoadMaps/Sweden.asp. Accessed July 23, 2011.

113. Gress S, Niebuhr D, May W, Wasem J. Reform of prescription drug reimbursement and pricing in the German social health insurance market: A comparison of three scenarios. Pharmacoeconomics. 2007;25:443-454.

114. Paris V, Docteur E. Pharmaceutical pricing and reimbursement policies in Switzerland [OECD Health Working Papers, No. 27]. Paris, France: Organisation for Economic Co-operation and Development (OECD); 2007. Available from: http://www.oecd.org/dataoecd/54/42/38868953. pdf. Accessed July 23, 2011. 
115. European Observatory on Health Care Systems. Health care systems in transition: Switzerland. Brussels, Belgium: European Observatory on Health Care Systems; 2000. Available from: http:/www.euro.who. int/_data/assets/pdf_file/0003/96411/E68670.pdf. Accessed July 23, 2011.

116. van der Meijden C, Grahlmann C. Dutch assessment procedures for the reimbursement of outpatient medicines. Diemen, The Netherlands: Ministry of Health, Welfare and Sport/College voor zorgverzekeringen; 2010. Available from: http://www.cvz.nl/binaries/live/ cvzinternet/hst_content/nl/documenten/rubriek+zorgpakket/cfh/ assessment-outpatient-medicines.pdf. Accessed July 23, 2011.

117. Stolk EA, de Bont A, van Halteren AR, Bijlmer RJ, Poley MJ. Role of health technology assessment in shaping the benefits package in The Netherlands. Expert Rev Pharmacoecon Outcomes Res. 2009;9:85-94.

118. ISPOR global health care systems road map: The Netherlands. Lawrenceville, NJ: International Society for Pharmacoeconomics and Outcomes Research; 2007. Available from: http:/www.ispor.org/ HTARoadMaps/Netherlands.asp. Accessed July 23, 2011.

119. Heemstra HE. Variations in access and use of orphan drugs among EU member states. EJHP Practice. 2010;16:25-27. Available from: http://www.eahp.eu/EJHP/EJHP-Practice/Issue-4-2010/Cover-Story/ Variations-in-access-and-use-of-orphan-drugs-among-EU-MemberStates. Accessed July 23, 2011.

120. ISPOR global health care systems road map: United Kingdom (England and Wales) - reimbursement process. Lawrenceville, NJ: International Society for Pharmacoeconomics and Outcomes Research; 2008. Available from: http:/www.ispor.org/htaroadmaps/UK.asp. Accessed July 23, 2011.

121. The Danish Health Act/legislation. Copenhagen, Denmark: Danish Medicines Agency; 2010. Available from: http://laegemiddelstyrelsen. $\mathrm{dk} / \mathrm{en} /$ service-menu/legislation/the-danish-health-act. Accessed July 23, 2011.

122. Mossialos E, Srivastava D. Pharmaceutical policies in Finland: Challenges and opportunities [Observatory Studies Series No. 10]. Copenhagen, Denmark: World Health Organisation. Regional Office for Europe on behalf of the European Observatory on Health Systems and Policies; 2008. Available from: http://www.euro.who.int/_data/ assets/pdf_file/0020/80651/E91239.pdf. Accessed July 23, 2011.

123. Perleth M, Gibis B, Gohlen B. A short history of health technology assessment in Germany. Int J Technol Assess Health Care. 2009; 25 Suppl 1:112-119.

124. Holtorf AP, Matuszewski K, Nuijten M, Vauth C. ISPOR global health care systems road map: Germany. Lawrenceville, NJ: International Society for Pharmacoeconomics and Outcomes Research; 2009. Available from: http://www.ispor.org/htaroadmaps/Germany.asp. Accessed July 23, 2011.

125. Tilson L, Barry M. Recent developments in pharmacoeconomic evaluation in Ireland. Expert Rev Pharmacoecon Outcomes Res. 2010;10:221-224.

126. Pricing and reimbursement. Rome, Italy: Agenzia Italiana del Farmaco; 2010. Available from: http://www.agenziafarmaco.it/en/content/ pricing-and-reimbursement. Accessed July 23, 2011.

127. Agencja Oceny Technologii Medycznych. Warsaw, Poland: Agencja Oceny Technologii Medycznych; 2011. Available from: http:/www aotm.gov.pl/. Accessed July 23, 2011.

128. Scottish Medicines Consortium. Scottish Medicines Consortium; 2010. Available from: http://www.scottishmedicines.org.uk/smc/22. html. Accessed July 23, 2011.

129. Wilking N, Jonsson B. A pan-European comparison regarding patient access to cancer drugs. Stockholm, Sweden: Karolinska Institutet; 2006. Available from: http://ki.se/content/1/c4/33/52/Cancer_Report. pdf. Accessed July 23, 2011.

130. Informace k pravidelne revizi uhrad. Prague, Czechoslovakia: Statni Ustav pro Kontrolu Leciv (SUKL); 2009. Available from: http://www.sukl.cz leciva/informace-k-pravidelne-revizi-uhrad. Accessed July 23, 2011.

131. Tomek D, Bielik J. Legislative aspects of health technology assessment in Slovakia. Value Health. 2009;12:A87.
132. ISPOR global health care systems road map: Spain - Pharmaceutical. Lawrenceville, NJ: International Society for Pharmacoeconomics and Outcomes Research; 2009. Available from: http://www.ispor.org/ HTARoadMaps/Spain.asp. Accessed July 23, 2011.

133. Pharmaceutical Pricing and Reimbursement Information: Sweden. Vienna, Austria: Pharmaceutical Pricing and Reimbursement Information; 2007. Available from: http://ppri.oebig.at/Downloads/Results/ Sweden_PPRI_2007.pdf. Accessed July 23, 2011.

134. Working guidelines for the pharmaceutical reimbursement review. Stockholm, Sweden: Tandvards-Och Lakemedelsformansverket (TLV)/the Dental and Pharmaceutical Benefits Agency [formerly the Swedish Pharmaceutical Benefits Board]; 2008. Available from: http:/www.tlv.se/Upload/Genomgangen/guidelines-pharmaceuticalreimbursement.pdf. Accessed July 23, 2011.

135. Reimbursement review. Stockholm, Sweden: Tandvards Och Lakemedelsformansverket (TLV) [The Swedish Pharmaceutical Benefits Board]; 2009. Available from: http://www.tlv.se/in-english/ reimbursement-review/. Accessed July 23, 2011.

136. Glenngard AH, Hjalte F, Svensson M, Anell A, Bankauskaite V. Health systems in transition: Sweden. Copenhagen, Denmark: World Health Organisation Regional Office for Europe on behalf of the European Observatory on Health Systems and Policies; 2005. Available from: http://www.euro.who.int/_data/assets/pdf_file/0010/96409/E88669. pdf. Accessed July 23, 2011.

137. Gress S, Niebuhr D, Rothgang H, Wasem J. Criteria and procedures for determining benefit packages in health care. A comparative perspective. Health Policy. 2005;73:78-91.

138. Dolezal T. Pricing and reimbursement in Czech Republic ... road to HTA? Lawrenceville, NJ: International Society for Pharmacoeconomics and Outcomes Research; 2008. Available from: http://www. google.ca/url? sa=t\&source $=$ web $\& \mathrm{~cd}=2 \&$ ved $=0 \mathrm{CBwQFjAB \& url}=\mathrm{ht}$ tp $\% 3 \mathrm{~A} \% 2 \mathrm{~F} \% 2 \mathrm{Fwww}$.isporserbia.com $\% 2 \mathrm{Fdocs} \% 2 \mathrm{Ffirst} \% 2 \mathrm{FMarch}$ 10\%2F02.ppt\&ei=QgTkTfnFDqvQiAL017WoBg\&usg=AFQjCNEc RD0RWYovvKcnIEV-017m4bG0ow. Accessed July 23,2011.

139. Pharmacoeconomic analysis. Tallinn, Estonia: Estonian Health Insurance Fund; 2002. Available from: http://www.haigekassa.ee/eng/ health-insurance-in-estonia/medicinal-products/pharmacoeconomicanalysis. Accessed July 23, 2011.

140. Aaviskoo A, Saluse J, Palm E. Scientific community leads HTA development [Health Policy Monitor]. 2009. Available from: http:// www.hpm.org/survey/ee/a14/2. Accessed July 23, 2011.

141. Daniels N, Sabin J. Limits to health care: Fair procedures, democratic deliberation, and the legitimacy problem for insurers. Philos Public Aff. 1997;26:303-350.

142. Bekkering GE, Kleijnen J. Procedures and methods of benefit assessments for medicines in Germany. Eur J Health Econ. 2008;9 Suppl 1: 5-29

143. Martikainen J, Rajaniemi S. Drug reimbursement systems in EU member states, Iceland and Norway: France. In. 54. Helsinki: The Social Insurance Institution; 2002. Available from: http://www.kela. fi/in/internet/english.nsf/NET/050303135141PN. Accessed July 23, 2011.

144. Paris V, Docteur E. Pharmaceutical pricing and reimbursement policies in Germany [OECD Health Working Papers, No. 39]. Paris: Organisation for Economic Co-operation and Development (OECD); 2008. Available from: http://www.oecd.org/dataoecd/6/57/41586814.pdf. Accessed July 23, 2011.

145. Yfantopoulos J. Pharmaceutical pricing and reimbursement reforms in Greece. Eur J Health Econ. 2008;9:87-97.

146. Irish healthcare technology assessment guidelines. version 1. Dublin, Ireland: National Centre for Pharmacoeconomics (NCPE) in Ireland; 2000. Available from: http://www.ncpe.ie/contact.php. Accessed July 23, 2011.

147. Guidelines for the economic evaluation of health technologies in Ireland. Dublin, Ireland: Health Information and Quality Authority; 2010. Available from: http:/www.hiqa.ie/system/files/HTA Economic_Guidelines_2010.pdf. Accessed July 23, 2011. 
148. Pharmacoeconomic guidelines around the world: Italy. Lawrenceville, NJ: International Society for Pharmacoeconomics and Outcomes Research; 2010. Available from: http://www.ispor.org/PEguidelines/ countrydet.asp? $\mathrm{c}=13 \& \mathrm{t}=4$. Accessed July 23, 2011.

149. Application standard for acceptance to the drug reimbursement scheme; pursuant to Article 9 of the regulation on reimbursement of crucial drug costs. [Oslo]: Statens legemiddelverk/Norwegian Medicines Agency; 2005. Available from: http://www.legemiddelverket. no/templates/InterPage_25665.aspx. Accessed July 23, 2011.

150. Norwegian guidelines for pharmacoeconomic analysis in connection with applications for reimbursement. Oslo, Norway: Statens legemiddelverk/Norwegian Medicines Agency; 2005. Available from: http:// www.legemiddelverket.no/templates/InterPage_25644.aspx. Accessed July 23, 2011.

151. Polish guidelines for conducting pharmacoeconomic evaluations. Lawrenceville, NJ: International Society for Pharmacoeconomics and Outcomes Research; 2010. Available from: http://www.ispor. org/PEguidelines/source/Polish-Guidelines-for-Conducting-Pharma coeconomic-Evaluations_2010.pdf. Accessed July 23, 2011.

152. Pharmacoeconomic guidelines around the world: Slovak Republic. Lawrenceville, NJ: International Society for Pharmacoeconomics and Outcomes Research; 2011. Available from: http://www. ispor.org/peguidelines/countrydet. $a s p ? c=35 \& t=1$. Accessed July 23, 2011.

153. General guidelines for economic evaluations from the Pharmaceutical Benefits Board (LFNAR 2003:2). Stockholm, Sweden: Pharmaceutical Benefits Board; 2003. Available from: http://www.ispor.org/peguidelines/ source/Guidelines_in_Sweden.pdf. Accessed July 23, 2011.

154. Vegter S, Rozenbaum MH, Postema R, Tolley K, Postma MJ. Review of regulatory recommendations for orphan drug submissions in The Netherlands and Scotland: Focus on the underlying pharmacoeconomic evaluations. Clin Ther. 2010;32:1651-1661.

155. Stolk EA, Poley MJ. Criteria for determining a basic health services package. Recent developments in The Netherlands. Eur J Health Econ. $2005 ; 6: 2-7$.

156. Stolk EA, de BA, van Halteren AR, Bijlmer RJ, Poley MJ. Role of health technology assessment in shaping the benefits package in The Netherlands. Expert Rev Pharmacoecon Outcomes Res 2009;9: 85-94.

157. Single technology appraisal (STA): Specification for manufacturer/ sponsor submission of evidence. London, UK: National Institute for Health and Clinical Excellence; 2009. Available from: http://www.nice. org.uk/media/59C/B3/SpecificationForManufacturerSponsorSubmissionEvidenceJune2010.doc. Accessed July 23, 2011.

158. Lloyd A, Wild D, Gallop K, Cowell W. Reimbursement agency requirements for health related quality-of-life data: A case study. Expert Rev Pharmacoecon Outcomes Res. 2009;9: 527-537.

159. Niemietz KPMP. A healthy market? Health technology assessment in the UK and Germany [Stockholm Network Papers on Health Technology Assessment. Paper No. 2]. Stockholm, Sweden: Stockholm Network; 2007. Available from: http://www.stockholmnetwork.org/downloads/publications/HTA3_2.pdf. Accessed July 23, 2011.

160. Barros PP. Pharmaceutical policies in European countries. Adv Health Econ Health Serv Res. 2010;22:3-27.

161. Annex to the decree by the Ministry of Social Affairs and Health on applications for a reasonable wholesale price, on special reimbursement status for a medicinal product, and on the documentation to be attached to the application (1393/2003). Helsinki, Finland: Finland Ministry of Social Affairs and Health; 2003. Available from: http://www.stm. fi/c/document_library/get_file?folderId=71837\&name=DLFE-7603. pdf. Accessed July 23, 2011.

162. Medical device assessment in France: Guidebook. Cedex, France: Haute Autorite de Sante; 2009. Available from: http://www.has-sante. fr/portail/upload/docs/application/pdf/2010-03/guide_dm_gb_050310. pdf. Accessed July 23, 2011.
163. Office of Health Technology Assessment of the National Institute for Strategic Health Research. Budapest, Hungary: National Institute for Strategic Health Research; 2011. Available from: http://www.eski.hu/ new3/technologia_en/technologia_en.php. Accessed July 23, 2011.

164. Brodszky V, Orlewska E, Pentek M, Karpati K, Skoupa J, Gulacsi L. Challenges in economic evaluation of new drugs: Experience with rituximab in Hungary. Med Sci Monit. 2010;16:SR1-SR5.

165. Barry M, Tilson L. Recent developments in pricing and reimbursement of medicines in Ireland. Expert Rev Pharmacoecon Outcomes Res. 2007;7:605-611. Available from: http://www.expert-reviews.com/ doi/pdf/10.1586/14737167.7.6.605. Accessed July 23, 2011.

166. Kozierkiewicz A, Trabka W, Romaszewski A, Gajda K, Gilewski D. Definition of the "health benefit basket" in Poland. Eur J Health Econ. 2005;6 Suppl 1:58-65. Available from: http://www.ncbi. nlm.nih.gov/pmc/articles/PMC1388086/?tool=pubmed. Accessed July 23, 2011.

167. Orlewska E, Mierzejewski P. Project of Polish guidelines for conducting pharmacoeconomic evaluations in comparison to international health economic guidelines. Eur J Health Econ. 2003;4:296-303.

168. Pharmacoeconomic guidelines around the world: Scotland. Lawrenceville, NJ: International Society for Pharmacoeconomics and Outcomes Research; 2010. Available from: http://www.ispor. org/PEguidelines/countrydet.asp? $\mathrm{c}=19 \& \mathrm{t}=2$. Accessed July 15, 2011.

169. Visnansky M. HTA and health care decisions in Slovakia. Lawrenceville, NJ:International Society for Pharmacoeconomics and Outcomes Research; 2010. Available from: http://www.ispor.org/regional_chapters/Slovakia/ documents/ISPOR_HTA_and_HC_Dcisions_in_SK_HTAC_112010. pdf. Accessed July 23, 2011.

170. Guideline: the Ministry of Health of the Slovak Republic no. 343/2008 Z. z. the details of pharmaco-economic analysis of drug ... the Ministry of Health of the Slovak Republic no. 210/2008 Z. laws, which provides details on the medico-economic analysis of the medical device when the decree of the Ministry of Health of the Slovak Republic no. $149 / 2009$ Z. z. the details of medico-economic analysis of dietary food for the implementation of pharmaco-economic analysis of drug; medico-econoic analysis of the medical device and medico-economic analysis of the dietary food. Bratislava, Slovakia: Ministerstva zdravotnictva Slovenskej republiky; 2009. Available from: http://www2. health.gov.sk/redsys/rsi.nsf/0/4399FF0A33156D1CC1256FAF002B 94DE?OpenDocument. Accessed July 23, 2011.

171. Duran A, Lara JL, van Waveren M. Spain: Health system review [Health Systems in Transition]. Copenhagen, Denmark: European Observatory on Health Care Systems, World Health Organization Regional Office for Europe; 2006. Available from: http://www. euro.who.int/en/home/projects/observatory/publications/healthsystem-profiles-hits/full-list-of-hits/spain-hit-2007. Accessed July 23, 2011.

172. Muller KR. ISPOR global health care systems road map: Switzerland - Pharmaceutical. Lawrenceville, NJ: International Society for Pharmacoeconomics and Outcomes Research (ISPOR); 2011. Available from: http://www.ispor.org/htaroadmaps/SwitzerlandPH. asp. Accessed July 23, 2011.

173. van Nooten F, van Agthoven M. Mandatory pharmacoeconomic studies in the Dutch reimbursement setting. Institute for Medical Technology Assessment newsletter. 2005;3:1-3. Available from: http://www.bmg. eur.nl/fileadmin/ASSETS/bmg/english/iMTA/Publications/Newslet ter/imta_newsletter_3_1.pdf. Accessed July 23, 2011.

174. All Wales Medicines Strategy Group: Structure of appraisal. Vale of Glamorgan, Wales: All Wales Medicines Strategy Group; 2007. Available from: $\mathrm{http}: / / \mathrm{www} . w a l e s . n h s . u k /$ sites $3 /$ home.cfm?orgid=371. Accessed July 23, 2011.

175. INAMI - medicaments. Brussels, Belgium: I National Institute for Health and Disability Insurance; 2011. Available from: http:// www.inami.fgov.be/drug/fr/drugs/index.htm\#2. Accessed July 23, 2011. 
176. Sandmann FG. Framework of decision making regarding the benefit package in the Czech Republic. In: Decision making on the inclusion of new provisions in the benefit package: A comparative study between the Netherlands and the Czech Republic (with a focus on the role of value for money considerations in pharmaceutical reimbursement decision making). Enschede, The Netherlands: University of Twente. School of Management and Governance; 2010. Available from: http:// www.utwente.nl/mb/htsr/education/completed\%20assignments/ Sandmann.pdf. Accessed July 23, 2011.

177. Petrikova A, Dolezal T, Lamka J, Klimes J. Description of the pricing and reimbursement system in the Czech Republic. Prague, Czechoslovakia: Institute of Health Economics and Technology Assessment; 2010. Available from: http://www.iheta.org/ext/files/27/ Poster_ISPOR_PR_CZ.pdf. Accessed July 23, 2011.

178. Davidova J, Praznovcova L, Lundborg CS. Pricing and reimbursement of pharmaceuticals in the Czech Republic and Sweden. Pharm World Sci. 2008;30:57-64.

179. Davidova J, Ivanovic N, Praznovcova L. Participation in pharmaceutical costs and seniors' access to medicines in the Czech Republic. Cent Eur J Public Health. 2008;16:26-28. Available from: http://www1.szu.cz/svi/cejph/archiv/2008-1-06-full.pdf. Accessed July 23, 2011

180. Spacilova L, Petrelli F, Grappasonni I, Scuri S. Health care system in the Czech Republic. Ann Ig. 2007;19:573-581.

181. Mossialos E, Srivastava D. Overview of the pharmaceutical system in Finland. In: Pharmaceutical policies in Finland: challenges and opportunities [Observatory Studies Series No. 10]. Copenhagen, Denmark: World Health Organization; European Observatory on Health Systems and Policies; Ministry of Social Affairs and Health Finland; 2008. Available from: http://www.euro.who.int/__data/assets/ pdf_file/0020/80651/E91239.pdf. Accessed July 23, 2011.

182. Government decree on the Pharmaceuticals Pricing Board. Helsinki, Finland: Finland Ministry of Social Affairs and Health; 2008. Available from: http://www.stm.fi/c/document_library/ get_file?folderId=71837\&name=DLFE-10036.pdf. Accessed July 23, 2011.

183. Strandberg-Larsen M, Nielsen MB, Vallgarda S, Krasnik A, Vrangbaek K. Denmark: Health system review [Health Systems in Transition 2007;9]. Copenhagen, Denmark: World Health Organisation Regional Office for Europe. European Observatory on Health Care Systems; 2007. Available from: http://www.euro.who.int/_data/ assets/pdf_file/0004/80581/E91190.pdf. Accessed July 23, 2011.

184. Falissard B, Zylberman M, Cucherat M, et al. Real medical benefit assessed by indirect comparison. Therapie. 2009;64:225-232. French.

185. Haute Autorite de Sante. Cedex, France: Haute Autorite de Sante; 2010. Available from: http://www.has-sante.fr. Accessed July 23, 2011.

186. Yfantopoulos J. Pharmaceutical pricing and reimbursement reforms in Greece. Eur J Health Econ. 2008;9:87-97.

187. Rules of procedure of the social insurance inclusion of pharmaceuticals in Hungary. Budapest, Hungary: National Institute for Strategic Health Research. Office of Health Technology Assessment; 2011. Available from: http://www.eski.hu/new3/technologia_en/technologia_en_procedure.php. Accessed July 23, 2011.

188. ISPOR global health care systems road map: Italy - Pharmaceuticals. Lawrenceville, NJ: International Society for Pharmacoeconomics and Outcomes Research (ISPOR); 2011. Available from: http://www.ispor. org/HTARoadMaps/Italy.asp. Accessed July 23, 2011.

189. Godman B, Sakshaug S, Berg C, Wettermark B, Haycox A. Combination of prescribing restrictions and policies to engineer low prices to reduce reimbursement costs. Expert Rev Pharmacoecon Outcomes Res. 2011; 11:121-129.

190. Nizankowski R, Wilk N. From idealistic rookies to a regional leader: The history of health technology assessment in Poland. Int J Technol Assess Health Care. 2009;25 Suppl 1:156-162.
191. Ministerio da Saude: Decreto-Lei no. 48-A/2010. Oeiras, Portugal: Associacao Portuguese de Medicamentos Genencos; 2010. Available from: http://www.apogen.pt/conteudos/uploads/Files/ apogen/PacoteMedicamento_13Maiode2010.pdf. Accessed July 23, 2011.

192. Jansson S. Implementing accountability for reasonableness - the case of pharmaceutical reimbursement in Sweden. Health Econ Policy Law. 2007;2(Pt 2):153-171.

193. Guidelines for pharmacoeconomic research, updated version. Diemen, The Netherlands: College voor Zorgverzekeringen; 2006. Available from: http://www.ispor.org/peguidelines/source/HTAGuidelines NLupdated2006.pdf. Accessed July 23, 2011.

194. Healy P, Pugatch M. Theory versus practice: Discussing the governance of health technology assessment systems. Stockholm, Sweden: Stockholm Network; 2009. Available from: http://www.stockholm-network. org/downloads/publications/Theory_versus_Practice.pdf. Accessed July 23, 2011.

195. Sculpher M. Single technology appraisal at the UK National Institute for Health and clinical excellence: A source of evidence and analysis for decision making internationally. Pharmacoeconomics. 2010;28:347-349.

196. Kennedy I. Appraising the value of innovation and other benefits: A short study for NICE. London, UK: National Institute for Health and Clinical Excellence; 2009. Available from: http:/www.nice.org. uk/media/98F/5C/KennedyStudyFinalReport.pdf. Accessed July 23, 2011.

197. Rawlins MD, Culyer AJ. National Institute for Clinical Excellence and its value judgments. BMJ. 2004;329:224-227.

198. All Wales Medicines Strategy Group: Independent review process. Vale of Glamorgan, Wales: All Wales Medicines Strategy Group; 2007. Available from: http://www.wales.nhs.uk/sites3/Documents/371/ Independent $\% 20$ Review\%20process $\% 20 \_$fina $\% 20$ for $\% 20$ website_. pdf. Accessed July 23, 2011.

199. General method for assessing health technologies. Paris, France: Haute Autorite de Sante, Department of Medical and Surgical Procedures Assessment; 2007. Available from: http://www.has-sante.fr/ portail/upload/docs/application/pdf/general_method_eval_techno.pdf. Accessed July 23, 2011.

200. ISPOR global health care systems road map: Italy - Reimbursement process. Lawrenceville, NJ: International Society for Pharmacoeconomics and Outcomes Research; 2008. Available from: http://www. ispor.org/HTARoadMaps/Italy.asp. Accessed July 23, 2011.

201. Stolk EA, Rutten FF. The "health benefit basket" in the Netherlands. Eur J Health Econ. 2005;Suppl:53-57.

202. Devlin N, Parkin D. Does NICE have a cost-effectiveness threshold and what other factors influence its decisions? A binary choice analysis. Health Econ. 2004;13:437-452.

203. Pharmaceuticals Pricing Board: the Pharmaceuticals Pricing Board and the secretariat. Helsinki, Finland: Ministry of Social Affairs and Health/Social - Och Halsovardsministeriet; 2009. Available from: http://www.stm.fi/en/ministry/boards/pharmaboard/board. Accessed July 23, 2011.

204. Nasser M, Sawicki P. Institute for quality and efficiency in health care: Germany. Issue Brief (Commonw Fund). 2009;57:1-12. Available from: http://www.commonwealthfund.org/ /media/Files/ Publications/Issue\%20Brief/2009/Jul/Chalkidou/1294_Nasser_CER_ Germany_issue_brief_724.pdf. AccessedJuly 23, 2011.

205. Vandoros S, Kanavos P. Pricing, regulation, reimbursement and healthcare budgets. European Cancer Patient Coalition. 2009. Available from http://www.ecpc-online.org/component/docman/doc_download/121sotiri-vandoros-pricing-regulation-reimbursement-and-healthcarebudgets.html?ItemId=127. Accessed July 23, 2011.

206. Persson U, Willis M, Odegaard K. A case study of ex ante, value-based price and reimbursement decision-making: TLV and rimonabant in Sweden. Eur J Health Econ. 2010;11:195-203. 
207. Moise P, Docteur E. Pharmaceutical pricing and reimbursement policies in Sweden [OECD Health Working Papers, No. 28]. Paris, France: Organisation for Economic Co-operation and Development (OECD); 2007. Available from: http://www.oecd.org/dataoecd/63/17/40699881. pdf. Accessed July 23, 2011.

208. Jansson S. Implementing accountability for reasonableness - the case of pharmaceutical reimbursement in Sweden. Health Econ Policy Law. 2007;2(Pt 2):153-171.

209. Willis M, Persson U, Zoellner Y, Gradl B. Reducing uncertainty in value-based pricing using evidence development agreements: The case of continuous intraduodenal infusion of levodopa/ carbidopa (DuodopaR) in Sweden. Appl Health Econ Health Policy. 2010;8:377-386.

210. Stolk P, Schneeweiss S, Leufkens HGM, Heerdink ER. Impact analysis of the discontinuation of reimbursement: The case of oral contraceptives. Contraception. 2008;78:399-404.

211. Schafer W, Kroneman M, Boerma W, et al. The Netherlands: Health system review [Health Systems in Transition]. Copenhagen, Denmark: European Observatory on Health Care Systems, World Health Organization Regional Office for Europe; 2010. Available from: http:// www.euro.who.int/en/home/projects/observatory/publications/healthsystem-profiles-hits/full-list-of-hits/netherlands-hit-2010. Accessed July 23, 2011.
212. Webb DJ. Value-based medicine pricing: NICE work? Lancet. 2011; 377:1552-1553.

213. Kanavos P, Manning J, Taylor D, Schurer W, Checchi K. Implementing value-based pricing for pharmaceuticals in the UK. Final report. London, UK: 2020 Health; 2010. Available from: http://www.2020health. org/2020health/research/vbp-a.html. Accessed July 23, 2011.

214. A new value-based approach to the pricing of branded medicines: A consultation. London, UK: UK Department of Health. Medicines, Pharmacy and Industry Group; 2010. Available from: http://www. dh.gov.uk/en/Consultations/Liveconsultations/DH_122760. Accessed July 23, 2011.

\section{Publish your work in this journal}

ClinicoEconomics \& Outcomes Research is an international, peerreviewed open-access journal focusing on Health Technology Assessment, Pharmacoeconomics and Outcomes Research in the areas of diagnosis, medical devices, and clinical, surgical and pharmacological intervention. The economic impact of health policy and health systems organization also constitute important areas of coverage. The manuscript management system is completely online and includes a very quick and fair peer-review system, which is all easy to use. Visit http://www.dovepress.com/testimonials.php to read real quotes from published authors.

Submit your manuscript here: http://www.dovepress.com/clinicoeconomics-and-outcomes-research-journal 